\title{
Mechanisms of $\beta$-cell dedifferentiation in diabetes: recent findings and future research directions
}

\author{
Mohammed Bensellam ${ }^{1,2}$, Jean-Christophe Jonas ${ }^{2}$ and D Ross Laybutt1,3 \\ ${ }^{1}$ Garvan Institute of Medical Research, Sydney, New South Wales, Australia \\ ¿Université Catholique de Louvain, Institut de Recherche Expérimentale et Clinique, Pôle d'Endocrinologie, Diabète et Nutrition, Brussels, Belgium \\ 3St Vincent's Clinical School, UNSW Sydney, Sydney, New South Wales, Australia \\ Correspondence should be addressed to M Bensellam or D R Laybutt: mohammed.bensellam@uclouvain.be or r.laybutt@garvan.org.au
}

\section{Abstract}

Like all the cells of an organism, pancreatic $\beta$-cells originate from embryonic stem cells through a complex cellular process termed differentiation. Differentiation involves the coordinated and tightly controlled activation/repression of specific effectors and gene clusters in a time-dependent fashion thereby giving rise to particular morphological and functional cellular features. Interestingly, cellular differentiation is not a unidirectional process. Indeed, growing evidence suggests that under certain conditions, mature $\beta$-cells can lose, to various degrees, their differentiated phenotype and cellular identity and regress to a less differentiated or a precursor-like state. This concept is termed dedifferentiation and has been proposed, besides cell death, as a contributing factor to the loss of functional $\beta$-cell mass in diabetes. $\beta$-cell dedifferentiation involves: (1) the downregulation of $\beta$-cell-enriched genes, including key transcription factors, insulin, glucose metabolism genes, protein processing and secretory pathway genes; (2) the concomitant upregulation of genes suppressed or expressed at very low levels in normal $\beta$-cells, the $\beta$-cell forbidden genes; and (3) the likely upregulation of progenitor cell genes. These alterations lead to phenotypic reconfiguration of $\beta$-cells and ultimately defective insulin secretion. While the major role of glucotoxicity in $\beta$-cell dedifferentiation is well established, the precise mechanisms involved are still under investigation. This review highlights the identified molecular mechanisms implicated in $\beta$-cell dedifferentiation including oxidative stress, endoplasmic reticulum (ER) stress, inflammation and hypoxia. It discusses the role of Foxo1, Myc and inhibitor of differentiation proteins and underscores the emerging role of non-coding RNAs.

Finally, it proposes a novel hypothesis of $\beta$-cell dedifferentiation as a potential adaptive mechanism to escape cell death under stress conditions.

\author{
Key Words \\ - $\beta$-cell \\ - dedifferentiation \\ - diabetes \\ - glucotoxicity \\ - islet
}

\section{Introduction}

All the cells of an organism, including pancreatic $\beta$-cells, originate from embryonic stem cells through a complex cellular process termed differentiation (Keller 2005). $\beta$-cell differentiation involves the coordinated and tightly controlled activation/repression of specific transcription factors and downstream gene clusters in a time-dependent manner. These complex signalling events drive the transition from definitive endoderm cells to mature 


\begin{tabular}{l|l|l|l|l|}
$\begin{array}{l}\text { Journal of } \\
\text { Endocrinology }\end{array}$ & M Bensellam et al. & $\begin{array}{l}\beta \text {-cell dedifferentiation in } \\
\text { diabetes }\end{array}$ & $\mathbf{2 3 6 : 2}$ & $\mathbf{R 1 1 0}$ \\
\hline
\end{tabular}

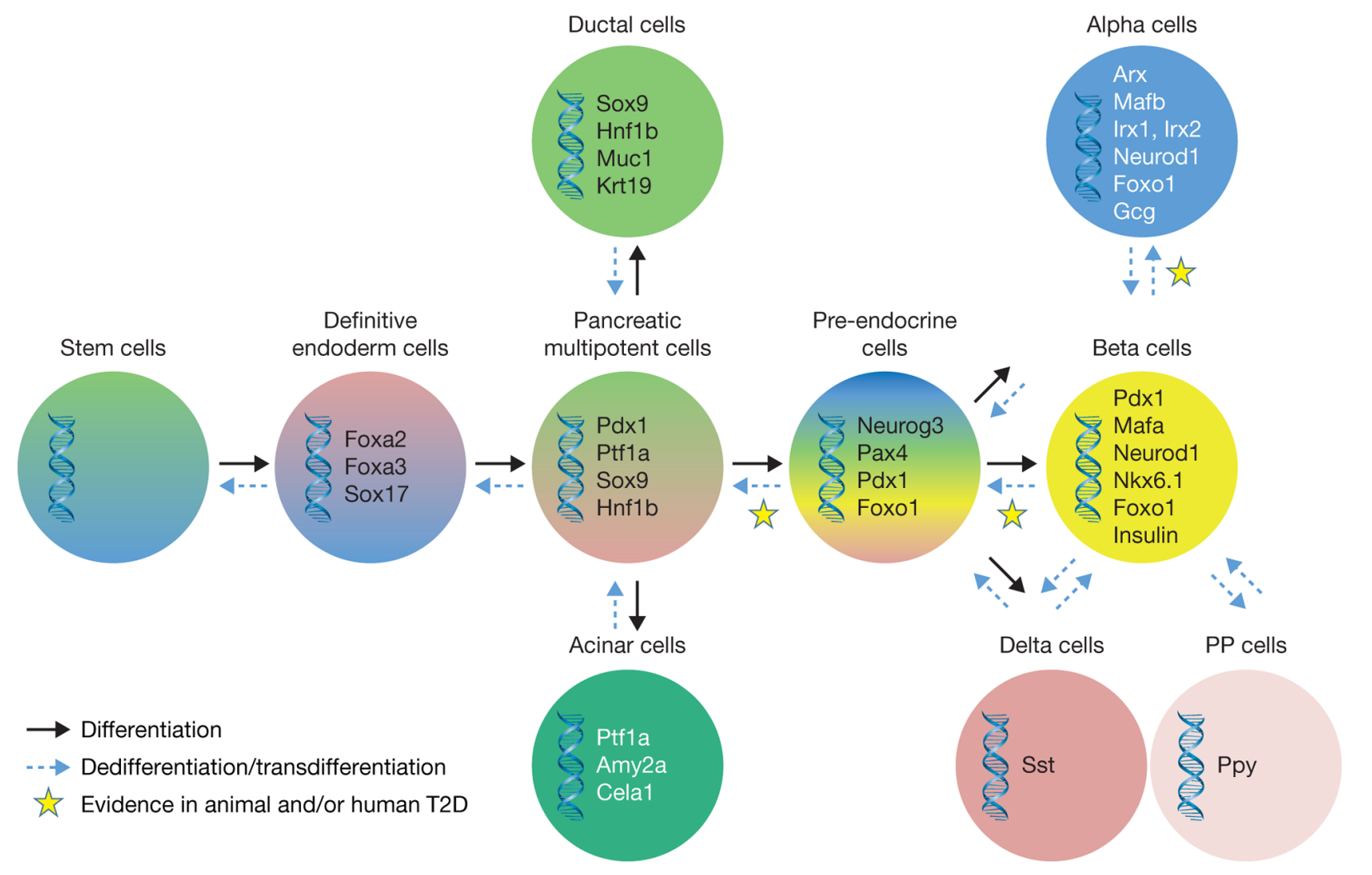

Figure 1

Schematic representation of the process of $\beta$-cell differentiation. This process involves coordinated and tightly controlled activation/repression of specific transcription factors that drive the transition from a stem cell to a mature $\beta$-cell during embryonic development and the postnatal period until weaning. Evidence from animal and human studies suggest that mature $\beta$-cells could regress backwards to a precursor-like stage and/or transdifferentiate into other islet cells in type 2 diabetes.

insulin-secreting $\beta$-cells with the progressive acquisition of specific morphological and functional cellular features (Puri \& Hebrok 2010, Seymour \& Sander 2011, Stanger \& Hebrok 2013) (Fig. 1).

Interestingly, cellular differentiation is not unidirectional. Indeed, growing evidence suggests that under specific conditions, mature $\beta$-cells can lose, to various degrees, their differentiated phenotype and cellular identity and regress to a less differentiated or even a precursor-like state (Fig. 1). This concept, termed dedifferentiation, has been implicated in the pathogenesis of diabetes (Weir et al. 2013). Several in vivo studies in animal models and in humans over the last two decades suggest that, in addition to cell death (Butler et al. 2003, Jurgens et al. 2011), dedifferentiation (Jonas et al. 1999, Kjorholt et al. 2005, Talchai et al. 2012, Marselli et al. 2014, Cinti et al. 2016) may be an important contributing factor to the loss of functional $\beta$-cell mass in type 2 diabetes (Sakuraba et al. 2002, Yoon et al. 2003, Deng et al. 2004, Rahier et al. 2008).

() 2018 Society for Endocrinology Published by Bioscientifica Ltd. Printed in Great Britain $\beta$-cell dedifferentiation is manifested by reduced expression of $\beta$-cell-enriched genes, including key transcription factors, insulin, glucose metabolism genes, protein processing and secretory pathway genes and the concomitant upregulation of genes suppressed or expressed at very low levels in normal $\beta$-cells; the so-called $\beta$-cell disallowed or forbidden genes (Bensellam et al. 2012b, Schuit et al. 2012, Rutter et al. 2015, Lemaire et al. 2016, 2017). Moreover, the presence of progenitor cell markers has been observed in the dedifferentiated islets of diabetic animals (Talchai et al. 2012, Wang et al. 2014, Kim-Muller et al. 2016) and even markers of $\alpha$-cells have been detected suggesting the transdifferentiation of $\beta$-cells to $\alpha$-cells in diabetic animals and humans (Spijker et al. 2013, 2015, Brereton et al. 2014, Cinti et al. 2016). These alterations lead to metabolic and structural reconfiguration of $\beta$-cells and ultimately defective insulin secretion. While earlier and recent reports have well established the major role of hyperglycemia and the ensuing glucotoxicity in $\beta$-cell dedifferentiation (Bensellam et al. 2012b), the 
precise molecular mechanisms involved are still under investigation. Understanding these mechanisms opens novel therapeutic horizons to preserve/restore the functional $\beta$-cell mass in diabetes.

In this extensive review, we first highlight the close relationship between the degree of $\beta$-cell differentiation and insulin secretory function. We then describe the known molecular mechanisms involved in $\beta$-cell dedifferentiation in diabetes with a focus on the role of glucotoxicity and its downstream pathways including oxidative stress, endoplasmic reticulum (ER) stress, inflammation and hypoxia. We depict the roles of the transcriptional regulators such as Foxo1, Myc and the inhibitors of differentiation and discuss the role of the failure of adaptive unfolded protein response (UPR). We also discuss the mounting role of non-coding RNAs in $\beta$-cell dedifferentiation. Finally, based on our and others emerging evidence, we propose a novel view of dedifferentiation as a potential adaptive mechanism to escape cell death under stress conditions.

\section{Relationship of $\beta$-cell differentiation to insulin secretory function}

Pancreatic $\beta$-cells play a fundamental role in the maintenance of glucose homeostasis in mammalians. They synthesize and secrete insulin after meals to keep blood glucose levels within a tight range (between 4 and $6 \mathrm{mM}$ in fasting adult humans). Glucose is the major physiological modulator of $\beta$-cell function and undeniable evidence indicates that glucose must be metabolized by $\beta$-cells in order to stimulate insulin secretion (Malaisse et al. 1979, Newgard \& McGarry 1995, Jitrapakdee et al. 2010). Thus, upon a rise in its plasma concentration, glucose rapidly equilibrates across the $\beta$-cell plasma membrane via the high-capacity, low-affinity glucose transporter GLUT2 (also known as SLC2A2) (Thorens 2015). In humans, the high-affinity glucose transporter GLUT1 prevails instead of GLUT2 (De Vos et al. 1995, Ferrer et al. 1995). Nevertheless, in both human and rodent $\beta$-cells, glucose transport exceeds glucose utilization and is therefore not limiting (Newgard 1996). In the cytosol, glucose is then phosphorylated by glucokinase (GCK); a low-affinity type IV hexokinase. GCK regulates the rate of glucose utilization and is therefore considered as the glucose sensor of $\beta$-cells (Matschinsky 2009). Interestingly, $\beta$-cells present the remarkable feature of an almost complete repression of high-affinity type I-III hexokinases to avoid insulin release at low plasma glucose concentrations in the fasted state (Sekine et al. 1994, Schuit et al. 1999). Glucose6-phosphate is then oxidized by glycolysis to generate ATP, NADH and pyruvate. Because $\beta$-cells present another remarkable feature of expressing very low levels of lactate dehydrogenase (LDH) and monocarboxylate transporter (MCT) (Sekine et al. 1994, Ishihara et al. 1999, Zhao et al. 2001, Thorrez et al. 2011), almost all the pyruvate enters mitochondria to provide a substrate for the Krebs cycle (Fig. 2). This particular design also avoids exercise-induced insulin release (Otonkoski et al. 2007). To compensate for the low LDH activity and maintain the glycolytic flux, $\beta$-cells present a third notable characteristic of two highly active mitochondrial membrane electron shuttles: the glycerol-3-phosphate and the malate-aspartate shuttles that couple the regeneration of cytosolic $\mathrm{NAD}^{+}$with the production of NADH or $\mathrm{FADH}_{2}$ in the mitochondria (MacDonald 1981, 1982, Sekine et al. 1994, Eto et al. 1999). This NADH shuttle system allows tight coupling of glycolysis to mitochondrial metabolism (Fig. 2). In the mitochondria, pyruvate is either oxidized to acetyl-CoA $(\sim 50 \%)$ by pyruvate dehydrogenase (PDH) or carboxylated to oxaloacetate $(\sim 50 \%)$ by pyruvate carboxylase (PC) (MacDonald 1993, Khan et al. 1996). The latter enzyme replenishes Krebs cycle intermediates (anaplerosis) to compensate for their removal for biosynthetic purposes (cataplerosis) (Brun et al. 1996, Schuit et al. 1997, Farfari et al. 2000). Pyruvate metabolism in the Krebs cycle generates reducing equivalent $\mathrm{NADH}$ and $\mathrm{FADH}_{2}$ which together with those generated by the mitochondrial shuttles transfer electrons to the respiratory chain to generate ATP (Duchen et al. 1993, Eto et al. 1999) (Fig. 2). The resulting atypical rise in ATP/ADP ratio (Detimary et al. 1996, 1998) leads to the closure of ATP-gated $\mathrm{K}^{+}\left(\mathrm{K}_{\mathrm{ATP}}\right)$ channels, plasma membrane depolarization, opening of voltage-gated $\mathrm{Ca}^{2+}$ channels (VDCC), $\mathrm{Ca}^{2+}$ influx and the elevation of cytosolic free $\mathrm{Ca}^{2+}$ concentration $\left(\left[\mathrm{Ca}^{2+}\right]_{\mathrm{i}}\right)$, which is the triggering signal for insulin secretion (Fig. 2). This sequence of events is referred to as the triggering pathway of glucose-stimulated insulin secretion (GSIS) (Henquin 2011). Besides, glucose can modulate insulin secretion independently from its action on $\mathrm{K}_{\mathrm{ATP}}$ channels by generating signals that amplify the action of $\mathrm{Ca}^{2+}$ on insulin granule exocytosis, provided that $\mathrm{Ca}^{2+}$ influx is already stimulated and $\left[\mathrm{Ca}^{2+}\right]_{\mathrm{i}}$ is high. It is called the metabolic amplifying pathway of GSIS (Henquin 2011). This pathway requires glucose metabolism but the coupling factors have not been identified with certainty with a probable implication of NADPH (Ivarsson et al. 2005, Ferdaoussi et al. 2015) and other effectors (Fig. 2). Moreover, other nutrients (such as free fatty acids 


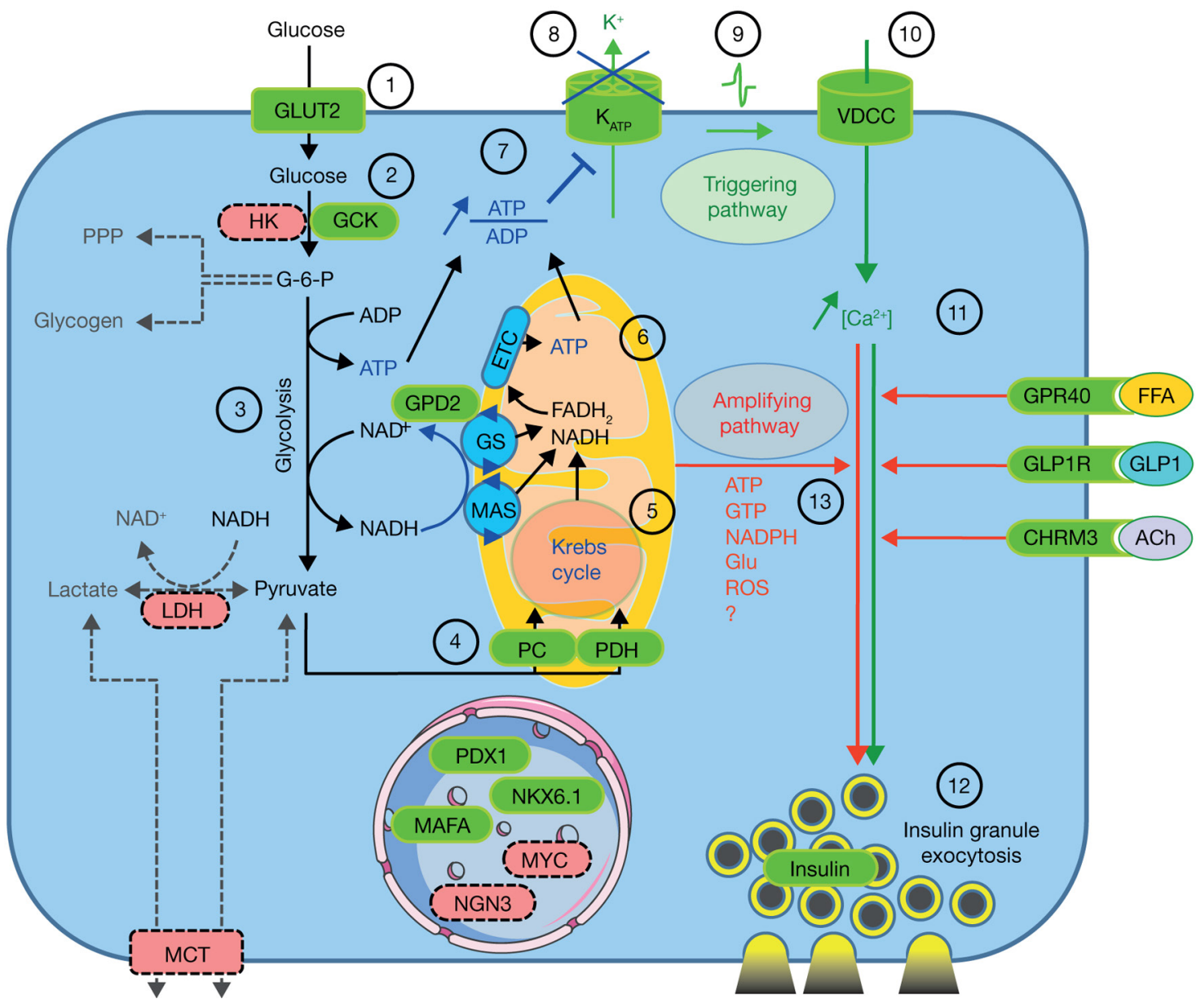

Figure 2

Schematic summary of the stimulus-secretion coupling mechanism in mature differentiated $\beta$-cells with emphasis on key steps and principal components. Upon a rise in its extracellular concentration, glucose rapidly equilibrates across the plasma membrane via the glucose transporter GLUT2 (1) and is phosphorylated by glucokinase (GCK) (2). Glucose-6-phosphate (G-6-P) is further metabolized by glycolysis to generate pyruvate, ATP and NADH (3). The latter requires the mitochondrial shuttles glycerol-3-phosphate (GS) and malate-aspartate (MAS) to regenerate NAD+ to compensate for low lactate dehydrogenase (LDH) activity. Because $\beta$-cells express low levels of monocarboxylate transporter (MCT), pyruvate is channelled to mitochondria where it is transformed into acetyl coenzyme $\mathrm{A}$ and oxaloacetate by pyruvate dehydrogenase (PDH) and pyruvate carboxylase (PC) respectively (4). Acetyl coenzyme A and oxaloacetate are used by the Krebs cycle (5) to generate NADH and FADH2 that, together with those produced by the shuttles, transfer electrons to the electron transport chain (ETC) to generate ATP (6). The latter, together with ATP generated from glycolysis, increases the ATP/ADP ratio (7). This leads to the closure of ATP-dependent $\mathrm{K}^{+}\left(\mathrm{K}_{\mathrm{ATP}}\right)$ channels (8), plasma membrane depolarization (9) and opening of voltage-dependent $\mathrm{Ca}^{2+}$ channels (VDCCs) (10). The ensuing Ca $a^{2+}$ influx and rise in cytosolic free $\mathrm{Ca}^{2+}$ concentration ([Ca $\left.{ }^{2+}\right]$ ) (11) is the triggering signal for insulin secretion (12) and this sequence of events is referred to as the triggering pathway. On the other hand, other metabolic coupling factors generated by glucose metabolism or other nutrient such as free fatty acids in addition to intracellular messengers affected by hormones such as glucagon-like peptide 1 (GLP1) and neurotransmitters such as acetylcholine (Ach) can amplify the effect of $\mathrm{Ca}^{2+}$ on insulin granule exocytosis (13). This is known as the amplifying pathway of insulin secretion. Green arrows: triggering pathway; red arrows: amplifying pathway. Effectors in green: $\beta$-cell-enriched genes; effectors in red: $\beta$-cell forbidden genes.

(Gravena et al. 2002, Itoh et al. 2003)), hormones (such as GLP1 (Campbell \& Drucker 2013)) and neurotransmitters (such as acetylcholine (Gautam et al. 2007, Molina et al. 2014)) can also augment the action of $\mathrm{Ca}^{2+}$ on exocytosis (Fig. 2). The effect of hormones and neurotransmitters is known as the neurohormonal amplification of insulin secretion (Henquin 2011) (Fig. 2).

Adequate $\beta$-cell function relies on a specialized pattern of gene expression. Interestingly, the mature metabolic phenotype of pancreatic $\beta$-cells is acquired only several weeks after birth (Asplund et al. 1969, Pildes et al. 1969, Lavine et al. 1971, Grill et al. 1981). The immaturity of neonatal $\beta$-cells and their poor GSIS have been correlated with low expression of key metabolic genes, high expression of the $\beta$-cell forbidden genes $H k 2, L d h a$ and Mct1 and changes in the expression of specific microRNAs (miRNAs) (Rorsman et al. 1989, Tan et al. 2002, Jermendy et al. 2011, Martens et al. 2014, Jacovetti et al. 2015). 
Dietary differences between neonates and adults, in particular glucose, may drive the maturation of the $\beta$-cell phenotype. Indeed, strong evidence indicates that physiological glucose stimulation is a major regulator of the $\beta$-cell differentiated phenotype (Table 1 ). We and others have shown that the function and survival of rat islets and purified $\beta$-cells are optimally preserved by culture in the presence of $10 \mathrm{mM}$ glucose (G10), whereas marked alteration accompanies culture at lower (G2-5) or higher glucose concentrations (G30; glucotoxicity will be discussed in 'The loss of functional $\beta$-cell differentiation in diabetes: causes and mechanisms' section) (Efanova et al. 1998, Flamez et al. 2002, Khaldi et al. 2004, Bensellam et al. 2009). The beneficial physiological glucose stimulation (G10 vs G2-5) is associated with increased mRNA levels of several critical genes including insulin, components of the triggering pathway of insulin secretion, such as Glut2, subunits of the $\mathrm{K}_{\mathrm{ATP}}$ channel Kir6.2 (also known as Kcnj11) and Sur1 (also known as $A b c c 8$ ) and metabolic genes including glycolysis and Krebs cycle genes, subunits of the mitochondrial electron transport chain, genes implicated in cataplerosis, fatty acid biosynthesis and cholesterol biosynthesis, in parallel with the upregulation of the mRNA levels of the transcription factors Srebp1, Srebp2 and Chrebp (Flamez et al. 2002, Van Lommel et al. 2006, Bensellam et al. 2009) (Table 1). These findings are corroborated by the observation that prolonged fasting (72h) markedly decreases insulin, Glut2, Gck and voltagedependent L-type $\mathrm{Ca}^{2+}$ channel $\alpha 1$ subunit mRNA levels. Interestingly, these alterations were rapidly reversed after refeeding in association with the normalization of $\beta$-cell function (Iwashima et al. 1994).

In addition to metabolic genes, physiological glucose stimulation improves and maintains the $\beta$-cell differentiated phenotype by modulating several stress responses and prosurvival/proapototic effectors and pathways (Van de Casteele et al. 2003, Martens et al. 2005, Hou et al. 2008a, Bensellam et al. 2009, Roma et al. 2012, Sarre et al. 2012). Among them, the UPR occupies a central place (Elouil et al. 2007, Bensellam et al. 2009). $\beta$-cells are highly specialized secretory cells that synthesize large amounts of proinsulin in response to glucose stimulation (Schuit et al. 1988, Ling \& Pipeleers 1996). To cope with this heavy ER load, $\beta$-cells are endowed with a fundamental adaptive response to prevent accumulation of misfolded or unfolded proteins in the ER when client protein load overwhelms the ER folding capacity. UPR activity is orchestrated by three sensors located in the membrane of the ER, namely the pancreatic ER kinase (PERK also known as EIF2AK3), the endoribonuclease/ kinase inositol requiring 1 (IRE1 also known as ERN1) and the activating transcription factor 6 (ATF6). Active PERK phosphorylates the $\alpha$-subunit of the translation initiation factor 2 (eIF $2 \alpha$ ) thereby leading to a transient and global attenuation of protein translation to decrease ER load in parallel with a paradoxical increase in the translation of special transcripts such as ATF4. This transcription factor upregulates the expression of chaperones and antioxidant genes as well as proapoptotic genes like Ddit3 (also known as Chop/Gadd153), Atf3 and Trb3 (also known as Trib3) that contribute to $\beta$-cell death under prolonged or unresolved ER stress. Because eIF2 $\alpha$ can be phosphorylated by kinases other than PERK in response to other types of stress, we will refer to the eIF2 $\alpha$-ATF 4 arm of the UPR by Integrated Stress Response (ISR) if PERK activation has not been demonstrated. Activation of IRE1 leads to the unconventional splicing of Xbp1 pre-mRNA and the ensuing upregulation of active X-Box-binding protein 1 (XBP1s). This key transcription factor, together with active ATF6, stimulates the expression of Xbp1, chaperones, foldases and genes of the ER-associated degradation (ERAD) pathway thereby leading to improved ER folding capacity and enhanced clearance of unfolded proteins from the ER (Schroder \& Kaufman 2005). Interestingly, glucose stimulation exerts opposite effects on the PERKeIF2 $\alpha$-ATF4 and IRE1-XBP1s/ATF6 arms of the UPR. Thus, the PERK-eIF2 $\alpha$-ATF 4 arm is maximally activated at low glucose concentrations (PERK and eIF2 $\alpha$ phosphorylation, upregulation of ATF4 and downstream target genes such as Ddit3), where protein synthesis, ATP levels and $\left[\mathrm{Ca}^{2+}\right]_{\mathrm{ER}}$ are low, while the IRE1-XBP1 arm is maintained at basal level. Glucose stimulation rapidly repressed the ISR and triggered Xbp1 pre-mRNA splicing leading subsequently to the upregulation of XBP1s and a wide array of downstream target genes to face the ER synthetic load (Elouil et al. 2007, Vander Mierde et al. 2007, Gomez et al. 2008, Bensellam et al. 2009, Jonas et al. 2009, Moore et al. 2011). Of note, an inverse relationship between blood glucose levels and eIF2 $\alpha$ phosphorylation in whole pancreatic extracts has been reported in the models of fasting mice and mice receiving an intraperitoneal glucose load (Zhang et al. 2002a). The fine-tuning of this adaptive response is vital for the preservation of the $\beta$-cell differentiated phenotype. Indeed, our and others recent evidence indicated that the failure of adaptive UPR is associated with the progression to diabetes and altered $\beta$-cell differentiation (Herbert \& Laybutt 2016) (see 'The loss of $\beta$-cell differentiation in diabetes: causes and mechanisms' section).

Besides the role of nutrient-induced stimulation of gene expression, the acquisition and maintenance of 


\begin{tabular}{l|l|l|l|} 
Journal of & M Bensellam et al. & $\begin{array}{l}\beta \text {-cell dedifferentiation in } \\
\text { diabetes }\end{array}$ & $\mathbf{2 3 6 : 2}$ \\
Endocrinology & & $\mathbf{R 1 1 4}$
\end{tabular}

Table 1 Physiological glucose stimulation plays a key role in the maintenance of the differentiated $\beta$-cell phenotype.

\begin{tabular}{|c|c|c|c|}
\hline Genes & $\begin{array}{l}\text { Physiological } \\
\text { glucose } \\
\text { stimulation }\end{array}$ & Effect & Models \\
\hline \multicolumn{4}{|l|}{ Islet hormones } \\
\hline \multirow[t]{2}{*}{ Preproinsulin } & G10 vs G2-5 & $\begin{array}{l}\text { Up (also } \\
\text { protein) }\end{array}$ & $\begin{array}{l}\text { Cultured male Wistar rat } \\
\text { islets }(18 \mathrm{~h}) \text { and purified } \beta \\
\text { cells ( } 3-10 \text { days) }\end{array}$ \\
\hline & Fed vs fasted & Up & $\begin{array}{l}\text { Fasted male C57BL6 mice } \\
\text { (overnight) and male } \\
\text { Sprague-Dawley rats }(72 \mathrm{~h})\end{array}$ \\
\hline lapp & G10 vs G2-5 & Up & $\begin{array}{l}\text { Cultured male Wistar rat } \\
\text { islets }(18 \mathrm{~h})\end{array}$ \\
\hline \multicolumn{4}{|l|}{ Transcription factors } \\
\hline$P d x 1$ & G10 vs G5 & Up & $\begin{array}{l}\text { Cultured C57BL6J mouse } \\
\text { islets }(24 \mathrm{~h})\end{array}$ \\
\hline Chrebp & G10 vs G2-5 & Up & $\begin{array}{l}\text { Cultured male Wistar rat } \\
\text { islets }(18 \mathrm{~h})\end{array}$ \\
\hline Srebp1 (Srebf1) & G10 vs G2-5 & Up & $\begin{array}{l}\text { Cultured male Wistar rat } \\
\text { islets }(18 \mathrm{~h}) \text { and purified } \beta \\
\text { cells }(24 \mathrm{~h})\end{array}$ \\
\hline Srebp2 (Srebf2) & G10 vs G2-5 & Up & $\begin{array}{l}\text { Cultured male Wistar rat } \\
\text { islets }(18 \mathrm{~h})\end{array}$ \\
\hline \multicolumn{4}{|l|}{ Glucose transport and metabolism } \\
\hline \multirow[t]{2}{*}{ Glut2 (S/c2a2) } & G10 vs G2-5 & Up & $\begin{array}{l}\text { Cultured male Wistar rat } \\
\text { islets }(18 \mathrm{~h}) \text { and purified } \beta \\
\text { cells }(24-72 \mathrm{~h}) \text { and cultured } \\
\text { C57BL6J mouse islets }(24 \mathrm{~h})\end{array}$ \\
\hline & Fed vs fasted & Up & $\begin{array}{l}\text { Fasted male Sprague-Dawley } \\
\text { rats }(72 \mathrm{~h})\end{array}$ \\
\hline \multirow[t]{2}{*}{ Gck (Hk4) } & G10 vs G2-5 & Up & $\begin{array}{l}\text { Cultured male Wistar rat } \\
\text { islets }(18 \mathrm{~h}) \text { and purified } \beta \\
\text { cells }(72 \mathrm{~h})\end{array}$ \\
\hline & Fed vs fasted & Up & $\begin{array}{l}\text { Fasted male Sprague-Dawley } \\
\text { rats }(72 \mathrm{~h})\end{array}$ \\
\hline Gapdh & G10 vs G2-5 & Up & $\begin{array}{l}\text { Cultured male Wistar rat } \\
\text { islets }(18 \mathrm{~h})\end{array}$ \\
\hline G6pd & G10 vs G2-5 & Up & $\begin{array}{l}\text { Cultured male Wistar rat } \\
\text { islets }(18 \mathrm{~h}) \text { and purified } \beta \\
\text { cells }(24 \mathrm{~h})\end{array}$ \\
\hline $\begin{array}{l}\text { NADH:ubiquinone oxidoreductase subunits } \\
\text { Ndufa1, Ndufa4, Ndufa11, Ndufb4, } \\
\text { Ndufs5, Nd3 }\end{array}$ & G10 vs G2-5 & Up & $\begin{array}{l}\text { Cultured male Wistar rat } \\
\text { islets }(18 \mathrm{~h})\end{array}$ \\
\hline Cycs & G10 vs G2-5 & Up & $\begin{array}{l}\text { Cultured male Wistar rat } \\
\text { islets }(18 \mathrm{~h})\end{array}$ \\
\hline $\begin{array}{l}\text { Cytochrome c oxidase subunits Cox2, Cox3 } \\
\text { (Cytb), Cox5b, Cox6b1, Cox7b, Cox17 }\end{array}$ & G10 vs G2-5 & Up & $\begin{array}{l}\text { Cultured male Wistar rat } \\
\text { islets }(18 \mathrm{~h}) \text { and purified } \beta \\
\text { cells }(24 \mathrm{~h})\end{array}$ \\
\hline $\begin{array}{l}\text { ATP synthase subunits Atp5a1, Atp5e, } \\
\text { Atp5g1, Atp5i, Atp5j, Atp5o }\end{array}$ & G10 vs G2-5 & Up & $\begin{array}{l}\text { Cultured male Wistar rat } \\
\text { islets }(18 \mathrm{~h})\end{array}$ \\
\hline Ant2 (S/c25a5) & G10 vs G2-5 & Up & $\begin{array}{l}\text { Cultured male Wistar rat } \\
\text { islets }(18 \mathrm{~h})\end{array}$ \\
\hline Gpd2 & G10 vs G5 & Up & $\begin{array}{l}\text { Cultured C57BL6J mouse } \\
\text { islets }(24 \mathrm{~h})\end{array}$ \\
\hline \multicolumn{4}{|l|}{ Anaplerosis/cataplerosis } \\
\hline Acly & G10 vs G2-5 & Up & $\begin{array}{l}\text { Cultured male Wistar rat } \\
\text { islets }(18 \mathrm{~h}) \text { and purified } \beta \\
\text { cells }(24 \mathrm{~h})\end{array}$ \\
\hline Mdh1 & G10 vs G2-5 & Up & $\begin{array}{l}\text { Cultured male Wistar rat } \\
\text { islets }(18 \mathrm{~h})\end{array}$ \\
\hline Me1 & G10 vs G2-5 & Up & $\begin{array}{l}\text { Cultured male Wistar rat } \\
\text { islets }(18 \mathrm{~h})\end{array}$ \\
\hline
\end{tabular}

References

Schuit et al. (2002), Van Lommel et al. (2006), Bensellam et al. (2009) Iwashima et al. (1994), Van Lommel et al. (2006)

Bensellam et al. (2009)

(Supplementary Fig. 1)

Bensellam et al. (2009)

Bensellam et al. (2009), Flamez et al. (2002)

Bensellam et al. (2009)

Bensellam et al. (2009), Flamez et al. (2002), Martens \& Pipeleers (2009), (Supplementary Fig. 1)

Iwashima et al. (1994)

Bensellam et al. (2009), Martens \& Pipeleers (2009)

Iwashima et al. (1994)

Bensellam et al. (2009)

Bensellam et al. (2009), Flamez et al. (2002)

Bensellam et al. (2009)

Bensellam et al. (2009)

Bensellam et al. (2009), Flamez et al. (2002)

Bensellam et al. (2009)

Bensellam et al. (2009)

(Supplementary Fig. 1)

Bensellam et al. (2009), Flamez et al. (2002)

Bensellam et al. (2009)

Bensellam et al. (2009) 


\begin{tabular}{l|l|l|l|l|}
$\begin{array}{l}\text { Journal of } \\
\text { Endocrinology }\end{array}$ & M Bensellam et al. & $\begin{array}{l}\beta \text {-cell dedifferentiation in } \\
\text { diabetes }\end{array}$ & $\mathbf{2 3 6 : 2}$ & $\mathbf{R 1 1 5}$ \\
\hline
\end{tabular}

Table 1 Continued.

\begin{tabular}{|c|c|c|c|c|}
\hline Genes & $\begin{array}{l}\text { Physiological } \\
\text { glucose } \\
\text { stimulation }\end{array}$ & Effect & Models & References \\
\hline \multicolumn{5}{|l|}{ Fatty acid metabolism } \\
\hline Fasn & G10 vs G2-5 & Up & $\begin{array}{l}\text { Cultured male Wistar rat } \\
\text { islets }(18 \mathrm{~h}) \text { and purified } \beta \\
\text { cells }(24 \mathrm{~h})\end{array}$ & $\begin{array}{l}\text { Bensellam et al. (2009), } \\
\text { Flamez et al. (2002) }\end{array}$ \\
\hline Hadh & G10 vs G2-5 & Up & $\begin{array}{l}\text { Cultured male Wistar rat } \\
\text { islets }(18 \mathrm{~h}) \text { and purified } \beta \\
\text { cells }(72 \mathrm{~h})\end{array}$ & $\begin{array}{l}\text { Bensellam et al. (2009), } \\
\text { Martens \& Pipeleers } \\
\text { (2009) }\end{array}$ \\
\hline Scd1 & G10 vs G2-5 & Up & $\begin{array}{l}\text { Cultured male Wistar rat } \\
\text { islets }(18 \mathrm{~h})\end{array}$ & Bensellam et al. (2009) \\
\hline $\mathrm{Scd} 2$ & G10 vs G2-5 & Up & $\begin{array}{l}\text { Cultured male Wistar rat } \\
\text { islets }(18 \mathrm{~h}) \text { and purified } \beta \\
\text { cells }(24 \mathrm{~h})\end{array}$ & $\begin{array}{l}\text { Bensellam et al. (2009), } \\
\text { Flamez et al. (2002) }\end{array}$ \\
\hline \multicolumn{5}{|l|}{ Cholesterol metabolism } \\
\hline $\begin{array}{l}\text { Hmgcs1, Hmgcr, Mvd, Idi1, Fdps, Fdft1, } \\
\text { Sqle, Lss, Sc4mol, Nsdhl, Sc5dl, Dhcr7, } \\
\text { Soat1, Scp2, Ldlr }\end{array}$ & G10 vs G2-5 & Up & $\begin{array}{l}\text { Cultured male Wistar rat } \\
\text { islets }(18 \mathrm{~h}) \text { and purified } \beta \\
\text { cells }(24 \mathrm{~h})\end{array}$ & $\begin{array}{l}\text { Bensellam et al. (2009), } \\
\text { Flamez et al. (2002) }\end{array}$ \\
\hline VIdlr & G10 vs G2-5 & Down & $\begin{array}{l}\text { Cultured male Wistar rat } \\
\text { islets }(18 \mathrm{~h}) \text { and purified } \beta \\
\text { cells }(24 \mathrm{~h})\end{array}$ & $\begin{array}{l}\text { Bensellam et al. (2009), } \\
\text { Flamez et al. (2002) }\end{array}$ \\
\hline \multicolumn{5}{|l|}{ Ion channels, pumps and receptors } \\
\hline Kcnj11 (Kir6.2) & G10 vs G3 & Up & $\begin{array}{l}\text { Cultured purified male } \\
\text { Wistar rat } \beta \text { cells ( } 24 \mathrm{~h})\end{array}$ & Flamez et al. (2002) \\
\hline Abcc8 (Sur1) & G10 vs G3 & Up & $\begin{array}{l}\text { Cultured purified male } \\
\text { Wistar rat } \beta \text { cells ( } 24 \mathrm{~h} \text { ) }\end{array}$ & Flamez et al. (2002) \\
\hline$V d c c \alpha 1 D$ & Fed vs fasted & Up & $\begin{array}{l}\text { Fasted male Sprague-Dawley } \\
\text { rats }(72 \mathrm{~h})\end{array}$ & Iwashima et al. (1994) \\
\hline Serca2b (Atp2a2) & G10 vs G2-5 & Up & $\begin{array}{l}\text { Cultured male Wistar rat } \\
\text { islets }(18 \mathrm{~h})\end{array}$ & Bensellam et al. (2009) \\
\hline Serca3 (Atp2a3) & G10 vs G2-5 & Up & $\begin{array}{l}\text { Cultured male Wistar rat } \\
\text { islets }(18 \mathrm{~h})\end{array}$ & Bensellam et al. (2009) \\
\hline Gipr & G10 vs G5 & Up & $\begin{array}{l}\text { Cultured purified male } \\
\text { Wistar rat } \beta \text { cells }(72 \mathrm{~h})\end{array}$ & $\begin{array}{l}\text { Martens \& Pipeleers } \\
\text { (2009) }\end{array}$ \\
\hline Gpr40 (Ffar1) & G10 vs G5 & Up & $\begin{array}{l}\text { Cultured C57BL6J mouse } \\
\text { islets }(24 \mathrm{~h})\end{array}$ & (Supplementary Fig. 1) \\
\hline Slc30a1 (ZnT-1) & G10 vs G2-5 & Down & $\begin{array}{l}\text { Cultured male Wistar rat } \\
\text { islets }(18 \mathrm{~h})\end{array}$ & Bensellam et al. (2009) \\
\hline \multicolumn{5}{|c|}{ Proinsulin processing and insulin granule exocytosis } \\
\hline $\begin{array}{l}\text { Pcsk1, Pcsk2, Cpe, Scg3, Syt13, Sytl4, } \\
\text { Snap25, Syp, Scfd1, Ykt6 }\end{array}$ & G10 vs G2-5 & Up & $\begin{array}{l}\text { Cultured male Wistar rat } \\
\text { islets }(18 \mathrm{~h}) \text { and purified } \beta \\
\text { cells }(72 \mathrm{~h})\end{array}$ & $\begin{array}{l}\text { Bensellam et al. (2009), } \\
\text { Martens \& Pipeleers } \\
\text { (2009) }\end{array}$ \\
\hline
\end{tabular}

the differentiated $\beta$-cell phenotype also relies on gene repression. The latter involves particular mechanisms including epigenetic and miRNA regulation. Thus, histone and DNA methylation are implicated in the metabolic maturation of $\beta$-cells in the postnatal period by repressing the expression of Hk1, Mct1 and Ldha (Thorrez et al. 2011, Dhawan et al. 2015). Moreover, a growing body of data suggests that miRNAs are implicated not only in the repression of $\beta$-cell forbidden genes (Pullen et al. 2011, Martinez-Sanchez et al. 2015), but also in the modulation of insulin gene expression (El Ouaamari et al. 2008, Tang et al. 2009, Melkman-Zehavi et al. 2011, Zhao et al. 2012), the metabolic reconfiguration of neonatal $\beta$-cells (Jacovetti et al. 2015) and insulin granule exocytosis

\begin{tabular}{|lr} 
http://joe.endocrinology-journals.org & C 2018 Society for Endocrinology \\
https://doi.org/10.1530/JOE-17-0516 & Published by Bioscientifica Ltd. \\
Printed in Great Britain
\end{tabular}

(Poy et al. 2004, Lovis et al. 2008, Latreille et al. 2014). The switch from high-fat milk in newborns to carbohydraterich diet post-weaning has been suggested as an important driver of changes in miRNA expression that paralleled the maturation of the $\beta$-cell phenotype (Jacovetti et al. 2015). In agreement, glucose stimulation has been shown to regulate the expression of several miRNAs in $\beta$-cell lines and isolated islets (El Ouaamari et al. 2008, Esguerra et al. 2011). Recent reports have revealed another mechanism of gene repression whereby the transcription factors NK2 homeobox 2 (NKX2.2), paired box 6 (PAX6) and Regulatory Factor X, 6 (RFX6) play a dual role by activating the expression of various $\beta$-cell-enriched genes and also by directly binding to and repressing the expression of 
non- $\beta$-cell endocrine genes and other islet forbidden genes such as Ldha (Piccand et al. 2014, Gutierrez et al. 2017, Swisa et al. 2017). Of note, Nkx2.2 mRNA levels were upregulated in rat islets cultured in the presence of G10 instead of G2-5 (Bensellam et al. 2009).

However, while physiological glucose stimulation plays a key role in the maintenance of the $\beta$-cell differentiated phenotype, exposure to supraphysiological glucose levels, such as in the context of diabetes, leads to $\beta$-cell dedifferentiation. This may contribute to the progressive loss of functional $\beta$-cell mass and the aggravation of the disease over time. Our understanding of this phenomenon has markedly expanded in the last two decades with the identification of various mechanisms and effectors.

\section{The loss of $\beta$-cell differentiation in diabetes: causes and mechanisms}

\section{The loss of functional $\beta$-cell mass does not only result from apoptosis but also result from a loss of differentiation}

It is now well recognized that the $\beta$-cell mass is reduced by $25-60 \%$ in T2D patients in comparison to weightmatched normal subjects (Sakuraba et al. 2002, Butler et al. 2003, Yoon et al. 2003, Deng et al. 2004, Rahier et al. 2008). The observation that $\beta$-cell mass decline correlated with the duration of T2D (Rahier et al. 2008) supports a role of chronic hyperglycemia and glucotoxicity. Indeed, prolonged or intermittent exposure of rodent and human islets to elevated glucose concentrations in vitro has been shown to increase $\beta$-cell apoptosis (Ling et al. 1994, Efanova et al. 1998, Piro et al. 2002, Khaldi et al. 2004, DelGuerra et al. 2007, Hou et al. 2008b, Bensellam et al. 2009, Jonas et al. 2009). These results are strongly supported by the observation of increased $\beta$-cell apoptosis in different animal models of T2D (Koyama et al. 1998, Pick et al. 1998, Donath et al. 1999, Finegood et al. 2001, Huang et al. 2007, Song et al. 2008) and in human patients (Butler et al. 2003, Jurgens et al. 2011). However, the rate of $\beta$-cell apoptosis is relatively low and may not fully explain the loss of $\beta$-cell mass in T2D. Thus, alternative mechanisms are possible. The concept of the loss of differentiation, introduced in the late nineties (Jonas et al. 1999), has been recently proposed as an important contributor to the reduced $\beta$-cell mass in T2D (Talchai et al. 2012, Marselli et al. 2014, Spijker et al. 2015, Cinti et al. 2016). Similar to apoptosis, chronic hyperglycemia has been shown to be a major inducer of $\beta$-cell dedifferentiation.

\section{Role of hyperglycemia and glucotoxicity}

In T2D, the complex interaction of genetic and environmental factors leads ultimately to defective insulin secretion. The latter is a consequence of the failure of $\beta$-cells to cope with the important metabolic demand imposed on them by insulin resistance. The ensuing chronic hyperglycemia exerts further damage on the $\beta$-cell phenotype thereby leading to the progressive decline of functional $\beta$-cell mass and deterioration of the disease over time. This is the concept of glucotoxicity (Bensellam et al. 2012b). Glucotoxicity-related loss of $\beta$-cell identity is characterised by alterations in the expression of many genes, with much initial and recent attention focused on the reduced expression of $\beta$-cell-enriched genes, in particular insulin.

\section{Downregulation of insulin gene expression}

Earlier studies in $\beta$-cell lines and isolated rodent and human islets have shown that prolonged exposure to elevated glucose concentrations markedly reduced the mRNA levels of insulin (Robertson et al. 1992, Olson et al. 1995, 1998, Briaud et al. 1999, Marshak et al. 1999). In agreement, a similar reduction was observed in the islets of Zucker diabetic fatty (ZDF) rats (Harmon et al. 2001) and 90\% pancreatectomized (Px) rats (Jonas et al. 1999). Interestingly, in these animal models, insulin mRNA levels were restored by phlorizin treatment (an inhibitor of renal glucose reabsorption) and normalization of glycaemia (Jonas et al. 1999, Harmon et al. 2001). Reduced insulin mRNA levels have also been confirmed in $\beta$-cells of human T2D subjects (Marchetti et al. 2004, DelGuerra et al. 2005, Marselli et al. 2010, Guo et al. 2013). This reduction has been attributed to reduced expression and binding of the key transcription factors, pancreatic and duodenal homeobox 1 (PDX-1 also called IPF-1, STF1, IUF-1, IDX-1 or GSF) and V-maf musculoaponeurotic fibrosarcoma oncogene homolog A (MAFA also known as RIPE3b1), to the insulin gene promoter (Olson et al. 1995, Sharma et al. 1995, Poitout et al. 1996, Moran et al. 1997, Harmon et al. 1998, Marshak et al. 1999, Gleason et al. 2000, Pino et al. 2005, Matsuoka et al. 2010) (Fig. 3 and Supplementary Fig. 1, see section on supplementary data given at the end of this article). Reduced mRNA levels of $P d x 1$ and Mafa and nuclear expression of their proteins has also been reported in the islets of T2D patients (Guo et al. 2013). The reduction of the mRNA levels of $P d x 1$ in the islets of Px rats and Neurod1 in the islets of $d b / d b$ mice was prevented by phlorizin treatment, thereby demonstrating the role of glucotoxicity (Jonas et al. 1999, 


\begin{tabular}{l|l|l|l|l|}
\hline $\begin{array}{l}\text { Journal of } \\
\text { Endocrinology }\end{array}$ & M Bensellam et al. & $\begin{array}{l}\beta \text {-cell dedifferentiation in } \\
\text { diabetes }\end{array}$ & $\mathbf{2 3 6 : 2}$ & $\mathbf{R 1 1 7}$ \\
\hline
\end{tabular}

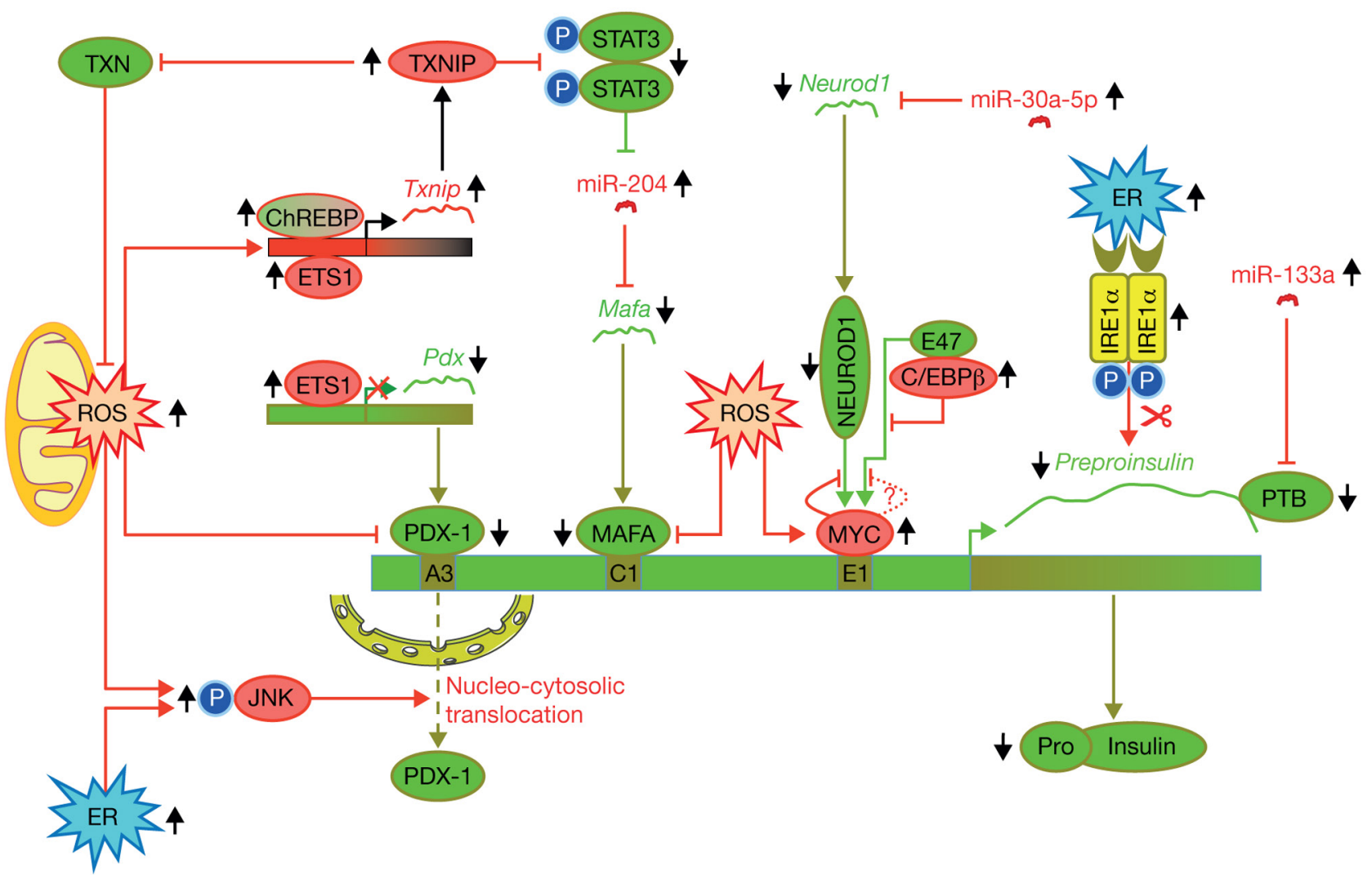

\section{Figure 3}

Schematic representation of the key effectors and mechanisms implicated in the loss of insulin gene expression in type 2 diabetes. Please see the text for details. Direction of the vertical black arrows close to proteins, mRNAs, miRNAs or stresses indicate the effect of glucotoxicity. C/EBP $\beta$, CCAAT/enhancerbinding protein $\beta$; ChREBP, carbohydrate response element binding protein; ER, endoplasmic reticulum; JNK, c-Jun N-terminal kinase; ROS, reactive oxygen species; ETS1, V-ets avian erythroblastosis virus E26 oncogene homolog 1; IRE1 $\alpha$, inositol requiring 1 $\alpha$; MAFA, V-maf musculoaponeurotic fibrosarcoma oncogene homolog A; MYC, myelocytomatosis viral oncogene homolog (avian); NEUROD1, neurogenic differentiation 1; PDX-1, pancreatic and duodenal homeobox 1; PTB, polypyrimidine tract binding protein; STAT3, signal transducer and activator of transcription 3; TXN, thioredoxin; TXNIP, thioredoxin-interacting protein.

Kjorholt et al. 2005). These results are further corroborated by a study showing that treatment of $d b / d b$ mice with the sodium glucose cotransporter 2 (SGLT2) inhibitor luseogliflozin upregulated islet mRNA levels of insulin, Pdx1 and Mafa (Okauchi et al. 2016).

The observation that the alteration of insulin gene expression was prevented by antioxidant treatment suggested an implication of oxidative stress (Tanaka et al. 1999, Robertson \& Harmon 2006). In support of this idea, hydrogen peroxide treatment of $\beta$-cell lines and isolated islets has been shown to alter the nuclear expression and DNA-binding activity of MAFA and PDX1 (Kaneto et al. 2002b, Harmon et al. 2005, Guo et al. 2013). Moreover, reduced nuclear expression of MAFA in the islets of diabetic $d b / d b$ mice was restored by transgenic expression of the antioxidant gene Gpx1 (Harmon et al. 2009, Guo et al. 2013). Similarly, altered nuclear expression of PDX1 and MAFA in the islets of diabetic ZDF rats was markedly prevented by treatment with the glutathione peroxidase (GPX) mimetic ebselen (Mahadevan et al. 2013). Oxidative stress-mediated alteration of PDX1 nuclear localization and DNA-binding activity has been proposed to involve the activation of c-Jun N-terminal kinase (JNK) (Kaneto et al. 2002b, Kawamori et al. 2003) (Fig. 3). Besides oxidative stress, it has been proposed that chronic ER stress could affect the specificity of the endoribonuclease activity of IRE1, thus leading to the cleavage of ER-associated RNAs including that of insulin (Hollien \& Weissman 2006, Pirot et al. 2007, Lipson et al. 2008, Han et al. 2009, Hollien et al. 2009) (Fig. 3). Moreover, other mechanisms have been identified implicating novel effectors, in particular miRNAs. Thus, it has been demonstrated that the high glucose-induced redox protein thioredoxin-interacting protein (TXNIP) (Shalev et al. 2002, Saxena et al. 2010), 
via a STAT3-dependent pathway, upregulated miR-204 thereby leading to reduced Mafa mRNA levels (Xu et al. 2013) (Fig. 3). In addition, upregulation of miR-30a-5p by high glucose levels in INS1 cells and rat islets has been shown to inhibit Neurod1 expression (Kim et al. 2013) (Fig. 3). Furthermore, in human islets exposed to high glucose, the induction of miR-133a targeted the polypyrimidine tract-binding protein and led to reduced insulin biosynthesis, although insulin mRNA levels were not significantly affected in this study (Fred et al. 2010) (Fig. 3). Another report has also shown that miR-124a is markedly upregulated in the islets of human T2D subjects and targeted Foxa2 and Neurod1 in MIN6 cells. Interestingly, overexpression of miR-124a blunted GSIS in MIN6 cells (Sebastiani et al. 2015). However, it is unclear whether miR-124a is regulated by glucotoxicity or another mechanism in T2D. On the other hand, the alteration of insulin gene expression under glucotoxic conditions also involves transcriptional repression by transcriptional repressor proteins. Thus, upregulation of CCAAT/enhancer-binding protein $\beta(\mathrm{C} / \mathrm{EBP} \beta)$ in $\beta$-cell lines and islets of ZDF and Px rats has been implicated in the downregulation of insulin gene expression ( $\mathrm{Lu}$ et al. 1997, Seufert et al. 1998). С/ЕВPß interacted with the basic helix-loop-helix transcription factor E47 thereby inhibiting its DNA binding to the insulin gene promoter and its transactivation ability (Fig. 3). High glucose also affected insulin gene transcription by upregulating the expression of myelocytomatosis viral oncogene homolog (avian) (MYC). MYC has been shown to inhibit neurogenic differentiation 1 (NEUROD1, also known as BETA2)-mediated transcriptional activation of the insulin gene promoter in $\beta$-cell lines and isolated rat islets (Kaneto et al. 2002a) (Fig. 3). Of note, $M y c$ is also an oxidative stress-responsive gene (Elouil et al. 2005, Jonas et al. 2009) that has been implicated in $\beta$-cell dedifferentiation (Jonas et al. 2001, Laybutt et al. 2002c, Pascal et al. 2008, Robson et al. 2011). On the other hand, it has been proposed that Myc expression is negatively regulated by PDX1 (Chen et al. 2007). More recently, V-ets avian erythroblastosis virus E26 oncogene homolog 1 (ETS1) has been shown to repress the expression of $P d x 1$ under glucotoxicity by directly binding to its promoter and inhibiting its transcription in rodent $\beta$-cells (Chen et al. 2016) (Fig. 3). This study also suggested that ETS1 could interact with the transcription factor forkhead box O1 (FOXO1) and increase its binding to the $P d x 1$ promoter (Chen et al. 2016). FOXO1 has previously been proposed to repress FOXA2-dependent $P d x 1$ transcription and to be involved in the nucleocytoplasmic translocation of PDX1 under oxidative stress (Kitamura et al. 2002, Kawamori et al. 2006). However, findings in the last decade revealed that the loss of FOXO1 under severe hyperglycemia is implicated in $\beta$-cell dedifferentiation thereby indicating a complex role of this transcription factor in $\beta$-cell pathophysiology (discussed in the next section).

\section{Downregulation of $\boldsymbol{\beta}$-cell-enriched genes}

Besides the insulin gene and key upstream transcription factors, glucotoxicity alters the expression of additional genes that maintain the differentiated $\beta$-cell phenotype including other transcription factors such as Nkx6.1, $H n f 1 \alpha$ (also known as Tcf1) and $H n f 4 \alpha$, glucose sensing and metabolism genes such as Glut2, Gck and Gpd2 (Supplementary Fig. 1), stimulus-secretion coupling genes such as Kcnj11 and $A b c c 8$, amplification of insulin secretion genes such as Glp1r, Chrm3 and Gpr40 (Supplementary Fig. 1) and insulin granule exocytosis genes such as N-ethylmaleimide-sensitive factor attachment protein receptor (SNARE) complex proteins. A comprehensive and up to date list of the most important genes and the models in which they are affected are presented in Table 2. Many of these alterations, but not all, have also been confirmed in islets of human T2D subjects (Table 2). The normalization of these alterations in diabetic animals using phlorizin treatment, sulfonylureas or insulin therapy, but not bezafibrate treatment, strongly supports the implication of glucotoxicity rather than lipotoxicity (Jonas et al. 1999, Harmon et al. 2001, Gaisano et al. 2002, Kjorholt et al. 2005, Xu et al. 2007, Brereton et al. 2014, Wang et al. 2014). Several pathways downstream of glucotoxicity (Bensellam et al. 2012b) have been implicated in the loss of $\beta$-cellenriched genes including oxidative stress (Tanaka et al. 1999, Kaneto et al. 2002b, Harmon et al. 2005, Robertson \& Harmon 2006, Guo et al. 2013), ER stress (Hollien \& Weissman 2006, Pirot et al. 2007, Lipson et al. 2008, Han et al. 2009, Szabat et al. 2011, Lombardi et al. 2012), the hexosamine pathway (Kaneto et al. 2001, Yoshikawa et al. 2002), inflammation (Nordmann et al. 2017) and hypoxia (Puri et al. 2013, Sato et al. 2014, 2017).

Downregulation of the $\beta$-cell-enriched genes is linked with altered expression of key transcription factors. Indeed, above and beyond the regulation of insulin gene expression, the $\beta$-cell key transcription factors PDX1, MAFA and NEUROD1, in addition to hepatocyte nuclear factors (HNF1 $\alpha, \mathrm{HNF} 4 \alpha$ and HNF3 $\beta /$ FOXA2) and PAX6, are implicated in a complex network of inter-regulation (Ben-Shushan et al. 2001, Samaras et al. 2002, 2003, Shih et al. 2002, Pedersen et al. 2005) and regulation of other $\beta$-cell-enriched genes including key metabolic genes such 


\begin{tabular}{l|l|l|c|}
$\begin{array}{l}\text { Journal of } \\
\text { Endocrinology }\end{array}$ & $\begin{array}{l}\beta \text {-cell dedifferentiation in } \\
\text { diabetes }\end{array}$ & $\mathbf{2 3 6 : 2}$ & $\mathbf{R} 119$ \\
\hline
\end{tabular}

Table 2 Downregulation of $\beta$-cell-enriched genes under glucotoxicity.

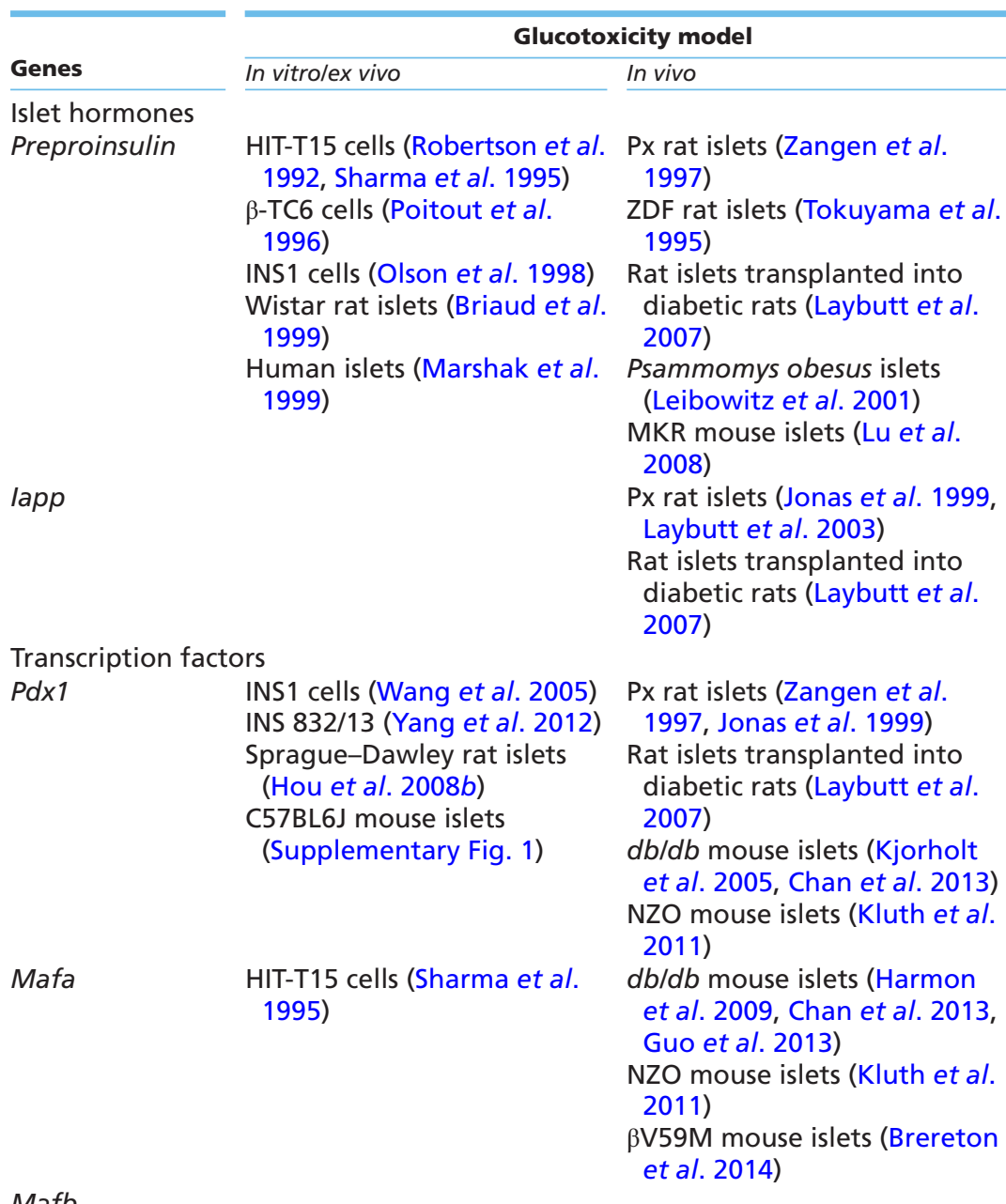

Mafb

Neurod1 (Beta2)

Px rat islets (Jonas et al. 1999, Laybutt et al. 2003)

Rat islets transplanted into diabetic rats (Laybutt et al. 2007)

$d b / d b$ mouse islets (Kjorholt

et al. 2005, Chan et al. 2013)

$N k \times 6.1$

Px rat islets (Jonas et al. 1999, Laybutt et al. 2003)

Rat islets transplanted into diabetic rats (Laybutt et al. 2007)

$d b / d b$ mouse islets (Kjorholt et al. 2005, Chan et al. 2013, Guo et al. 2013)

NZO mouse islets (Kluth et al. 2011)

$\beta \mathrm{V} 59 \mathrm{M}$ mouse islets (Brereton et al. 2014)

$H n f 1 \alpha(T c f 1)$

Px rat islets (Jonas et al. 1999, Laybutt et al. 2003)

$H n f 4 \alpha$

Px rat islets (Jonas et al. 1999, Laybutt et al. 2003)

Confirmation in human T2D

Glucotoxic effect

Yes: (Marchetti et al. 2004, DelGuerra et al. 2005, Masini et al. 2012, Guo et al. 2013)

mRNA, protein and volume density of insulin granules

Yes: (Marselli et al. 2010, mRNA Bugliani et al. 2013)

Controversial

DNA

Yes: (Ostenson et al. 2006, Yang et al. 2012, Guo et al. 2013)

Upregulated: (DelGuerra et al. 2005)

methylation, mRNA, protein, and subcellular localization

Yes: (Guo et al. 2013, Cinti et al. 2016)

mRNA, protein and subcellular localization

Yes: (Bugliani et al. 2013, Guo et al. 2013)

Yes: (Guo et al. 2013, Cinti et al. 2016)

mRNA, protein and subcellular localization
mRNA, protein and subcellular localization mRNA
Yes: (Marselli et al. 2010)

Yes: (Gunton et al. 2005) 
Table 2 Continued.

\begin{tabular}{|c|c|c|c|c|}
\hline \multirow[b]{2}{*}{ Genes } & \multicolumn{2}{|c|}{ Glucotoxicity model } & \multirow[b]{2}{*}{ Confirmation in human T2D } & \multirow[b]{2}{*}{ Glucotoxic effect } \\
\hline & In vitrolex vivo & In vivo & & \\
\hline Hnf3 $\beta$ (Foxa2) & & Px rat islets (Jonas et al. 1999) & & mRNA \\
\hline Pax6 & & $\begin{array}{l}\text { Rat islets transplanted into } \\
\text { diabetic rats (Laybutt et al. } \\
\text { 2007) } \\
\text { db/db mouse islets (Kjorholt } \\
\text { et al. 2005, Swisa et al. 2017) }\end{array}$ & & mRNA \\
\hline Foxo1 & & $\begin{array}{l}\text { GIRKO mouse islets (Talchai } \\
\text { et al. 2012) } \\
\text { db/db mouse islets (Kim-Muller } \\
\text { et al. 2014) }\end{array}$ & $\begin{array}{l}\text { Controversial } \\
\text { Yes: (Marselli et al. 2010, } \\
\text { Cinti et al. 2016) } \\
\text { Upregulated: (DelGuerra } \\
\text { et al. 2005) }\end{array}$ & $\begin{array}{l}\text { mRNA and } \\
\text { protein }\end{array}$ \\
\hline$T c f 7 / 2(T c f 4)$ & & $\begin{array}{l}\text { Vancouver Diabetic Fatty (VDF) } \\
\text { Zucker rat islets (Shu et al. } \\
\text { 2009) } \\
\text { db/db mouse islets (Shu et al. } \\
2009 \text { ) }\end{array}$ & Yes: (Shu et al. 2009) & Protein \\
\hline Glucose transno & $\begin{array}{l}\text { INS 832/13 (Roduit et al. } \\
\text { 2000) } \\
\text { Wistar rat islets (Roduit } \\
\text { et al. 2000) }\end{array}$ & $\begin{array}{l}\text { Px rat islets (Laybutt et al. } \\
2002 b \text { ) } \\
\text { ZDF rat islets (Wang et al. } \\
\text { 1998) }\end{array}$ & & $\begin{array}{l}\text { mRNA and } \\
\text { protein }\end{array}$ \\
\hline $\begin{array}{l}\text { Glucose transpo } \\
\text { Glut1 }\end{array}$ & and metabolism & & $\begin{array}{l}\text { Yes: (DelGuerra et al. 2005, } \\
\text { Guo et al. 2013) }\end{array}$ & mRNA \\
\hline Glut2 & $\begin{array}{l}\text { INS1 cells (Wang et al. 2005) } \\
\text { C57BL6J mouse islets } \\
\text { (Supplementary Fig. 1) }\end{array}$ & $\begin{array}{l}\text { Px rat islets (Jonas et al. 1999, } \\
\text { Laybutt et al. 2003) } \\
\text { Rat islets transplanted into } \\
\text { diabetic rats (Laybutt et al. } \\
\text { 2007) } \\
\text { db/db mouse islets (Thorens } \\
\text { et al. 1992, Kjorholt et al. } \\
\text { 2005, Chan et al. 2013, Guo } \\
\text { et al. 2013) } \\
\text { ßV59M mouse islets (Brereton } \\
\text { et al. 2014) }\end{array}$ & $\begin{array}{l}\text { Yes: (DelGuerra et al. 2005, } \\
\text { Ostenson et al. 2006, } \\
\text { Marselli et al. 2010, } \\
\text { Taneera et al. 2012, Guo } \\
\text { et al. 2013) }\end{array}$ & $\begin{array}{l}\text { mRNA and } \\
\text { protein }\end{array}$ \\
\hline Gck & INS1 cells (Wang et al. 2005) & $\begin{array}{l}\text { Px rat islets (Jonas et al. 1999, } \\
\text { Laybutt et al. 2003) } \\
\text { ZDF rat islets (Tokuyama et al. } \\
\text { 1995) } \\
\text { Rat islets transplanted into } \\
\text { diabetic rats (Laybutt et al. } \\
\text { 2007) } \\
\text { db/db mouse islets (Kjorholt } \\
\text { et al. 2005, Chan et al. 2013) }\end{array}$ & Yes: (DelGuerra et al. 2005) & mRNA \\
\hline$P c$ & & $\begin{array}{l}\text { Px rat islets (Jonas et al. 1999, } \\
\text { Laybutt et al. 2003) } \\
\text { ZDF rat islets (MacDonald et al. } \\
\text { 1996) } \\
\text { db/db mouse islets (Kjorholt } \\
\text { et al. 2005, Chan et al. 2013) } \\
\text { MKR mouse islets (Lu et al. } \\
\text { 2008) }\end{array}$ & Yes: (MacDonald et al. 2009) & $\begin{array}{l}\text { mRNA, protein } \\
\text { and enzyme } \\
\text { activity }\end{array}$ \\
\hline Gpd2 (mGpdh) & $\begin{array}{l}\text { C57BL6J mouse islets } \\
\text { (Supplementary Fig. 1) }\end{array}$ & $\begin{array}{l}\text { Px rat islets (Jonas et al. 1999, } \\
\text { Laybutt et al. 2003) } \\
\text { ZDF rat islets (Tokuyama et al. } \\
\text { 1995, MacDonald et al. 1996) } \\
\text { db/db mouse islets (Kjorholt } \\
\text { et al. 2005, Chan et al. 2013) } \\
\text { MKR mouse islets (Lu et al. 2008) }\end{array}$ & $\begin{array}{l}\text { Yes: (MacDonald et al. 2009, } \\
\text { Marselli et al. 2010) }\end{array}$ & $\begin{array}{l}\text { mRNA and } \\
\text { enzyme activity }\end{array}$ \\
\hline
\end{tabular}


Table 2 Continued.

\begin{tabular}{|c|c|c|}
\hline \multirow[b]{2}{*}{ Genes } & \multicolumn{2}{|c|}{ Glucotoxicity model } \\
\hline & In vitro/ex vivo & In vivo \\
\hline Acly & & $\begin{array}{l}\text { GK rat islets (Homo-Delarche } \\
\text { et al. 2006, Hasan et al. 2010) }\end{array}$ \\
\hline \multicolumn{3}{|c|}{ Receptors, ion channels and pumps } \\
\hline Glp1r & $\begin{array}{l}\text { Sprague-Dawley rat islets } \\
\text { (Xu et al. 2007) }\end{array}$ & $\begin{array}{l}\text { Px rat islets (Xu et al. 2007) } \\
\text { GK rat islets (Homo-Delarche } \\
\text { et al. 2006) } \\
\text { Glucose-infused rat islets (Xu } \\
\text { et al. 2007) } \\
\text { db/db mouse islets (Chan et al. } \\
\text { 2013) }\end{array}$ \\
\hline Gipr & & $\begin{array}{l}\text { Px rat islets (Xu et al. 2007) } \\
d b / d b \text { mouse islets (Chan et al. } \\
\text { 2013) }\end{array}$ \\
\hline Gpr40 & $\begin{array}{l}\text { C57BL6J mouse islets } \\
\text { (Supplementary Fig. 1) }\end{array}$ & $\begin{array}{l}d b / d b \text { mouse islets (Chan et al. } \\
\text { 2013) }\end{array}$ \\
\hline Chrm3 & $\begin{array}{l}\text { ICR mouse islets (Hauge- } \\
\text { Evans et al. 2014) }\end{array}$ & $\begin{array}{l}\text { ob/ob mouse islets (Hauge- } \\
\text { Evans et al. 2014) }\end{array}$ \\
\hline Kcnj11 (Kir6.2) & & $\begin{array}{l}\text { Px rat islets (Jonas et al. 1999, } \\
\text { Laybutt et al. 2003) } \\
\text { ZDF rat islets (Tokuyama et al. } \\
\text { 1995) } \\
\text { db/db mouse islets (Kjorholt } \\
\text { et al. 2005, Chan et al. 2013) }\end{array}$ \\
\hline
\end{tabular}

Abcc8 (Sur1)

Px rat islets (Jonas et al. 1999)

$V d c c \alpha 1 D$

ZDF rat islets (Tokuyama et al. 1995)

$\operatorname{Vdcc} \beta$

Px rat islets (Laybutt et al. 2003)

Serca2b

(Atp2a2b)

Px rat islets (Jonas et al. 1999) $d b / d b$ mouse islets (Kjorholt et al. 2005)

Serca3 (Atp2a3)

Px rat islets (Jonas et al. 1999) $d b / d b$ mouse islets (Kjorholt et al. 2005)

Hormone processing and insulin granule exocytosis

Pcsk1 (Pc1)

Pcsk2 (Pc2)

Cpe

Stx1a

INS1E cells (Dubois et al. 2007)

Sprague-Dawley rat islets (Torrejon-Escribano et al. 2011)

Stxbp1

(Munc18-1)

SNAP-25
MKR mouse islets (Lu et al. 2008)

MKR mouse islets (Lu et al. 2008)

MKR mouse islets (Lu et al. 2008)

GK rat islets (Nagamatsu et al. Yes: (Ostenson et al. 2006) 1999, Gaisano et al. 2002, Zhang et al. 2002b) $d b / d b$ mouse islets (Do et al. 2014)

GK rat islets (Zhang et al. 2002b)

GK rat islets (Nagamatsu et al. Yes: (Ostenson et al. 2006) 1999, Gaisano et al. 2002, Zhang et al. 2002b)

Yes: (Masini et al. 2012)

\section{Confirmation in human T2D}

Yes: (MacDonald et al. 2009, Marselli et al. 2010 Bugliani et al. 2013)

Yes: (Shu et al. 2009, Taneera et al. 2012, Guo et al. 2013)

Yes: (Shu et al. 2009)

mRNA and protein

mRNA

mRNA and protein

mRNA

Taneera et al. 2012)

Yes: (Ostenson et al. 2006, Marselli et al. 2010)

Yes: (Marselli et al. 2010) mRNA

Yes: (Bugliani et al. 2013)

mRNA

mRNA

mRNA

mRNA and protein

Protein

mRNA and protein mRNA and protein

mRNA and protein mRNA and protein

(Continued) 
Table 2 Continued.

\begin{tabular}{|c|c|c|c|c|}
\hline \multirow[b]{2}{*}{ Genes } & \multicolumn{2}{|c|}{ Glucotoxicity model } & \multirow[b]{2}{*}{ Confirmation in human T2D } & \multirow[b]{2}{*}{ Glucotoxic effect } \\
\hline & In vitrolex vivo & In vivo & & \\
\hline Vamp2 & $\begin{array}{l}\text { INS1E cells (Dubois et al. } \\
\text { 2007) } \\
\text { Wistar (Gaisano et al. 2002) } \\
\text { and Sprague-Dawley rat } \\
\text { islets (Torrejon-Escribano } \\
\text { et al. 2011) } \\
\text { Human islets (Dubois et al. } \\
\text { 2007) }\end{array}$ & $\begin{array}{l}\text { Px rat islets (Torrejon-Escribano } \\
\text { et al. 2011) } \\
\text { GK rat islets (Gaisano et al. } \\
\text { 2002, Zhang et al. 2002b) } \\
\text { Rat islets transplanted into } \\
\text { diabetic rats (Torrejon- } \\
\text { Escribano et al. 2011) } \\
\text { MKR mouse islets (Lu et al. 2008) }\end{array}$ & Yes: (Ostenson et al. 2006) & $\begin{array}{l}\text { mRNA and } \\
\text { protein }\end{array}$ \\
\hline Vamp3 & $\begin{array}{l}\text { Sprague-Dawley rat islets } \\
\text { (Torrejon-Escribano et al. } \\
\text { 2011) }\end{array}$ & $\begin{array}{l}\text { Px rat islets (Torrejon-Escribano } \\
\text { et al. 2011) } \\
\text { Rat islets transplanted into } \\
\text { diabetic rats (Torrejon- } \\
\text { Escribano et al. 2011) }\end{array}$ & & Protein \\
\hline Syp & & & Yes: (Ostenson et al. 2006) & $\begin{array}{l}\text { mRNA and } \\
\text { protein }\end{array}$ \\
\hline Syt/4 & & $\begin{array}{l}\text { MKR mouse islets (Lu et al. } \\
\text { 2008) }\end{array}$ & & $\begin{array}{l}\text { mRNA and } \\
\text { protein }\end{array}$ \\
\hline
\end{tabular}

as Glut2, Gck and $P c$, ion channel genes such as $A b c c 8$ and receptor genes such as Glp1r (Waeber et al. 1996, Cha et al. 2000, Shih et al. 2001, Sund et al. 2001, Kim et al. 2002, Moates et al. 2003, Zhang et al. 2005, Wang et al. 2007). Interestingly, PDX1, NKX6.1 and PAX6 have also been shown to play a key role in preserving $\beta$-cell identity by repressing the expression of other islet cell type genes (Schaffer et al. 2013, Taylor et al. 2013, Gao et al. 2014, Mitchell et al. 2017, Swisa et al. 2017). Besides these canonical transcription factors, recent evidence has suggested that reduced expression of sex-determining region Y-box 5 (SOX5) may also contribute to the downregulation of $\beta$-cell-enriched genes in T2D (Axelsson et al. 2017). Adequate regulation of $\beta$-cell-enriched gene expression by these transcription factors depends on correct binding to specific promoters, but also on promoter-enhancer looping of chromatin and formation of multimeric transcriptional complexes. This has been shown to involve LIM domain-binding protein 1 (LDB1). LDB1, together with its binding partner islet 1 (ISL1), was enriched at DNA regions occupied by PDX1, NKX2.2, NKX6.1 and FOXA2 and LDB deletion in adult murine $\beta$-cells markedly affected the expression of $\beta$-cell-enriched genes including Mafa, Pdx1, Nkx6.1, Glut2, Kcnj11, Abcc8 and Glp1r. Interestingly, reduced LDB1 enrichment in a putative active enhancer nearby GLUT2 gene has been observed in islets from T2D donors (Ediger et al. 2017). But whether dysregulation of LDB1 is involved in downregulation of other $\beta$-cell-enriched genes in human $\mathrm{T} 2 \mathrm{D}$ requires further exploration.

Gene inhibition/overexpression strategies in vitro and in vivo have allowed a better understanding of the implication of these genes in the alteration of $\beta$-cell identity and function. The numerous forms of the maturity-onset diabetes of the young (MODY) best illustrate this in humans. These monogenic disorders result from mutations in transcription factor genes such

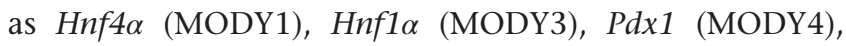
Hnf1 $\beta$ (MODY5) and Neurod1 (MODY6), and mutations in ion channel and metabolic genes such as Gck (MODY2), Abcc8 (MODY12) and Kcnj11 (MODY13) (Hattersley \& Patel 2017). However, despite important advances in this field, there are still significant gaps of knowledge with regards to the precise targets of these transcription factors, their complex interaction network and the identification of novel transcription factors implicated in the loss of $\beta$-cell identity.

In recent years, FOXO1 has received much attention as a potential transcription factor linking metabolic stress with $\beta$-cell dedifferentiation in T2D. FOXO1 is a multifunctional transcription factor that has been shown to play complex adaptive/deleterious roles in $\beta$-cells under stress depending on the context. Thus, evidence showed that FOXO1 translocates to the nucleus under oxidative stress and promotes the expression of Neurod1 and Mafa (Kitamura et al. 2005). In transgenic mouse models, FOXO1 has been shown to play a role in $\beta$-cell compensation during insulin resistance via increasing $\beta$-cell proliferation, mass, function and antioxidant gene expression (Okamoto et al. 2006, Zhang et al. 2016). Interestingly, Foxo1 somatic deletion in $\beta$-cells resulted in $\beta$-cell dedifferentiation in ageing male mice and multiparous female mice in parallel with the upregulation of progenitor and pluripotency markers (Talchai et al. 2012). Furthermore, loss of FOXO1 
has been observed in the islets of severely hyperglycemic $d b / d b$ mice and insulin-resistant GIRKO mice (Talchai et al. 2012, Kim-Muller et al. 2014). This observation was confirmed by the same group in human T2D islets and was associated with altered expression and nuclear localization of MAFA and NKX6.1 (Cinti et al. 2016). In contrast, FOXO1 nuclear translocation in response to glucose starvation or palmitate treatment has been implicated in $\beta$-cell apoptosis, at least in part, via the stimulation of Ddit3 gene expression (Martinez et al. 2006, 2008). FOXO1 subcellular localization and activity are modulated by posttranslational modifications including phosphorylation, ubiquitination, OGlcNacylation and acetylation (Kitamura 2013). In the NZO mouse model, a dietary carbohydrate challenge and the ensuing hyperglycemia were associated with rapid and marked dephosphorylation of FOXO1 (activation) followed by reduced GLUT2, PDX1, MAFA and NKX6.1 protein levels and increased apoptosis (Kluth et al. 2011), in agreement with the previously reported role of FOXO1 in the inhibition of $P d x 1$ transcription (Kitamura et al. 2002). However, in this model, it is unclear whether nuclear expression of active FOXO1 is upregulated and whether it declines thereafter or not (Kluth et al. 2011). Another study has shown increased nuclear expression of FOXO1 in $\beta$-cells of diabetic $d b / d b$ mice in association with downregulation of PDX1, MAFA and NKX6.1. Interestingly, caloric restriction for three months markedly reversed these alterations and normalized glycaemia and $\beta$-cell function (Sheng et al. 2016). Furthermore, increased mRNA levels of Foxo1 have been reported in the islets of T2D subjects (DelGuerra et al. 2005). All in all, although undeniable evidence supports an important adaptive role of FOXO1 in the preservation of $\beta$-cell identity, especially under hyperglycemia and subsequent oxidative stress, additional work is required to further elucidate the mechanisms and timing of activation/inhibition of FOXO1 in diabetes and identify its precise targets and interacting network. The use of models of inducible expression/deletion in adult animals could be useful.

Besides altered expression and subcellular localization of transcription factors, downregulation of $\beta$-cell-enriched genes also involves gene repression by epigenetic mechanisms and miRNAs. Thus, in the islets of human T2D patients, increased DNA methylation in the promoter and enhancer regions of $P d x 1$ has been proposed to be involved in its downregulation under hyperglycemia (Yang et al. 2012). Similarly, increased DNA methylation in the Glp1r promoter has been observed in the islets of human T2D subjects (Hall et al. 2013). We have highlighted in the previous section the implication of several miRNAs in the inhibition of insulin gene expression and upstream transcription factors (Fred et al. 2010, Kim et al. 2013, Xu et al. 2013, Sebastiani et al. 2015). In addition, various miRNAs upregulated in the islets of GK rats have been shown to target transport and secretory pathway genes (Esguerra et al. 2011). Moreover, it has recently been shown that upregulation of miR-130a-3p, miR-130b-3p and miR-152-3p in the islets of GK rats was associated with reduced protein expression of GCK and pyruvate dehydrogenase E1- $\alpha$ and reduced intracellular ATP levels. Upregulation of these miRNAs has also been confirmed in the islets of hyperglycemic human donors (Ofori et al. 2017). Furthermore, upregulation of miR187 in the islets of human T2D subjects was associated with altered GSIS and has been proposed to target Hipk3 (Locke et al. 2014), a gene encoding for a serine-threonine kinase implicated in the regulation of $\beta$-cell function and survival (Shojima et al. 2012). However, transfection of INS1 cells with miR187 mimetic had only a minor effect on Hipk3 mRNA levels and promoter activity, thereby suggesting the implication of other effectors (Locke et al. 2014). Thus, growing evidence supports an important role of miRNAs in the alteration of $\beta$-cell identity. Future studies are needed in this emerging field of research to identify which miRNAs are directly implicated in the loss of $\beta$-cell identity in T2D, map their precise targets and determine the upstream mechanisms of induction. A special attention in the in vitro studies must be paid to the duration of exposure to elevated glucose levels when evaluating the effects of glucotoxicity. Indeed, acute and sub-acute/chronic exposure may have different/opposite effects on the expression of some miRNAs (El Ouaamari et al. 2008, Esguerra et al. 2011, Sun et al. 2011). Altogether, these findings show the multiple levels at which glucotoxicity affects the $\beta$-cell phenotype as well as the various potential mechanisms of $\beta$-cell dedifferentiation in T2D. More large-scale studies, especially using human islets, human cell lines and/or human $\beta$-cells derived from induced pluripotent stem cells, are needed to validate and extend the findings in rodents and to understand the pathophysiological role of $\beta$-cell dedifferentiation in T2D.

In addition to the loss of insulin, transcription factor, metabolism and secretory pathway genes, a growing body of data indicates that the loss of the adaptive UPR is a key event that accompanies $\beta$-cell decompensation and progression towards diabetes. 
Failure of the adaptive UPR and progression towards diabetes

$\beta$-cells are vulnerable to ER stress due to their elevated rate of insulin biosynthesis in response to glucose stimulation. Therefore, an operational and fine-tuned UPR is fundamental for the preservation of $\beta$-cell function and survival under physiological conditions, and even more under conditions of high insulin demand, such as obesity and pregnancy. Indeed, genetic disruption of several UPR components, including Perk, eIF2 $\alpha$, Ire1, Xbp1 and Dnajc3 leads to $\beta$-cell demise and the development of insulin-dependent diabetes in man and rodents (Delepine et al. 2000, Harding et al. 2001, Zhang et al. 2002a, Ladiges et al. 2005, Back et al. 2009, Iwawaki et al. 2010, Julier \& Nicolino 2010, Lee et al. 2011, Synofzik et al. 2014, Xu et al. 2014, Han et al. 2015, Hassler et al. 2015). The UPR is thus an important trait of differentiated $\beta$-cells. Until recently, the accepted concept was that excessive stimulation of the UPR under chronic/unresolved ER stress plays an important role in $\beta$-cell decompensation and failure. This view was supported by several studies showing increased activation of ER stress sensors and downstream effectors and target genes in different in vitro and in vivo models in addition to human T2D (reviewed in Bensellam et al. $2012 b$ ). Furthermore, ablation of the ISR gene Ddit 3 in different animal models of diabetes has been shown to be protective (Oyadomari et al. 2002, Song et al. 2008), while overexpression of Trib3 altered glucose tolerance and GSIS and increased $\beta$-cell apoptosis (Qian et al. 2008, Liew et al. 2010, Fang et al. 2014). Moreover, adenovirus-mediated overexpression of Atf6 in INS1 cells was associated with altered GSIS and reduced expression of insulin, $P d x 1$ and Mafa (Seo et al. 2008). Likewise, overexpression of Xbp1 in primary rat $\beta$-cells was correlated with impaired function, increased apoptosis and reduced expression of insulin, Pdx1, Mafa and Glut2 (Allagnat et al. 2010). As described earlier, chronic IRE1 activation has also been shown to alter $\beta$-cell differentiation via the degradation of ER-localized insulin mRNA (Pirot et al. 2007, Lipson et al. 2008, Han et al. 2009).

However, emerging evidence has challenged this concept by showing in different models of obesity and insulin resistance that the loss of $\beta$-cell differentiation and progression towards diabetes is accompanied by failure of the adaptive UPR. This led to the hypothesis that $\beta$-cell dysfunction in T2D may result from a failure of the UPR to adequately adapt rather than from a maladaptive UPR (Herbert \& Laybutt 2016). By comparing timedependent gene expression changes in islets of diabetesprone ( $d b / d b$ mice on C57BL/KsJ genetic background) and diabetes-resistant (ob/ob mice on C57BL/6J genetic background) mouse models of obesity, we observed in $o b / o b$ mice a progressive upregulation of adaptive UPR genes, including Hspa5, Fkbp11 and Dnajc3, in parallel with the maintenance of increased spliced/total Xbp1 $(X b p 1 s / t)$ mRNA ratio. In contrast, adaptive UPR genes were upregulated in prediabetic $d b / d b$ mouse islets (6 weeks of age) but declined in diabetic mice (16 weeks of age) in parallel with a similar decline in Xbp1s/t mRNA ratio. Moreover, despite partial downregulation of some $\beta$-cell key transcription factor genes and other $\beta$-cell-enriched genes in prediabetic $d b / d b$ mice and agematched $o b / o b$ mice, the $\beta$-cell phenotype recovered in 16 -week-old $o b / o b$ mice. On the contrary, there was a further loss of these genes in 16-week-old diabetic $d b / d b$ mice. Interestingly, downregulation of $\beta$-cell-enriched genes in $d b / d b$ mouse islets was partially restored with the chemical chaperone 4-phenylbutyrate suggesting that the inactivation of the adaptive UPR plays a role in $\beta$-cell dedifferentiation (Chan et al. 2013). Downregulation of adaptive UPR gene expression is unlikely to result from reduced proinsulin biosynthesis since the latter has been shown to be increased in diabetic $d b / d b$ mice (Alarcon et al. 2016). These results were corroborated by similar observations in the islets of female ZDF (fZDF) rats. Thus, adaptive UPR genes were upregulated in the islets of obese, prediabetic fZDF rats fed a chow diet (model of $\beta$-cell compensation) in comparison to agematched lean controls. However, UPR gene expression was downregulated in diabetic fZDF rats fed a high-fat diet (model of $\beta$-cell decompensation) in comparison to age-matched obese, prediabetic fZDF rats fed a chow diet, in parallel with altered $\beta$-cell differentiation (Omikorede et al. 2013). Noteworthy, in vitro, proteomic analysis of glucose-responsive (low passage; more differentiated) vs glucose non-responsive (high passage; less differentiated) MIN6 cells also revealed downregulation of HSPA5, HSP90B1, PDI and ERP29 (Dowling et al. 2006). In humans, a previous microarray study has revealed a significant downregulation of $\mathrm{Hsp} 90 \mathrm{bl}$ in the islet of T2D donors (Gunton et al. 2005). A more recent study has confirmed and extended this finding by showing that numerous UPR, ER-Golgi (retrograde)transport, ER quality control, ERAD and (retro)translocon-related genes were significantly downregulated in islets of T2D donors vs BMI-matched non-diabetic subjects, including Perk, Hsp90b1, Hspa8, Hspa13, Ero1ß, Pdia6, Ppib, Erp44, Dnaja2, Dnajb9, Dnajc6, Dnajc9, Dnajc10, Dnajc12, Serp1, Man1a1, Cnx, Herpud1, Ssr1, Ssr3, Sec11a, Sec13, Sec23a, Sec23b, Sec23ip, Sec24a, Sec24b, Sec24d, Sec62, Sec63, 
Copb1, Copb2 and Copz1, in addition to downregulation of the ubiquitin-proteasome system genes and reduced proteasome activity (Bugliani et al. 2013). A following report examining protein expression of XBP1s, ATF6 and phosphorylated-eIF2 $\alpha$ in pancreatic sections from nonBMI-matched normal, prediabetic and diabetic women with different durations of diabetes has shown an overall decreased staining in the islets of diabetic vs control and prediabetic women for the three markers (Engin et al. 2014). Collectively, these observations support the notion that adaptive UPR inactivation occurs during the progression towards diabetes in rodents and humans and may play an important role in $\beta$-cell dedifferentiation. But what could be the mechanism(s) behind this inactivation?

Hyperglycemia and the ensuing glucotoxicity are primary candidates. Indeed, downregulation of adaptive UPR and ISR gene expression has been observed in mouse islets transplanted into diabetic mice with a non-sufficient islet number, in comparison to those transplanted into non-diabetic control mice. These alterations were paralleled by similar changes in the expression of $\beta$-cell key transcription factors and other $\beta$-cell-enriched genes, thereby further supporting a link between $\beta$-cell dedifferentiation and failure of the UPR. Interestingly, these alterations were prevented in mouse islets transplanted into diabetic mice with a sufficient number to restore normoglycaemia, thereby suggesting that hyperglycaemia contributes to the downregulation of the UPR (Walters et al. 2013). Glucotoxicity exerts its deleterious effects via myriad mechanisms, including hypoxia (Sato et al. 2011, 2014, Bensellam et al. 2012a,b). We have recently provided evidence that hypoxia could be an important cellular mechanism for the inactivation of the adaptive UPR in T2D. Thus, we have shown that

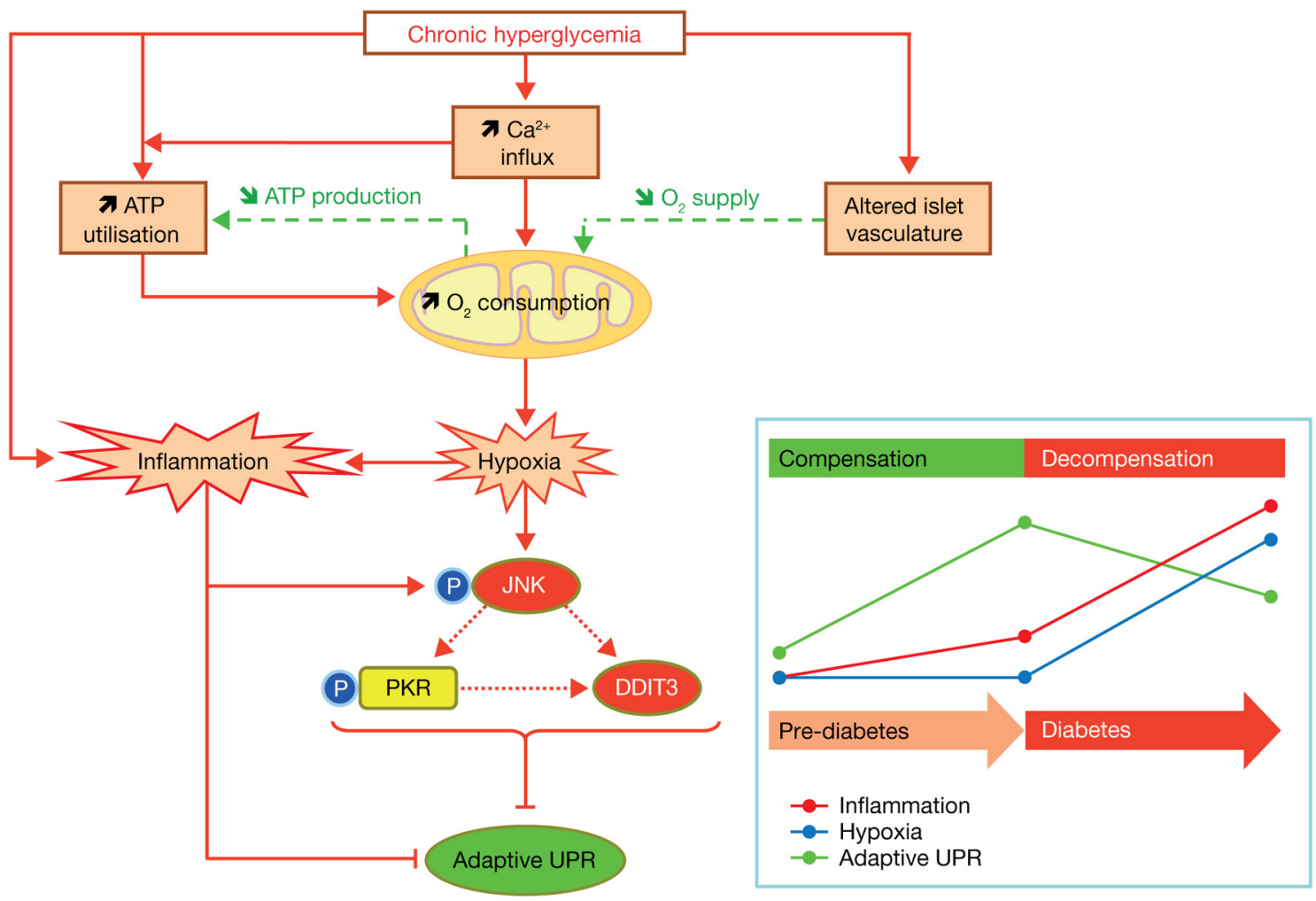

\section{Figure 4}

Schematic representation of the role of hypoxia and inflammation in the loss of adaptive UPR under chronic hyperglycemia. Under chronic hyperglycemia, the acceleration of mitochondrial metabolism and the stimulation of ATP consuming cellular processes, increases $\beta$-cell $\mathrm{O}_{2}$ consumption. On the other hand, chronic hyperglycemia negatively affects islet vasculature thereby resulting in reduced $\mathrm{O}_{2}$ supply. These events lead to $\beta$-cell hypoxia and activation of downstream pathways including c-Jun N-terminal kinase (JNK), double-stranded RNA-dependent protein kinase (PKR) and downstream DNA damage inducible transcript 3 (DDIT3). Activation of these effectors plays an important role in the inhibition of the adaptive unfolded protein response (UPR) under hypoxia. Inflammation induced by chronic hyperglycemia, but also by hypoxia, can also increase JNK phosphorylation and has been proposed to play a role in the failure of adaptive UPR. The timing of these complex events is represented in the insert. In the prediabetic phase ( $\beta$-cell compensation), the UPR is markedly upregulated in parallel with a moderate activation of inflammatory signaling in the absence of signs of islet hypoxia. However, in the diabetic phase ( $\beta$-cell decompensation), the adaptive UPR declines concomitantly with strong upregulation of inflammatory and hypoxia-response genes. 
hypoxia-response genes were upregulated in the islets of diabetic, but not prediabetic, $d b / d b$ mice in an inverse relationship with UPR gene expression (Fig. 4). We have demonstrated that hypoxia inhibits the adaptive UPR specifically in $\beta$-cells and that this inhibition was associated with impaired ER-to-Golgi protein trafficking and was implicated in increased apoptosis under hypoxic stress. These effects were mediated by the activation of JNK and Ddit3, but were independent of hypoxiainducible factor $1 \alpha(\mathrm{HIF} 1 \alpha)$ (Bensellam et al. 2016) (Fig. 4). Interestingly, JNK activation has also been observed in the islets of diabetic $d b / d b$ mice and its inhibition increased adaptive UPR gene expression and reduced apoptosis (Chan et al. 2015).

In addition to hypoxia, inflammation is another potential mechanism that may be involved in UPR inactivation (Fig. 4). T2D is characterized by a low-grade inflammation and proinflammatory cytokines released by immune cells, endothelial cells and adipose tissue under chronic hyperglycemia have been proposed to contribute to islet inflammation and $\beta$-cell dedifferentiation (Donath \& Shoelson 2011, Nordmann et al. 2017). Interestingly, cytokine treatment of mouse islets downregulated the mRNA levels of several adaptive UPR genes including Hspa5, Hsp90b1, Fkbp11 and Dnajc3 (Chan et al. 2011). Importantly, the progression towards diabetes in $d b / d b$ mice was accompanied by a progressive upregulation of inflammatory genes including Il6, Il1 $\beta, C x c l 1, T n f \alpha, C c l 2$ and the macrophages marker gene $C d 68$ (Fig. 4). This inflammatory signature was however absent in the islets of $o b / o b$ mice (Chan et al. 2013). Moreover, assessment of timedependent changes in XBP1s and ATF6 protein expression in the islets of mouse models of type 1 diabetes (T1D), which is an immune-mediated disease, revealed a progressive downregulation. These alterations were also observed on pancreatic section of humans T1D donors (Engin et al. 2013). Of note, hypoxia also upregulated inflammatory genes in mouse islets (Bensellam et al. 2016) (Fig. 4). Altogether, these observations suggest a role for inflammatory signalling in the downregulation of the adaptive UPR in T2D.

Very interestingly, in rat models of hypertrophic and failing heart, myocardial XBP1s and HSPA5 protein levels were upregulated in the early phase of the disease (adaptive phase) but declined in the late phase (maladaptive phase), very similarly to what has been observed in $d b / d b$ mouse islets. In the cardiac context, it has been shown that miR-30-p3 family and miR-214 were implicated in XBP1s downregulation (Duan et al. 2015). Likewise, miRNAs may also be involved in UPR inactivation in $\beta$-cells. The expression of various miRNAs is affected in prediabetic and diabetic $d b / d b$ mouse islets in comparison to their age-matched lean controls (Nesca et al. 2013), and miR-200 has been shown to negatively regulate Dnajc3 expression (Belgardt et al. 2015). Studies comparing the time-dependent changes in miRNA expression in obese models of $\beta$-cell compensation and decompensation are needed to shed more light on this possibility.

In sum, there is growing evidence that failure of the adaptive UPR in T2D is linked with $\beta$-cell dedifferentiation and dysfunction. Our evidence strongly supports the implication of hypoxia and very likely inflammatory signalling in UPR inactivation. But how the inactivation of the UPR could affect the differentiated $\beta$-cell phenotype is unclear at this stage. One possibility is that failure of the adaptive UPR exacerbates hyperglycemia-induced oxidative stress. Not only is the role of the latter in $\beta$-cell dedifferentiation well established, but oxidative stress is also linked with ER stress. Indeed, defective ER protein folding machinery and subsequent accumulation of unfolded proteins in the ER has been shown to trigger oxidative stress and damage in association with altered $\beta$-cell differentiation (Back et al. 2009, Han et al. 2015). Moreover, expression of a mutant form of proinsulin that is prone to misfolding in Akita mouse islets has also been associated with increased oxidative stress and damage (Yuan et al. 2012). Furthermore, treatment of glucose-infused rats with chemical chaperones reduced islet superoxide anion generation and preserved $\beta$-cell function (Tang et al. 2012). Thus, it is postulated that the inactivation of the UPR in T2D leads to progressive accumulation of unfolded proteins in the ER; this potentiates hyperglycemia-induced reactive oxygen species (ROS) production and oxidative stress, which leads to a gradual loss of $\beta$-cell identity. Future work in this field is needed to verify this hypothesis and explore the mechanism(s) by which protein misfolding in the ER induces/aggravates oxidative stress and whether a crosstalk between the ER and mitochondria may be involved.

\section{Upregulation of $\beta$-cell forbidden genes}

As well as the downregulation of $\beta$-cell-enriched genes (addressed above), $\beta$-cell dedifferentiation in T2D features upregulation of genes that are either suppressed or expressed at very low levels in mature $\beta$-cells under physiological conditions. These genes that we term as $\beta$-cell forbidden genes enclose various types including metabolic genes, transcriptional regulators, signalling effectors and stress response genes (Table 3 and Bensellam et al. 2012b). Upregulation of these genes under hyperglycemia has important consequences on $\beta$-cell identity and function. 


\begin{tabular}{l|l|l|c|c|}
$\begin{array}{l}\text { Journal of } \\
\text { Endocrinology }\end{array}$ & $\begin{array}{l}\text { M-cell dedifferentiation in } \\
\text { diabetes }\end{array}$ & $\mathbf{2 3 6 : 2}$ & $\mathbf{R} 127$ \\
\hline
\end{tabular}

Table 3 Upregulation of $\beta$-cell forbidden genes under glucotoxicity.

\begin{tabular}{|c|c|c|c|c|}
\hline \multirow[b]{2}{*}{ Genes } & \multicolumn{2}{|l|}{ Glucotoxicity model } & \multirow{2}{*}{$\begin{array}{l}\text { Confirmation } \\
\text { in human T2D }\end{array}$} & \multirow[b]{2}{*}{ Glucotoxic effect } \\
\hline & In vitrolex vivo & In vivo & & \\
\hline \multicolumn{5}{|c|}{ Transcriptional regulators } \\
\hline$C / E B P \beta$ & $\begin{array}{l}\text { HIT-T15 cells (Lu et al. 1997) } \\
\text { INS1 cells (Lu et al. 1997) }\end{array}$ & $\begin{array}{l}\text { Px rat islets (Seufert et al. 1998) } \\
\text { ZDF rat islets (Seufert et al. 1998) }\end{array}$ & & $\begin{array}{l}\text { mRNA and } \\
\text { protein }\end{array}$ \\
\hline Crem & $\begin{array}{l}\text { Wistar and Sprague-Dawley } \\
\text { rat islets (Bensellam et al. } \\
\text { 2009, Zhou et al. 2003) }\end{array}$ & & & mRNA \\
\hline Myc & $\begin{array}{l}\text { Wistar rat islets (Bensellam } \\
\text { et al. 2009, Elouil et al. } \\
\text { 2005, Kaneto et al. 2002a) }\end{array}$ & $\begin{array}{l}\text { Px rat islets (Jonas et al. 2001, Jonas et al. } \\
\text { 1999) } \\
\text { Gk rat islets (Lacraz et al. 2010) }\end{array}$ & & mRNA \\
\hline $\mid d 1$ & $\begin{array}{l}\text { Human islets (Wice et al. } \\
\text { 2001) }\end{array}$ & $\begin{array}{l}d b / d b \text { mouse islets (Kjorholt et al. 2005, } \\
\text { Chan et al. 2013, Bensellam et al. 2015) }\end{array}$ & & $\begin{array}{l}\text { mRNA and } \\
\text { protein }\end{array}$ \\
\hline$I d 2$ & & $\begin{array}{l}\text { GK rat islets (Homo-Delarche et al. 2006) } \\
d b / d b \text { mouse islets (Bensellam et al. 2015) }\end{array}$ & & mRNA \\
\hline$I d 3$ & & $d b / d b$ mouse islets (Bensellam et al. 2015) & & $\begin{array}{l}\text { mRNA and } \\
\text { protein }\end{array}$ \\
\hline Id4 & & $d b / d b$ mouse islets (Bensellam et al. 2015) & & mRNA \\
\hline Ngn3 & & $\begin{array}{l}d b / d b \text { mouse islets (Talchai et al. 2012) } \\
\mathrm{K}_{\text {ATP-GOF mice (Wang et al. 2014) }} \text { GIRO mouse islets (Talchai et al. 2012) } \\
\text { GIRKO } \\
\text { Multiparous and ageing FoxO1-KO mice } \\
\text { (Talchai et al. 2012) }\end{array}$ & & Protein \\
\hline Nanog & & $\begin{array}{l}\text { Multiparous FoxO1-KO mice (Talchai } \\
\text { et al. 2012) }\end{array}$ & & Protein \\
\hline Oct4 & & $\begin{array}{l}\text { db/db mouse islets (Talchai et al. 2012) } \\
\text { GIRKO mouse islets (Talchai et al. 2012) } \\
\text { Multiparous FoxO1-KO mice (Talchai } \\
\text { et al. 2012) }\end{array}$ & & Protein \\
\hline$L-M y c$ & & $\begin{array}{l}d b / d b \text { mouse islets (Talchai et al. 2012) } \\
\text { GIRKO mouse islets (Talchai et al. 2012) } \\
\text { Multiparous FoxO1-KO mice (Talchai } \\
\text { et al. 2012) }\end{array}$ & & Protein \\
\hline Sox9 & & & $\begin{array}{l}\text { Yes: (Marselli } \\
\text { et al. 2010, } \\
\text { Bugliani } \\
\text { et al. 2013) }\end{array}$ & mRNA \\
\hline \multicolumn{5}{|c|}{ Metabolic genes } \\
\hline$H k 1$ & & $\begin{array}{l}\text { Px rat islets (Jonas et al. 1999) } \\
\text { ZDF rat islets (Cockburn et al. 1997) } \\
\text { db/db mouse islets (Kjorholt et al. 2005) } \\
\text { Psammomys obesus (Nesher et al. 1999) }\end{array}$ & & $\begin{array}{l}\text { mRNA and } \\
\text { enzymatic } \\
\text { activity }\end{array}$ \\
\hline$H k 2$ & $\begin{array}{l}\text { Rat islets (Ghanaat-Pour et al. } \\
\text { 2007) }\end{array}$ & & & mRNA \\
\hline G6pase & & $\begin{array}{l}\text { Px rat islets (Laybutt et al. 2002b) } \\
\text { GK rat islets (Ling et al. 2001) }\end{array}$ & & $\begin{array}{l}\text { mRNA and } \\
\text { enzymatic } \\
\text { activity }\end{array}$ \\
\hline Fbp 1 & & Px rat islets (Laybutt et al. 2002b) & & mRNA \\
\hline Pck1 & $\begin{array}{l}\text { Human islets (Shalev et al. } \\
\text { 2002) }\end{array}$ & & $\begin{array}{l}\text { Yes: (Marselli } \\
\text { et al. 2010) }\end{array}$ & mRNA \\
\hline Ldha & $\begin{array}{l}\text { Wistar rat islets (Bensellam } \\
\text { et al. 2009, Bensellam et al. } \\
\text { 2012a) }\end{array}$ & $\begin{array}{l}\text { Px rat islets (Jonas et al. 1999, Laybutt } \\
\text { et al. 2003) } \\
\text { GK rat islets (Homo-Delarche et al. 2006, } \\
\text { Sasaki et al. 2013) } \\
\text { ZDF rat islets (Li et al. 2006b) } \\
\text { Rat islets transplanted into diabetic rats } \\
\text { (Laybutt et al. 2007) }\end{array}$ & $\begin{array}{l}\text { Yes: (Marselli } \\
\text { et al. 2010) }\end{array}$ & $\begin{array}{l}\text { mRNA, protein } \\
\text { and lactate } \\
\text { production }\end{array}$ \\
\hline Mct1 & & Px rat islets (Laybutt et al. 2002b) & & mRNA \\
\hline Mct2 & & Px rat islets (Laybutt et al. 2002b) & & mRNA \\
\hline
\end{tabular}


Table 3 Continued.

\begin{tabular}{|c|c|c|c|c|}
\hline \multirow[b]{2}{*}{ Genes } & \multicolumn{2}{|l|}{ Glucotoxicity model } & \multirow{2}{*}{$\begin{array}{l}\text { Confirmation } \\
\text { in human T2D }\end{array}$} & \multirow[b]{2}{*}{ Glucotoxic effect } \\
\hline & In vitrolex vivo & In vivo & & \\
\hline Mct4 & $\begin{array}{l}\text { Wistar rat islets (Bensellam } \\
\text { et al. 2012a) }\end{array}$ & Px rat islets (Laybutt et al. 2002b) & & mRNA \\
\hline Ucp2 & $\begin{array}{l}\text { Wistar rat islets (Khaldi et al. } \\
\text { 2004) }\end{array}$ & $\begin{array}{l}\text { Glucose-infused rats (Kassis et al. 2000) } \\
\text { Px rat islets (Laybutt et al. 2002b) } \\
\text { ZDF rat islets (Oberkofler et al. 2009) } \\
d b / d b \text { mouse islets (Kjorholt et al. 2005) } \\
\text { ob/ob mouse islets (Zhang et al. 2001) }\end{array}$ & & $\begin{array}{l}\text { mRNA and } \\
\text { protein }\end{array}$ \\
\hline Acot7 & & ZDF rat islets (Parton et al. 2006) & $\begin{array}{l}\text { Yes: (Marselli } \\
\text { et al. 2010) }\end{array}$ & mRNA \\
\hline Aldh1a3 & & $\begin{array}{l}d b / d b \text { mouse islets (Ishida et al. 2017, } \\
\text { Kim-Muller et al. 2016) } \\
\text { Abcc8-KO mice (Stancill et al. 2017) }\end{array}$ & $\begin{array}{l}\text { Yes: (Cinti } \\
\text { et al. 2016) }\end{array}$ & $\begin{array}{l}\text { mRNA, protein } \\
\text { and enzymatic } \\
\text { activity }\end{array}$ \\
\hline
\end{tabular}

Metabolic genes A major earlier and recent focus in this field has been on metabolic genes, in particular Ldha and Mct1. Pioneering studies have shown that LDHA activity is markedly lower in $\beta$-cells in comparison to other islet cells, exocrine cells and hepatocytes (Hellman \& Taljedal 1967, Sekine et al. 1994). Ensuing large-scale studies comparing gene expression patterns of different mouse tissues with pancreatic islets confirmed low expression of Ldha and Mct1 and identified other $\beta$-cell forbidden genes (Pullen et al. 2010, Thorrez et al. 2011). Interestingly, Ldha and various Mct isoform genes were upregulated in the islets of rodent models of hyperglycemia and diabetes (Jonas et al. 1999, Laybutt et al. 2002b, 2007, HomoDelarche et al. 2006, Li et al. 2006b). Upregulation of Ldha has also been reported in $\beta$-cells of human T2D subjects (Marselli et al. 2010) (Table 3). The role of hyperglycemia in this induction has been demonstrated by phlorizin treatment experiments in Px rats (Jonas et al. 1999, Laybutt et al. 2002b). In addition, we have previously reported upregulation of Ldha mRNA levels, along with other glycolytic and hypoxia-response genes, in cultured rat islets exposed to elevated glucose levels (Bensellam et al. 2009). The prevention of this induction by hyperoxia suggested an implication of high glucose-induced $\beta$-cell hypoxia and activation of HIF $1 / 2 \alpha$ (Bensellam et al. 2012a). Another pathway implicating oxidative stress may be involved in LDHA induction in the islets of GK rats (Sasaki et al. 2013). Evidence has also shown a role of miRNAs in the regulation of Mct1 expression (Pullen et al. 2011, Martinez-Sanchez et al. 2015). But whether altered expression of specific miRNAs in T2D is involved in the upregulation of Mct1 requires further proof. Upregulation of Ldha and Mct genes may alter $\beta$-cell function by diverting the glycolytic flux from mitochondrial pyruvate oxidation to lactate production and transport. This could alter glucose homeostasis by sensitising $\beta$-cells to secrete insulin in response to non-physiological stimuli (Ishihara et al. 1999, Ainscow et al. 2000, Otonkoski et al. 2007, Pullen et al. 2012).

As explained in 'Relationship of $\beta$-cell differentiation to insulin secretory function' section, the repression of high-affinity type I-III hexokinases in $\beta$-cells prevents insulin release in response to low non-stimulatory glucose levels such as in the fasted state (Sekine et al. 1994, Schuit et al. 1999). In the context of diabetes, increased mRNA levels of $H k 1$ have been reported in Px rats and $d b / d b$ mouse islets (Jonas et al. 1999, Kjorholt et al. 2005). In agreement, HK enzymatic activity was upregulated in the islets of ZDF rats (Cockburn et al. 1997), DBA/2 mice (Kooptiwut et al. 2002) and Psammomys obesus on high energy diet (Nesher et al. 1999). Moreover, exposure of rat islets to elevated glucose levels in vitro upregulated the mRNA levels of Hk2 (Ghanaat-Pour et al. 2007) (Table 3). Upregulation of $H k s$, and likely other glycolytic genes, may explain the reduced threshold glucose concentration for the stimulation of insulin secretion (glucose hypersensitivity) observed in INS1 cells (Roche et al. 1997), rat and mouse islets (Khaldi et al. 2004, Bensellam et al. 2009, Pascal et al. 2010) and purified rat and human $\beta$-cells (Ling \& Pipeleers 1996, Ling et al. 1996) cultured in the presence of supraphysiological glucose levels, as well as in the islets of animal models of diabetes, including glucose-infused rats (Ammon et al. 1998), Px rats (Leahy et al. 1993, Hosokawa et al. 1995), ZDF rats (Tokuyama et al. 1995), ob/ob mice (Chen et al. 1993) and Psammomys obesus (Pertusa et al. 2002). In support of this hypothesis, overexpression of Hk1 in MIN6 cells and primary rat islets has been shown to increase the basal glycolytic flux and insulin release along with altered GSIS (Becker et al. 1994, Ishihara et al. 1994). 
Other metabolic genes presenting low expression under physiological conditions and upregulated in diabetes include the gluconeogenic genes G6pase (Ling et al. 2001, Laybutt et al. 2002b), Fbp1 (Laybutt et al. 2002b) and Pck1 (Marselli et al. 2010). The latter gene was also upregulated in isolated human islets cultured in the presence of high glucose levels (Shalev et al. 2002) (Table 3). Upregulation of G6pase may divert glucose from its classical metabolic route by inducing glucose cycling (GC). GC is a futile cycle where glucose is phosphorylated to glucose-6-phosphate by GCK and then dephosphorylated to glucose by glucose-6-phosphatase (G6Pase) with consumption of an ATP molecule. Indeed, G6pase overexpression in INS1 cells has been shown to increase GC and reduce GSIS (Trinh et al. 1997). Upregulation of G6pase mRNA and enzymatic activity in the islets of Px and GK rats was reversed by phlorizin treatment thereby underscoring the role of hyperglycemia (Ling et al. 2001, Laybutt et al. 2002b).

Another $\beta$-cell forbidden gene, Acot7 (Pullen et al. 2010), which encodes for mitochondrial and cytosolic isoforms of acyl-CoA thioesterase 7 (ACOT7), hydrolyses long-chain acyl-CoA esters. Its expression was upregulated in the islets of ZDF rats and $\beta$-cells of human T2D patients (Parton et al. 2006, Marselli et al. 2010) (Table 3). Interestingly, repression of Acot7 in mouse has been proposed in a recent study to be necessary for adequate insulin secretion. Indeed, selective overexpression of the mitochondrial Acot7 in $\beta$-cells of adult mice impaired glucose tolerance as a consequence of altered insulin secretion (Martinez-Sanchez et al. 2016). However, further work is needed to determine the precise mechanism(s) involved.

Recently, Aldh1a3 has been proposed as a novel $\beta$-cell forbidden gene and putative marker of dedifferentiated $\beta$-cells (Kim-Muller et al. 2016). Aldehyde dehydrogenase family 1 member A3 (ALDH1A3) expression and activity were upregulated in the islets of various animal models including $d b / d b$ mice (Kim-Muller et al. 2016, Ishida et al. 2017, Stancill et al. 2017). Increased ALDH1A3 immunostaining has also been confirmed in the islets of diabetic human subjects and was associated in some $\beta$-cells with cytoplasmic expression of NKX6.1 (Cinti et al. 2016) (Table 3). However, overexpression of Aldh1a3 in MIN6 cells did not alter the expression of $\beta$-cell-enriched genes and was even associated in mouse islets with a slight potentiation of GSIS thereby ruling out a causative role of ALDH1A3 in $\beta$-cell dedifferentiation (Kim-Muller et al. 2016). Aldh1a3 is a detoxifying enzyme that catalyses the oxidation of retinal to retinol using $\mathrm{NAD}^{+}$. It is also involved in other metabolic processes including amino acid metabolism and the metabolism of lipid peroxidation products (Duan et al. 2016). Therefore, its upregulation in the islets of diabetic animals and T2D subjects could be a response to oxidative stress and the ensuing damage.

Transcriptional regulators Besides metabolic genes, $\beta$-cell forbidden genes also enclose transcriptional regulators. We have described in 'Down regulation of insulin gene expression' section the role of C/EBP $\beta$, MYC and ETS1 in the alteration of insulin gene expression. In addition, several transcription factors typically expressed in progenitor cells at the embryonic stage and repressed in adult $\beta$-cells were upregulated in $\beta$-cells of various diabetic animal models, including neurogenin 3 (NGN3), nanog homeobox (NANOG), octamer-binding transcription factor 4 (OCT4 also known as POU5F1) and v-myc avian myelocytomatosis viral oncogene homolog 1, lung carcinoma derived (L-Myc) (Talchai et al. 2012, Brereton et al. 2014, Wang et al. 2014) (Table 3). Lineage trancing studies confirmed that these dedifferentiated cells originate from cells that expressed insulin and also suggested their transdifferentiation in other islet non- $\beta$-cells, including $\alpha$-cells (Talchai et al. 2012, Wang et al. 2014) (Fig. 2). Interestingly, NGN3 reexpression in the islets of a diabetic mouse model with $\mathrm{K}_{\mathrm{ATP}}$ channel mutation was reversed by insulin therapy (Wang et al. 2014). This observation is of importance. Together with the phlorizin and caloric restriction studies mentioned in previous sections, these reports highlight the astonishing plasticity of the $\beta$-cell phenotype and indicate the possibility to reverse $\beta$-cell dedifferentiation, at least in rodents. Furthermore, a recent study has also shown the possibility to prevent downregulation of some $\beta$-cell key transcription factor genes in vitro under cytokine treatment and in vivo in $d b / d b, o b / o b$ and Akita mice using small-molecule inhibitors of the tumour growth factor $\beta$ (TGF $\beta$ ) pathway that target the TGF $\beta$ receptor I (also known as ALK5) (Blum et al. 2014). In humans, to date and to our knowledge, there is no confirmation of such expression of endocrine progenitor transcription factors in $\beta$-cells of T2D patients, except for upregulation of POU5F1 mRNA levels (Guo et al. 2013). However, two studies have reported increased mRNA levels of the pre-endocrine gene SOX9 (Marselli et al. 2010, Bugliani et al. 2013). Evidence suggests that SOX9 upregulation in T2D may result from hypoxia and activation of HIF1 and could play a role in the downregulation of $\beta$-cellenriched genes (Puri et al. 2013). 
Inhibitor of differentiation (ID) proteins are another class of transcriptional regulators induced in response to glucose stimulation in $\beta$-cell lines and human islets (Wice et al. 2001) and upregulated in the islets of diabetic $d b / d b$ mice and GK rats (Kjorholt et al. 2005, Homo-Delarche et al. 2006, Bensellam et al. 2015) (Table 3). They have been proposed to act as repressors of basic helix-loophelix (bHLH) transcription factors thereby modulating cell differentiation and proliferation (Lasorella et al. 2014, Nair et al. 2014). Upregulation of $I d 1$ under high-fat diet has been implicated in the inhibition of insulin secretion and alteration of glucose homeostasis (Akerfeldt \& Laybutt 2011). We have subsequently demonstrated that IDs are a novel class of oxidative stress-responsive genes in $\beta$-cells. Surprisingly, under oxidative stress conditions, deletion of $I d 1$ and/or $I d 3$ resulted in mitochondrial impairment and induced a global attenuation of antioxidant gene expression in association with a further increase in intracellular ROS levels and apoptosis. These effects involved a novel interaction of IDs with the NFE2L2small Mafs antioxidant pathway (Bensellam et al. 2015). These findings suggest that IDs are key components of the antioxidant response and play an important role in the promotion of $\beta$-cell survival under oxidative stress. However, these observations also raise the question of whether dedifferentiation could be an adaptive mechanism to escape cell death under stress conditions (discussed in the next section).

Stress response genes Chronic hyperglycemia exposes $\beta$-cells to higher levels of stress than under physiological conditions. To face such threat, $\beta$-cells upregulate endogenous stress responses to uphold homeostasis. Thus, the induction and the regulatory mechanisms of the antioxidant and the ER stress responses have received much attention given the important role of these pathways in $\beta$-cell pathophysiology (reviewed in Bensellam et al. $2012 b$ ). We have described in 'Failure of the adaptive UPR and progression towards diabetes' section the regulation of the UPR in diabetes and the emerging evidence linking the failure of this response with the progression towards diabetes and $\beta$-cell dedifferentiation. In the following paragraphs, we will focus on the antioxidant response and its potential implication in $\beta$-cell dedifferentiation.

Upregulation of antioxidant gene expression in response to elevated glucose levels has been well documented in vitro and in diabetic animals, and has also been confirmed in human T2D for some antioxidant genes (reviewed in Bensellam et al.2012b). The primary role of the antioxidant response is to relieve hyperglycemia-induced oxidative stress and promote cell survival. Nevertheless, $\beta$-cell mass is reduced by about $60 \%$ in GK rats although the mRNA and protein levels of $\mathrm{Nfe} 2 \mathrm{l} 2$ and several other antioxidant genes were markedly upregulated (Movassat et al. 1997, Lacraz et al. 2009). Moreover, the $\beta$-cell differentiated phenotype is noticeably altered in Px rats despite strong upregulation of the mRNA levels of Hmox1 and Gpx1 (Jonas et al. 1999, Laybutt et al. 2002a). Similarly, $\beta$-cell mass is reduced in human T2D patients even with upregulated mRNA levels of several antioxidant genes including various isoforms of metallothioneins (Marchetti et al. 2004, Marselli et al. 2010). These observations suggest that either the endogenous antioxidant response triggered by hyperglycemia is not robust enough to efficiently protect the $\beta$-cell differentiated phenotype or its strong and sustained activation under chronic hyperglycemia is deleterious and may play a role in $\beta$-cell dedifferentiation.

In support of the first possibility, previous evidence has shown that rat islets express low levels of several antioxidant genes in comparison to other tissues (Lenzen et al. 1996, Tiedge et al. 1997). The $\mathrm{H}_{2} \mathrm{O}_{2}$ detoxifying enzyme catalase is specifically repressed in adult mouse $\beta$-cells in comparison to other tissues (Thorrez et al. 2011, Pullen et al. 2017). Lower GPX1 expression and activity has also been confirmed in isolated human islets (Tonooka et al. 2007). In highly metabolically active $\beta$-cells, such low antioxidant gene expression signature is undoubtedly an Achilles' heel, especially under prolonged hyperglycemia. Interestingly, $\beta$-cell-specific overexpression of Gpx1 in $d b / d b$ mice prevented the loss of the $\beta$-cell-enriched genes MAFA, NKX6.1 and GLUT2 (Harmon et al. 2009, Guo et al. 2013). Similarly, antioxidant supplementation has been proven beneficial, at least in vitro and in rodent models (reviewed in Bensellam et al. 2012b). Why $\beta$-cells exhibit lower antioxidant gene expression in comparison to other tissues is unclear. However, some studies have proposed that physiological levels of $\mathrm{H}_{2} \mathrm{O}_{2}$ may play the role of a coupling factor for GSIS (Pi et al. 2007, Leloup et al. 2009). In addition, it has been shown that catalase or metallothionein overexpression in $\beta$-cells, while reducing cytokine-induced ROS generation, accelerated diabetes onset in male NOD mice in association with increased $\beta$-cell death and reduced PDX1 protein levels (Li et al. $2006 a$ ). It should be emphasized here that the antioxidant arsenal of $\beta$-cells is not limited to the classically studied genes such as Gpx1 and catalase but encloses many other players including those of the glutathione system, the peroxiredoxin system, the thioredoxin system, haem oxygenases and metallothioneins and many of these genes are either expressed at high levels under 
basal conditions or markedly upregulated under stress (Bensellam et al. 2009). The scenery is even more complex as some antioxidant genes can play other roles and be involved in different cellular processes such as the zinc buffering properties of metallothioneins (Chabosseau \& Rutter 2016) or the involvement in iron metabolism for Hmox1 (Gozzelino \& Soares 2014). Therefore, one may propose that sustained upregulation of this wide battery of antioxidant genes under chronic hyperglycemia may exert a negative impact on the $\beta$-cell differentiated phenotype by yet to be defined mechanisms.

\section{Dedifferentiation as a potential adaptive mechanism}

Despite marked alteration of the $\beta$-cell differentiated phenotype and reduction of $\beta$-cell mass in human T2D, the $\beta$-cell apoptosis rate remains relatively low. This phenomenon is also observed in experimental models such as Px rats, $d b / d b$ mice, Foxo1-KO mice and $\mathrm{K}_{\mathrm{ATP}^{-}}$ GOF mice. An emerging body of data suggests that $\beta$-cell dedifferentiation could be an adaptive mechanism to escape cell death under chronic hyperglycemia at the price of altered identity and function.

As mentioned in the previous section, we found that upregulation of IDs (inhibitors of bHLH transcription factors) during oxidative stress played a key role in maintaining the antioxidant response and mitochondrial integrity and thereby promoting $\beta$-cell survival (Bensellam et al. 2015). In addition, previous reports have shown that $\beta$-cell line maturation from a glucagon-producing phenotype to an insulin-producing phenotype was associated with increased sensitivity to several toxic agents such as cytokines, streptozotocin and alloxan (Nielsen et al. 1999). Further studies revealed an important role of increased expression of $P d x 1$ and $N k x 6.1$ in this acquired sensitivity (Nielsen et al. 2004). The potential link between dedifferentiation and adaptation/resistance to stress seems to be a conserved biological mechanism that has also been described in other cell types and models including cancer cells (Del Vecchio et al. 2014, Li et al. 2016, Roesch et al. 2016) and even plant cells (Grafi \& Barak 2015). Future work is needed to validate this hypothesis in $\beta$-cells and to fully characterize the response of dedifferentiated $\beta$-cells to different types of stress.

From a therapeutic perspective, alleviating $\beta$-cell stress may provide a novel strategy to reverse the process of dedifferentiation and restore functional $\beta$-cell mass. Previous $\beta$-cell rest approaches have shown promising results in vitro and in animal models (Grill et al. 2009). Noteworthy, in isolated rat islets, high glucose-induced upregulation of several $\beta$-cell forbidden genes and other stress response genes such as Ldha, Crem, Myc, Adm and Hmox 1 was markedly prevented by diazoxide treatment (Jonas et al. 2001, 2003, Ma et al. 2007). However, until now, these methods failed to improve glycemic control in T2D patients (reviewed in Bensellam et al. 2012b). Given the key role of hyperglycemia in $\beta$-cell dedifferentiation and the demonstrated beneficial effects of the glucose lowering strategies in rodents, SGLT2 inhibition by gliflozins merits further attention in humans (AbdulGhani et al. 2017). The use of these drugs in combination with other therapies such as incretins may exert beneficial effects on the $\beta$-cell phenotype (Busch \& Kane 2017, Kaneto et al. 2017). The potential combination with antioxidants such as GPX mimetics and/or chemical chaperones such as the recently identified small-molecule azoramide (Fu et al. 2015) merits further experimental and clinical testing.

\section{Conclusion}

Growing evidence indicates that $\beta$-cell dedifferentiation plays a key role in the loss of functional $\beta$-cell mass in T2D. Over the last decades, in vitro and animal studies implicated glucotoxicity and downstream pathways in this process. Dysregulation of numerous - and not fully identified transcriptional regulators, genes, miRNAs, stress responses, metabolic processes and epigenetic mechanisms converge to compromise $\beta$-cell identity in T2D. Based on emerging data and observations in other cell types and models, we proposed that $\beta$-cell dedifferentiation could be an adaptive mechanism to escape cell death under stress conditions. Interestingly, animal studies suggest the possibility to reverse $\beta$-cell dedifferentiation by reducing $\beta$-cell stress strategies. More large-scale studies using human $\beta$-cells are needed to validate the findings in rodents and shed more light on the different signalling effectors and pathways involved in the alteration of the $\beta$-cell differentiated phenotype. A better understanding of the physiological and pathological regulation of these pathways may pave the way to reverse $\beta$-cell dedifferentiation and restore the functional $\beta$-cell mass in human T2D.

\section{Supplementary data}

This is linked to the online version of the paper at https://doi.org/10.1530/ JOE-17-0516. 


\section{Declaration of interest}

The authors declare that there is no conflict of interest that could be perceived as prejudicing the impartiality of this review.

\section{Funding}

M B is supported by a MOVE-in Louvain/EC Marie-Curie incoming postdoctoral fellowship. J C J is Research Director of the Fonds de la Recherche Scientifique-FNRS, Belgium. D R L is supported by an Australian Research Council (ARC) Future Fellowship and grants from the National Health and Medical Research Council (NHMRC) of Australia and the Diabetes Australia Research Program.

\section{References}

Abdul-Ghani M, Al Jobori H, Daniele G, Adams J, Cersosimo E, Triplitt C \& DeFronzo RA 2017 Inhibition of renal sodium-glucose cotransport with empagliflozin lowers fasting plasma glucose and improves betacell function in subjects with impaired fasting glucose. Diabetes $\mathbf{6 6}$ 2495-2502. (https://doi.org/10.2337/db17-0055)

Ainscow EK, Zhao C \& Rutter GA 2000 Acute overexpression of lactate dehydrogenase-A perturbs $\beta$-cell mitochondrial metabolism and insulin secretion. Diabetes 49 1149-1155. (https://doi.org/10.2337/ diabetes.49.7.1149)

Akerfeldt MC \& Laybutt DR 2011 Inhibition of Id1 augments insulin secretion and protects against high-fat diet-induced glucose intolerance. Diabetes 60 2506-2514. (https://doi.org/10.2337/db11-0083)

Alarcon C, Boland BB, Uchizono Y, Moore PC, Peterson B, Rajan S, Rhodes OS, Noske AB, Haataja L, Arvan P, et al. 2016 Pancreatic betaCell adaptive plasticity in obesity increases insulin production but adversely affects secretory function. Diabetes 65 438-450. (https://doi. org/10.2337/db15-0792)

Allagnat F, Christulia F, Ortis F, Pirot P, Lortz S, Lenzen S, Eizirik DL \& Cardozo AK 2010 Sustained production of spliced X-box binding protein 1 (XBP1) induces pancreatic beta cell dysfunction and apoptosis. Diabetologia 53 1120-1130. (https://doi.org/10.1007/ s00125-010-1699-7)

Ammon HP, Bacher M, Brandle WF, Waheed A, Roenfeldt M, el-Sayed ME, Ahmed AA \& Wahl MA 1998 Effect of forty-eight-hour glucose infusion into rats on islet ion fluxes, ATP/ADP ratio and redox ratios of pyridine nucleotides. Journal of Endocrinology 156 583-590. (https://doi.org/10.1677/joe.0.1560583)

Asplund K, Westman S \& Hellerstrom C 1969 Glucose stimulation of insulin secretion from the isolated pancreas of foetal and newborn rats. Diabetologia 5 260-262. (https://doi.org/10.1007/BF01212095)

Axelsson AS, Mahdi T, Nenonen HA, Singh T, Hanzelmann S, Wendt A, Bagge A, Reinbothe TM, Millstein J, Yang X, et al. 2017 Sox5 regulates beta-cell phenotype and is reduced in type 2 diabetes. Nature Communications 8 15652. (https://doi.org/10.1038/ncomms15652)

Back SH, Scheuner D, Han J, Song B, Ribick M, Wang J, Gildersleeve RD, Pennathur S \& Kaufman RJ 2009 Translation attenuation through eIF2alpha phosphorylation prevents oxidative stress and maintains the differentiated state in beta cells. Cell Metabolism 10 13-26. (https://doi.org/10.1016/j.cmet.2009.06.002)

Becker TC, BeltrandelRio H, Noel RJ, Johnson JH \& Newgard CB 1994 Overexpression of hexokinase I in isolated islets of Langerhans via recombinant adenovirus. Enhancement of glucose metabolism and insulin secretion at basal but not stimulatory glucose levels. Journal of Biological Chemistry $26921234-21238$.

Belgardt BF, Ahmed K, Spranger M, Latreille M, Denzler R, Kondratiuk N, von Meyenn F, Villena FN, Herrmanns K, Bosco D, et al. 2015 The microRNA-200 family regulates pancreatic beta cell survival in type
2 diabetes. Nature Medicine 21 619-627. (https://doi.org/10.1038/ $\mathrm{nm} .3862$ )

Ben-Shushan E, Marshak S, Shoshkes M, Cerasi E \& Melloul D 2001 A pancreatic beta -cell-specific enhancer in the human PDX-1 gene is regulated by hepatocyte nuclear factor 3beta (HNF-3beta), HNF1 alpha, and SPs transcription factors. Journal of Biological Chemistry 276 17533-17540. (https://doi.org/10.1074/jbc.M009088200)

Bensellam M, Van Lommel L, Overbergh L, Schuit FC \& Jonas JC 2009 Cluster analysis of rat pancreatic islet gene mRNA levels after culture in low-, intermediate- and high-glucose concentrations. Diabetologia 52 463-476. (https://doi.org/10.1007/s00125-008-1245-z)

Bensellam M, Duvillie B, Rybachuk G, Laybutt DR, Magnan C, Guiot Y, Pouyssegur J \& Jonas JC $2012 a$ Glucose-induced O(2) consumption activates hypoxia inducible factors 1 and 2 in rat insulin-secreting pancreatic beta-cells. PLOS ONE 7 e29807. (https://doi.org/10.1371/ journal.pone.0029807)

Bensellam M, Laybutt DR \& Jonas JC 2012b The molecular mechanisms of pancreatic beta-cell glucotoxicity: recent findings and future research directions. Molecular and Cellular Endocrinology 364 1-27. (https://doi.org/10.1016/j.mce.2012.08.003)

Bensellam M, Montgomery MK, Luzuriaga J, Chan JY \& Laybutt DR 2015 Inhibitor of differentiation proteins protect against oxidative stress by regulating the antioxidant-mitochondrial response in mouse beta cells. Diabetologia 58 758-770. (https://doi.org/10.1007/s00125-0153503-1)

Bensellam M, Maxwell EL, Chan JY, Luzuriaga J, West PK, Jonas JC, Gunton JE \& Laybutt DR 2016 Hypoxia reduces ER-to-Golgi protein trafficking and increases cell death by inhibiting the adaptive unfolded protein response in mouse beta cells. Diabetologia 59 1492-1502. (https://doi.org/10.1007/s00125-016-3947-y)

Blum B, Roose AN, Barrandon O, Maehr R, Arvanites AC, Davidow LS, Davis JC, Peterson QP, Rubin LL \& Melton DA 2014 Reversal of beta cell de-differentiation by a small molecule inhibitor of the TGFbeta pathway. eLife 3 e02809. (https://doi.org/10.7554/eLife.05105)

Brereton MF, Iberl M, Shimomura K, Zhang Q, Adriaenssens AE, Proks P, Spiliotis, II, Dace W, Mattis KK, Ramracheya R, et al. 2014 Reversible changes in pancreatic islet structure and function produced by elevated blood glucose. Nature Communications 5 4639. (https://doi. org/10.1038/ncomms5639)

Briaud I, Rouault C, Reach G \& Poitout V 1999 Long-term exposure of isolated rat islets of Langerhans to supraphysiologic glucose concentrations decreases insulin mRNA levels. Metabolism 48 319-323. (https://doi.org/10.1016/S0026-0495(99)90079-3)

Brun T, Roche E, Assimacopoulos-Jeannet F, Corkey BE, Kim KH \& Prentki M 1996 Evidence for an anaplerotic/malonyl-CoA pathway in pancreatic beta-cell nutrient signaling. Diabetes 45 190-198. (https://doi.org/10.2337/diab.45.2.190)

Bugliani M, Liechti R, Cheon H, Suleiman M, Marselli L, Kirkpatrick C, Filipponi F, Boggi U, Xenarios I, Syed F, et al. 2013 Microarray analysis of isolated human islet transcriptome in type 2 diabetes and the role of the ubiquitin-proteasome system in pancreatic beta cell dysfunction. Molecular and Cellular Endocrinology 367 1-10. (https://doi.org/10.1016/j.mce.2012.12.001)

Busch RS \& Kane MP 2017 Combination SGLT2 inhibitor and GLP-1 receptor agonist therapy: a complementary approach to the treatment of type 2 diabetes. Postgraduate Medical 129 686-697. (https://doi.org/ 10.1080/00325481.2017.1342509)

Butler AE, Janson J, Bonner-Weir S, Ritzel R, Rizza RA \& Butler PC $2003 \beta$-cell deficit and increased $\beta$-cell apoptosis in humans with type 2 diabetes. Diabetes 52 102-110. (https://doi.org/10.2337/ diabetes.52.1.102)

Campbell JE \& Drucker DJ 2013 Pharmacology, physiology, and mechanisms of incretin hormone action. Cell Metabolism 17 819-837. (https://doi.org/10.1016/j.cmet.2013.04.008)

Cha JY, Kim H, Kim KS, Hur MW \& Ahn Y 2000 Identification of transacting factors responsible for the tissue-specific expression 
of human glucose transporter type 2 isoform gene. Cooperative role of hepatocyte nuclear factors 1alpha and 3beta. Journal of Biological Chemistry 275 18358-18365. (https://doi.org/10.1074/jbc. M909536199)

Chabosseau P \& Rutter GA 2016 Zinc and diabetes. Archives of Biochemistry and Biophysics 611 79-85. (https://doi.org/10.1016/j. abb.2016.05.022)

Chan JY, Cooney GJ, Biden TJ \& Laybutt DR 2011 Differential regulation of adaptive and apoptotic unfolded protein response signalling by cytokine-induced nitric oxide production in mouse pancreatic beta cells. Diabetologia 54 1766-1776. (https://doi.org/10.1007/s00125011-2139-z)

Chan JY, Luzuriaga J, Bensellam M, Biden TJ \& Laybutt DR 2013 Failure of the adaptive unfolded protein response in islets of obese mice is linked with abnormalities in beta-cell gene expression and progression to diabetes. Diabetes 62 1557-1568. (https://doi. org/10.2337/db12-0701)

Chan JY, Luzuriaga J, Maxwell EL, West PK, Bensellam M \& Laybutt DR 2015 The balance between adaptive and apoptotic unfolded protein responses regulates beta-cell death under ER stress conditions through XBP1, CHOP and JNK. Molecular and Cellular Endocrinology $\mathbf{4 1 3}$ 189-201. (https://doi.org/10.1016/j.mce.2015.06.025)

Chen NG, Tassava TM \& Romsos DR 1993 Threshold for glucosestimulated insulin secretion in pancreatic islets of genetically obese (ob/ob) mice is abnormally low. Journal of Nutrition 123 1567-1574.

Chen L, Yan HX, Chen J, Yang W, Liu Q, Zhai B, Cao HF, Liu SQ, Wu MC \& Wang HY 2007 Negative regulation of c-Myc transcription by pancreas duodenum homeobox-1. Endocrinology 148 2168-2180. (https://doi.org/10.1210/en.2006-1221)

Chen F, Sha M, Wang Y, Wu T, Shan W, Liu J, Zhou W, Zhu Y, Sun Y, Shi Y, et al. 2016 Transcription factor Ets-1 links glucotoxicity to pancreatic beta cell dysfunction through inhibiting PDX-1 expression in rodent models. Diabetologia 59 316-324. (https://doi.org/10.1007/ s00125-015-3805-3)

Cinti F, Bouchi R, Kim-Muller JY, Ohmura Y, Sandoval PR, Masini M, Marselli L, Suleiman M, Ratner LE, Marchetti P, et al. 2016 Evidence of beta-cell dedifferentiation in human type 2 diabetes. Journal of Clinical Endocrinology and Metabolism 101 1044-1054. (https://doi. org/10.1210/jc.2015-2860)

Cockburn BN, Ostrega DM, Sturis J, Kubstrup C, Polonsky KS \& Bell GI 1997 Changes in pancreatic islet glucokinase and hexokinase activities with increasing age, obesity, and the onset of diabetes. Diabetes 46 1434-1439. (https://doi.org/10.2337/diab.46.9.1434)

De Vos A, Heimberg H, Quartier E, Huypens P, Bouwens L, Pipeleers D \& Schuit F 1995 Human and rat beta cells differ in glucose transporter but not in glucokinase gene expression. Journal of Clinical Investigation 96 2489-2495.

Del Vecchio CA, Feng Y, Sokol ES, Tillman EJ, Sanduja S, Reinhardt F \& Gupta PB 2014 De-differentiation confers multidrug resistance via noncanonical PERK-Nrf2 signaling. PLoS Biology 12 e1001945. (https://doi.org/10.1371/journal.pbio.1001945)

Delepine M, Nicolino M, Barrett T, Golamaully M, Lathrop GM \& Julier C 2000 EIF2AK3, encoding translation initiation factor 2-alpha kinase 3 , is mutated in patients with Wolcott-Rallison syndrome. Nature Genetics 25 406-409. (https://doi.org/10.1038/78085)

DelGuerra S, Lupi R, Marselli L, Masini M, Bugliani M, Sbrana S, Torri S, Pollera M, Boggi U, Mosca F, et al. 2005 Functional and molecular defects of pancreatic islets in human type 2 diabetes. Diabetes $\mathbf{5 4}$ 727-735. (https://doi.org/10.2337/diabetes.54.3.727)

DelGuerra S, Grupillo M, Masini M, Lupi R, Bugliani M, Torri S, Boggi U, Del CM, Vistoli F, Mosca F, et al. 2007 Gliclazide protects human islet beta-cells from apoptosis induced by intermittent high glucose. Diabetes/Metabolism Research and Reviews 23 234-238. (https://doi. org/10.1002/dmrr.680)

Deng S, Vatamaniuk M, Huang X, Doliba N, Lian MM, Frank A, Velidedeoglu E, Desai NM, Koeberlein B, Wolf B, et al. 2004 Structural and functional abnormalities in the islets isolated from type 2 diabetic subjects. Diabetes 53 624-632. (https://doi.org/10.2337/ diabetes.53.3.624)

Detimary P, Jonas JC \& Henquin JC 1996 Stable and diffusible pools of nucleotides in pancreatic islet cells. Endocrinology 137 4671-4676. (https://doi.org/10.1210/endo.137.11.8895332)

Detimary P, Gilon P \& Henquin JC 1998 Interplay between cytoplasmic $\mathrm{Ca}^{2+}$ and the ATP/ADP ratio: a feedback control mechanism in mouse pancreatic islets. Biochemical Journal 333 269-274. (https://doi. org/10.1042/bj3330269)

Dhawan S, Tschen SI, Zeng C, Guo T, Hebrok M, Matveyenko A \& Bhushan A 2015 DNA methylation directs functional maturation of pancreatic beta cells. Journal of Clinical Investigation 125 2851-2860. (https://doi.org/10.1172/JCI79956)

Do OH, Low JT, Gaisano HY \& Thorn P 2014 The secretory deficit in islets from $\mathrm{db} / \mathrm{db}$ mice is mainly due to a loss of responding beta cells. Diabetologia 57 1400-1409. (https://doi.org/10.1007/s00125-0143226-8)

Donath MY \& Shoelson SE 2011 Type 2 diabetes as an inflammatory disease. Nature Reviews Immunology 11 98-107. (https://doi. org/10.1038/nri2925)

Donath MY, Gross DJ, Cerasi E \& Kaiser N 1999 Hyperglycemiainduced $\beta$-cell apoptosis in pancreatic islets of Psammomys obesus during development of diabetes. Diabetes 48 738-744. (https://doi. org/10.2337/diabetes.48.4.738)

Dowling P, O'Driscoll L, O'Sullivan F, Dowd A, Henry M, Jeppesen PB, Meleady P \& Clynes M 2006 Proteomic screening of glucoseresponsive and glucose non-responsive MIN-6 beta cells reveals differential expression of proteins involved in protein folding, secretion and oxidative stress. Proteomics 6 6578-6587. (https://doi. org/10.1002/pmic.200600298)

Duan Q, Chen C, Yang L, Li N, Gong W, Li S \& Wang DW 2015 MicroRNA regulation of unfolded protein response transcription factor XBP1 in the progression of cardiac hypertrophy and heart failure in vivo. Journal of Translational Medicine 13 363. (https://doi. org/10.1186/s12967-015-0725-4)

Duan JJ, Cai J, Guo YF, Bian XW \& Yu SC 2016 ALDH1A3, a metabolic target for cancer diagnosis and therapy. International Journal of Cancer 139 965-975. (https://doi.org/10.1002/ijc.30091)

Dubois M, Vacher P, Roger B, Huyghe D, Vandewalle B, Kerr-Conte J, Pattou F, Moustaid-Moussa N \& Lang J 2007 Glucotoxicity inhibits late steps of insulin exocytosis. Endocrinology 148 1605-1614. (https:// doi.org/10.1210/en.2006-1022)

Duchen MR, Smith PA \& Ashcroft FM 1993 Substrate-dependent changes in mitochondrial function, intracellular free calcium concentration and membrane channels in pancreatic beta-cells. Biochemical Journal 294 35-42. (https://doi.org/10.1042/bj2940035)

Ediger BN, Lim HW, Juliana C, Groff DN, Williams LT, Dominguez G, Liu JH, Taylor BL, Walp ER, Kameswaran V, et al. 2017 LIM domainbinding 1 maintains the terminally differentiated state of pancreatic beta cells. Journal of Clinical Investigation 127 215-229. (https://doi. org/10.1172/JCI88016)

Efanova IB, Zaitsev SV, Zhivotovsky B, Kohler M, Efendic S, Orrenius S \& Berggren PO 1998 Glucose and tolbutamide induce apoptosis in pancreatic beta-cells. A process dependent on intracellular $\mathrm{Ca} 2+$ concentration. Journal of Biological Chemistry 273 33501-33507. (https://doi.org/10.1074/jbc.273.50.33501)

El Ouaamari A, Baroukh N, Martens GA, Lebrun P, Pipeleers D \& van Obberghen E 2008 miR-375 targets 3'-phosphoinositide-dependent protein kinase- 1 and regulates glucose-induced biological responses in pancreatic beta-cells. Diabetes 57 2708-2717. (https://doi. org/10.2337/db07-1614)

Elouil H, Cardozo AK, Eizirik DL, Henquin JC \& Jonas JC 2005 High glucose and hydrogen peroxide increase c-Myc and haeme-oxygenase 1 mRNA levels in rat pancreatic islets without activating NFkappaB. Diabetologia 48 496-505. (https://doi.org/10.1007/s00125-004-1664-4) 
Elouil H, Bensellam M, Guiot Y, Vander Mierde D, Pascal SM, Schuit FC \& Jonas JC 2007 Acute nutrient regulation of the unfolded protein response and integrated stress response in cultured rat pancreatic islets. Diabetologia 50 1442-1452. (https://doi.org/10.1007/s00125-007-0674-4)

Engin F, Yermalovich A, Nguyen T, Hummasti S, Fu W, Eizirik DL, Mathis D \& Hotamisligil GS 2013 Restoration of the unfolded protein response in pancreatic beta cells protects mice against type 1 diabetes. Science Translational Medicine 5 211ra156. (https://doi.org/10.1126/ scitranslmed.3006534)

Engin F, Nguyen T, Yermalovich A \& Hotamisligil GS 2014 Aberrant islet unfolded protein response in type 2 diabetes. Scientific Reports 44054 (https://doi.org/10.1038/srep04054)

Esguerra JL, Bolmeson C, Cilio CM \& Eliasson L 2011 Differential glucoseregulation of microRNAs in pancreatic islets of non-obese type 2 diabetes model Goto-Kakizaki rat. PLoS ONE 6 e18613. (https://doi. org/10.1371/journal.pone.0018613)

Eto K, Tsubamoto Y, Terauchi Y, Sugiyama T, Kishimoto T, Takahashi N, Yamauchi N, Kubota N, Murayama S, Aizawa T, et al. 1999 Role of NADH shuttle system in glucose-induced activation of mitochondrial metabolism and insulin secretion. Science 283 981-985. (https://doi. org/10.1126/science.283.5404.981)

Fang N, Zhang W, Xu S, Lin H, Wang Z, Liu H, Fang Q, Li C, Peng L \& Lou J 2014 TRIB3 alters endoplasmic reticulum stress-induced betacell apoptosis via the NF-kappaB pathway. Metabolism 63 822-830. (https://doi.org/10.1016/j.metabol.2014.03.003)

Farfari S, Schulz V, Corkey B \& Prentki M 2000 Glucose-regulated anaplerosis and cataplerosis in pancreatic beta-cells: possible implication of a pyruvate/citrate shuttle in insulin secretion. Diabetes 49 718-726. (https://doi.org/10.2337/diabetes.49.5.718)

Ferdaoussi M, Dai X, Jensen MV, Wang R, Peterson BS, Huang C, Ilkayeva O, Smith N, Miller N, Hajmrle C, et al. 2015 Isocitrate-toSENP1 signaling amplifies insulin secretion and rescues dysfunctional beta cells. Journal of Clinical Investigation 125 3847-3860. (https://doi. org/10.1172/JCI82498)

Ferrer J, Benito C \& Gomis R 1995 Pancreatic islet GLUT2 glucose transporter mRNA and protein expression in humans with and without NIDDM. Diabetes 44 1369-1374. (https://doi.org/10.2337/ diab.44.12.1369)

Finegood DT, McArthur MD, Kojwang D, Thomas MJ, Topp BG, Leonard T \& Buckingham RE 2001 Beta-cell mass dynamics in Zucker diabetic fatty rats. Rosiglitazone prevents the rise in net cell death. Diabetes 50 1021-1029. (https://doi.org/10.2337/diabetes.50.5.1021)

Flamez D, Berger V, Kruhoffer M, Orntoft T, Pipeleers D \& Schuit FC 2002 Critical role for cataplerosis via citrate in glucose-regulated insulin release. Diabetes 51 2018-2024. (https://doi.org/10.2337/ diabetes.51.7.2018)

Fred RG, Bang-Berthelsen CH, Mandrup-Poulsen T, Grunnet LG \& Welsh N 2010 High glucose suppresses human islet insulin biosynthesis by inducing miR-133a leading to decreased polypyrimidine tract binding protein-expression. PLOS ONE 5 e10843. (https://doi.org/10.1371/journal.pone.0010843)

Fu S, Yalcin A, Lee GY, Li P, Fan J, Arruda AP, Pers BM, Yilmaz M, Eguchi K \& Hotamisligil GS 2015 Phenotypic assays identify azoramide as a small-molecule modulator of the unfolded protein response with antidiabetic activity. Science Translational Medicine 7 292ra298.

Gaisano HY, Ostenson CG, Sheu L, Wheeler MB \& Efendic S 2002 Abnormal expression of pancreatic islet exocytotic soluble $\mathrm{N}$-ethylmaleimide-sensitive factor attachment protein receptors in Goto-Kakizaki rats is partially restored by phlorizin treatment and accentuated by high glucose treatment. Endocrinology 143 4218-4226. (https://doi.org/10.1210/en.2002-220237)

Gao T, McKenna B, Li C, Reichert M, Nguyen J, Singh T, Yang C, Pannikar A, Doliba N, Zhang T, et al. 2014 Pdx1 maintains beta cell identity and function by repressing an alpha cell program. Cell Metabolism 19 259-271. (https://doi.org/10.1016/j.cmet.2013.12.002)
Gautam D, Han SJ, Duttaroy A, Mears D, Hamdan FF, Li JH, Cui Y, Jeon J \& Wess J 2007 Role of the M3 muscarinic acetylcholine receptor in beta-cell function and glucose homeostasis. Diabetes, Obesity and Metabolism 9 (Supplement 2) 158-169. (https://doi.org/10.1111/ j.1463-1326.2007.00781.x)

Ghanaat-Pour H, Huang Z, Lehtihet M \& Sjoholm A 2007 Global expression profiling of glucose-regulated genes in pancreatic islets of spontaneously diabetic Goto-Kakizaki rats. Journal of Molecular Endocrinology 39 135-150. (https://doi.org/10.1677/JME-07-0002)

Gleason CE, Gonzalez M, Harmon JS \& Robertson RP 2000 Determinants of glucose toxicity and its reversibility in the pancreatic islet $\beta$-cell line, HIT-T15. American Journal of Physiology: Endocrinology and Metabolism 279 E997-E1002.

Gomez E, Powell ML, Bevington A \& Herbert TP 2008 A decrease in cellular energy status stimulates PERK-dependent eIF2alpha phosphorylation and regulates protein synthesis in pancreatic betacells. Biochemical Journal 410 485-493. (https://doi.org/10.1042/ BJ20071367)

Gozzelino R \& Soares MP 2014 Coupling heme and iron metabolism via ferritin H chain. Antioxidants and Redox Signaling 20 1754-1769. (https://doi.org/10.1089/ars.2013.5666)

Grafi G \& Barak S 2015 Stress induces cell dedifferentiation in plants. Biochimica et Biophysica Acta 1849 378-384. (https://doi. org/10.1016/j.bbagrm.2014.07.015)

Gravena C, Mathias PC \& Ashcroft SJ 2002 Acute effects of fatty acids on insulin secretion from rat and human islets of Langerhans. Journal of Endocrinology 173 73-80. (https://doi.org/10.1677/joe.0.1730073)

Grill V, Lake W \& Freinkel N 1981 Generalized diminution in the response to nutrients as insulin-releasing agents during the early neonatal period in the rat. Diabetes 30 56-63. (https://doi. org/10.2337/diab.30.1.56)

Grill V, Radtke M, Qvigstad E, Kollind M \& Bjorklund A 2009 Beneficial effects of K-ATP channel openers in diabetes: an update on mechanisms and clinical experiences. Diabetes, Obesity and Metabolism 11 (Supplement 4) 143-148. (https://doi.org/10.1111/j.14631326.2009.01119.x)

Gunton JE, Kulkarni RN, Yim S, Okada T, Hawthorne WJ, Tseng YH, Roberson RS, Ricordi C, O'Connell PJ, Gonzalez FJ, et al. 2005 Loss of ARNT/HIF1beta mediates altered gene expression and pancreatic-islet dysfunction in human type 2 diabetes. Cell 122 337-349. (https://doi. org/10.1016/j.cell.2005.05.027)

Guo S, Dai C, Guo M, Taylor B, Harmon JS, Sander M, Robertson RP, Powers AC \& Stein R 2013 Inactivation of specific beta cell transcription factors in type 2 diabetes. Journal of Clinical Investigation 123 3305-3316. (https://doi.org/10.1172/JCI65390)

Gutierrez GD, Bender AS, Cirulli V, Mastracci TL, Kelly SM, Tsirigos A, Kaestner KH \& Sussel L 2017 Pancreatic beta cell identity requires continual repression of non-beta cell programs. Journal of Clinical Investigation 127 244-259. (https://doi.org/10.1172/JCI88017)

Hall E, Dayeh T, Kirkpatrick CL, Wollheim CB, Dekker Nitert M \& Ling C 2013 DNA methylation of the glucagon-like peptide 1 receptor (GLP1R) in human pancreatic islets. BMC Medical Genetics 1476. (https://doi.org/10.1186/1471-2350-14-76)

Han D, Lerner AG, Vande Walle L, Upton JP, Xu W, Hagen A, Backes BJ, Oakes SA \& Papa FR 2009 IRE1alpha kinase activation modes contro alternate endoribonuclease outputs to determine divergent cell fates. Cell 138 562-575. (https://doi.org/10.1016/j.cell.2009.07.017)

Han J, Song B, Kim J, Kodali VK, Pottekat A, Wang M, Hassler J, Wang S, Pennathur S, Back SH, et al. 2015 Antioxidants complement the requirement for protein chaperone function to maintain beta-cell function and glucose homeostasis. Diabetes 64 2892-2904. (https://doi.org/10.2337/db14-1357)

Harding HP, Zeng H, Zhang Y, Jungries R, Chung P, Plesken H, Sabatini DD \& Ron D 2001 Diabetes mellitus and exocrine pancreatic dysfunction in perk-/- mice reveals a role for translational control 
in secretory cell survival. Molecular Cell 7 1153-1163. (https://doi. org/10.1016/S1097-2765(01)00264-7)

Harmon JS, Tanaka Y, Olson LK \& Robertson RP 1998 Reconstitution of glucotoxic HIT-T15 cells with somatostatin transcription factor-1 partially restores insulin promoter activity. Diabetes $\mathbf{4 7} 900-904$. (https://doi.org/10.2337/diabetes.47.6.900)

Harmon JS, Gleason CE, Tanaka Y, Poitout V \& Robertson RP 2001 Antecedent hyperglycemia, not hyperlipidemia, is associated with increased islet triacylglycerol content and decreased insulin gene mRNA level in Zucker diabetic fatty rats. Diabetes 50 2481-2486. (https://doi.org/10.2337/diabetes.50.11.2481)

Harmon JS, Stein R \& Robertson RP 2005 Oxidative stress-mediated, post-translational loss of MafA protein as a contributing mechanism to loss of insulin gene expression in glucotoxic beta cells. Journal of Biological Chemistry 280 11107-11113. (https://doi.org/10.1074/jbc. M410345200)

Harmon JS, Bogdani M, Parazzoli SD, Mak SS, Oseid EA, Berghmans M, Leboeuf RC \& Robertson RP 2009 beta-Cell-specific overexpression of glutathione peroxidase preserves intranuclear MafA and reverses diabetes in db/db mice. Endocrinology 150 4855-4862. (https://doi. org/10.1210/en.2009-0708)

Hasan NM, Longacre MJ, Seed Ahmed M, Kendrick MA, Gu H, Ostenson CG, Fukao T \& MacDonald MJ 2010 Lower succinyl-CoA:3ketoacid-CoA transferase (SCOT) and ATP citrate lyase in pancreatic islets of a rat model of type 2 diabetes: knockdown of SCOT inhibits insulin release in rat insulinoma cells. Archives of Biochemistry and Biophysics 499 62-68. (https://doi.org/10.1016/j.abb.2010.05.007)

Hassler JR, Scheuner DL, Wang S, Han J, Kodali VK, Li P, Nguyen J, George JS, Davis C, Wu SP, et al. 2015 The IRE1alpha/XBP1s pathway is essential for the glucose response and protection of beta cells. PLoS Biology 13 e1002277. (https://doi.org/10.1371/journal.pbio.1002277)

Hattersley AT \& Patel KA 2017 Precision diabetes: learning from monogenic diabetes. Diabetologia 60 769-777. (https://doi. org/10.1007/s00125-017-4226-2)

Hauge-Evans AC, Reers C, Kerby A, Franklin Z, Amisten S, King AJ, Hassan Z, Vilches-Flores A, Tippu Z, Persaud SJ, et al. 2014 Effect of hyperglycaemia on muscarinic M3 receptor expression and secretory sensitivity to cholinergic receptor activation in islets. Diabetes, Obesity and Metabolism 16 947-956. (https://doi.org/10.1111/dom.12301)

Hellman B \& Taljedal IB 1967 Quantitative studies on isolated pancreatic islets of mammals. Activity and heterogeneity of lactate dehydrogenase in obese-hyperglycemic mice. Endocrinology $\mathbf{8 1}$ 125-131. (https://doi.org/10.1210/endo-81-1-125)

Henquin JC 2011 The dual control of insulin secretion by glucose involves triggering and amplifying pathways in beta-cells. Diabetes Research and Clinical Practice 93 (Supplement 1) S27-S31. (https://doi. org/10.1016/S0168-8227(11)70010-9)

Herbert TP \& Laybutt DR 2016 A reevaluation of the role of the unfolded protein response in islet dysfunction: maladaptation or a failure to adapt? Diabetes 65 1472-1480. (https://doi.org/10.2337/ db15-1633)

Hollien J \& Weissman JS 2006 Decay of endoplasmic reticulum-localized mRNAs during the unfolded protein response. Science 313 104-107. (https://doi.org/10.1126/science.1129631)

Hollien J, Lin JH, Li H, Stevens N, Walter P \& Weissman JS 2009 Regulated Ire1-dependent decay of messenger RNAs in mammalian cells. Journal of Cell Biology 186 323-331. (https://doi.org/10.1083/ jcb.200903014)

Homo-Delarche F, Calderari S, Irminger JC, Gangnerau MN, Coulaud J, Rickenbach K, Dolz M, Halban P, Portha B \& Serradas P 2006 Islet inflammation and fibrosis in a spontaneous model of type 2 diabetes, the GK rat. Diabetes 55 1625-1633. (https://doi.org/10.2337/db051526)

Hosokawa H, Hosokawa YA \& Leahy JL 1995 Upregulated hexokinase activity in isolated islets from diabetic $90 \%$ pancreatectomized rats. Diabetes 44 1328-1333. (https://doi.org/10.2337/diab.44.11.1328)
Hou N, Torii S, Saito N, Hosaka M \& Takeuchi T 2008a Reactive oxygen species-mediated pancreatic beta-cell death is regulated by interactions between stress-activated protein kinases, p38 and c-Jun N-terminal kinase, and mitogen-activated protein kinase phosphatases. Endocrinology 149 1654-1665. (https://doi.org/10.1210/ en.2007-0988)

Hou ZQ, Li HL, Gao L, Pan L, Zhao JJ \& Li GW $2008 b$ Involvement of chronic stresses in rat islet and INS-1 cell glucotoxicity induced by intermittent high glucose. Molecular and Cellular Endocrinology 291 71-78. (https://doi.org/10.1016/j.mce.2008.03.004)

Huang Q, Bu S, Yu Y, Guo Z, Ghatnekar G, Bu M, Yang L, Lu B, Feng Z, Liu S, et al. 2007 Diazoxide prevents diabetes through inhibiting pancreatic beta-cells from apoptosis via Bcl-2/Bax rate and p38-beta mitogen-activated protein kinase. Endocrinology 148 81-91. (https://doi.org/10.1210/en.2006-0738)

Ishida E, Kim-Muller JY \& Accili D 2017 Pair feeding, but not insulin, phloridzin, or rosiglitazone treatment, curtails markers of beta-cell dedifferentiation in db/db mice. Diabetes 66 2092-2101. (https://doi. org/10.2337/db16-1213)

Ishihara H, Asano T, Tsukuda K, Katagiri H, Inukai K, Anai M, Kikuchi M, Yazaki Y, Miyazaki J \& Oka Y 1994 Overexpression of hexokinase I but not GLUT1 glucose transporter alters concentration dependence of glucose-stimulated insulin secretion in pancreatic beta-cell line MIN6. Journal of Biological Chemistry 269 3081-3087.

Ishihara H, Wang H, Drewes LR \& Wollheim CB 1999 Overexpression of monocarboxylate transporter and lactate dehydrogenase alters insulin secretory responses to pyruvate and lactate in beta cells. Journal of Clinical Investigation 104 1621-1629. (https://doi.org/10.1172/ JCI7515)

Itoh Y, Kawamata Y, Harada M, Kobayashi M, Fujii R, Fukusumi S, Ogi K, Hosoya M, Tanaka Y, Uejima H, et al. 2003 Free fatty acids regulate insulin secretion from pancreatic beta cells through GPR40. Nature 422 173-176. (https://doi.org/10.1038/nature01478)

Ivarsson R, Quintens R, Dejonghe S, Tsukamoto K, in 't Veld P, Renstrom E \& Schuit FC 2005 Redox control of exocytosis: regulatory role of NADPH, thioredoxin, and glutaredoxin. Diabetes $\mathbf{5 4}$ 2132-2142. (https://doi.org/10.2337/diabetes.54.7.2132)

Iwashima Y, Kondoh-Abiko A, Seino S, Takeda J, Eto M, Polonsky KS \& Makino I 1994 Reduced levels of messenger ribonucleic acid for calcium channel, glucose transporter-2, and glucokinase are associated with alterations in insulin secretion in fasted rats. Endocrinology 135 1010-1017. (https://doi.org/10.1210/ endo.135.3.8070343)

Iwawaki T, Akai R \& Kohno K 2010 IRE1alpha disruption causes histological abnormality of exocrine tissues, increase of blood glucose level, and decrease of serum immunoglobulin level. PLOS ONE 5 e13052. (https://doi.org/10.1371/journal.pone.0013052)

Jacovetti C, Matkovich SJ, Rodriguez-Trejo A, Guay C \& Regazzi R 2015 Postnatal beta-cell maturation is associated with islet-specific microRNA changes induced by nutrient shifts at weaning. Nature Communications 6 8084. (https://doi.org/10.1038/ncomms9084)

Jermendy A, Toschi E, Aye T, Koh A, Aguayo-Mazzucato C, Sharma A, Weir GC, Sgroi D \& Bonner-Weir S 2011 Rat neonatal beta cells lack the specialised metabolic phenotype of mature beta cells. Diabetologia 54 594-604. (https://doi.org/10.1007/s00125-010-2036-x)

Jitrapakdee S, Wutthisathapornchai A, Wallace JC \& MacDonald MJ 2010 Regulation of insulin secretion: role of mitochondrial signalling. Diabetologia 53 1019-1032. (https://doi.org/10.1007/s00125-010 1685-0)

Jonas JC, Sharma A, Hasenkamp W, Ilkova H, Patane G, Laybutt R, Bonner-Weir S \& Weir GC 1999 Chronic hyperglycemia triggers loss of pancreatic beta cell differentiation in an animal model of diabetes. Journal of Biological Chemistry 274 14112-14121. (https://doi. org/10.1074/jbc.274.20.14112

Jonas JC, Laybutt DR, Steil GM, Trivedi N, Pertusa JG, Van de Casteele M, Weir GC \& Henquin JC 2001 High glucose stimulates early response 
gene c-Myc expression in rat pancreatic beta cells. Journal of Biological Chemistry 276 35375-35381. (https://doi.org/10.1074/jbc. M105020200)

Jonas JC, Guiot Y, Rahier J \& Henquin JC 2003 Haeme-oxygenase 1 expression in rat pancreatic $\beta$-cells is stimulated by supraphysiological glucose concentrations and by cyclic AMP. Diabetologia 46 1234-1244. (https://doi.org/10.1007/s00125-003-1174-9)

Jonas JC, Bensellam M, Duprez J, Elouil H, Guiot Y \& Pascal SM 2009 Glucose regulation of islet stress responses and beta-cell failure in type 2 diabetes. Diabetes, Obesity and Metabolism 11 (Supplement 4) 65-81. (https://doi.org/10.1111/j.1463-1326.2009.01112.x)

Julier C \& Nicolino M 2010 Wolcott-Rallison syndrome. Orphanet Journal of Rare Diseases 5 29. (https://doi.org/10.1186/1750-1172-5-29)

Jurgens CA, Toukatly MN, Fligner CL, Udayasankar J, Subramanian SL, Zraika S, Aston-Mourney K, Carr DB, Westermark P, Westermark GT, et al. 2011 beta-cell loss and beta-cell apoptosis in human type 2 diabetes are related to islet amyloid deposition. American Journal of Pathology 178 2632-2640. (https://doi.org/10.1016/j. ajpath.2011.02.036)

Kaneto H, Xu G, Song KH, Suzuma K, Bonner-Weir S, Sharma A \& Weir GC 2001 Activation of the hexosamine pathway leads to deterioration of pancreatic beta-cell function through the induction of oxidative stress. Journal of Biological Chemistry 276 31099-31104. (https://doi.org/10.1074/jbc.M104115200)

Kaneto H, Sharma A, Suzuma K, Laybutt DR, Xu G, Bonner-Weir S \& Weir GC 2002a Induction of c-Myc expression suppresses insulin gene transcription by inhibiting NeuroD/BETA2-mediated transcriptional activation. Journal of Biological Chemistry 277 12998-13006. (https://doi.org/10.1074/jbc.M111148200)

Kaneto H, Xu G, Fujii N, Kim S, Bonner-Weir S \& Weir GC 2002b Involvement of c-Jun N-terminal kinase in oxidative stress-mediated suppression of insulin gene expression. Journal of Biological Chemistry 277 30010-30018. (https://doi.org/10.1074/jbc.M202066200)

Kaneto H, Obata A, Kimura T, Shimoda M, Okauchi S, Shimo N, Matsuoka TA \& Kaku K 2017 Beneficial effects of sodium-glucose cotransporter 2 inhibitors for preservation of pancreatic beta-cell function and reduction of insulin resistance. Journal of Diabetes 9 219-225. (https://doi.org/10.1111/1753-0407.12494)

Kassis N, Bernard C, Pusterla A, Casteilla L, Penicaud L, Richard D, Ricquier D \& Ktorza A 2000 Correlation between pancreatic islet uncoupling protein-2 (UCP2) mRNA concentration and insulin status in rats. International Journal of Experimental Diabetes Research $\mathbf{1}$ 185-193. (https://doi.org/10.1155/EDR.2000.185)

Kawamori D, Kajimoto Y, Kaneto H, Umayahara Y, Fujitani Y, Miyatsuka T, Watada H, Leibiger IB, Yamasaki Y \& Hori M 2003 Oxidative stress induces nucleo-cytoplasmic translocation of pancreatic transcription factor PDX-1 through activation of c-Jun NH(2)-terminal kinase. Diabetes 52 2896-2904. (https://doi. org/10.2337/diabetes.52.12.2896)

Kawamori D, Kaneto H, Nakatani Y, Matsuoka TA, Matsuhisa M, Hori M \& Yamasaki Y 2006 The forkhead transcription factor Foxo1 bridges the JNK pathway and the transcription factor PDX-1 through its intracellular translocation. Journal of Biological Chemistry 281 1091-1098. (https://doi.org/10.1074/jbc. M508510200)

Keller G 2005 Embryonic stem cell differentiation: emergence of a new era in biology and medicine. Genes and Development 19 1129-1155. (https://doi.org/10.1101/gad.1303605)

Khaldi MZ, Guiot Y, Gilon P, Henquin JC \& Jonas JC 2004 Increased glucose sensitivity of both triggering and amplifying pathways of insulin secretion in rat islets cultured for one week in high glucose. American Journal of Physiology: Endocrinology and Metabolism 287 E207-E217. (https://doi.org/10.1152/ajpendo.00426.2003)

Khan A, Ling ZC \& Landau BR 1996 Quantifying the carboxylation of pyruvate in pancreatic islets. Journal of Biological Chemistry 271 2539-2542. (https://doi.org/10.1074/jbc.271.5.2539)
Kim-Muller JY, Zhao S, Srivastava S, Mugabo Y, Noh HL, Kim YR, Madiraju SR, Ferrante AW, Skolnik EY, Prentki M, et al. 2014 Metabolic inflexibility impairs insulin secretion and results in MODY-like diabetes in triple FoxO-deficient mice. Cell Metabolism 20 593-602. (https://doi.org/10.1016/j.cmet.2014.08.012)

Kim-Muller JY, Fan J, Kim YJ, Lee SA, Ishida E, Blaner WS \& Accili D 2016 Aldehyde dehydrogenase $1 \mathrm{a} 3$ defines a subset of failing pancreatic beta cells in diabetic mice. Nature Communications 712631. (https://doi.org/10.1038/ncomms12631)

Kim JW, Seghers V, Cho JH, Kang Y, Kim S, Ryu Y, Baek K, AguilarBryan L, Lee YD, Bryan J, et al. 2002 Transactivation of the mouse sulfonylurea receptor I gene by BETA2/NeuroD. Molecular Endocrinology 16 1097-1107. (https://doi.org/10.1210/ mend.16.5.0934)

Kim JW, You YH, Jung S, Suh-Kim H, Lee IK, Cho JH \& Yoon KH 2013 miRNA-30a-5p-mediated silencing of Beta2/NeuroD expression is an important initial event of glucotoxicity-induced beta cell dysfunction in rodent models. Diabetologia 56 847-855. (https://doi.org/10.1007/ s00125-012-2812-x)

Kitamura T 2013 The role of FOXO1 in beta-cell failure and type 2 diabetes mellitus. Nature Reviews Endocrinology 9 615-623. (https://doi. org/10.1038/nrendo.2013.157)

Kitamura T, Nakae J, Kitamura Y, Kido Y, Biggs WH 3rd, Wright CV, White MF, Arden KC \& Accili D 2002 The forkhead transcription factor Foxo1 links insulin signaling to Pdx1 regulation of pancreatic beta cell growth. Journal of Clinical Investigation 110 1839-1847. (https://doi.org/10.1172/JCI200216857)

Kitamura YI, Kitamura T, Kruse JP, Raum JC, Stein R, Gu W \& Accili D 2005 FoxO1 protects against pancreatic beta cell failure through NeuroD and MafA induction. Cell Metabolism 2 153-163. (https://doi. org/10.1016/j.cmet.2005.08.004)

Kjorholt C, Akerfeldt MC, Biden TJ \& Laybutt DR 2005 Chronic hyperglycemia, independent of plasma lipid levels, is sufficient for the loss of $\beta$-cell differentiation and secretory function in the $\mathrm{db} /$ $\mathrm{db}$ mouse model of diabetes. Diabetes 54 2755-2763. (https://doi. org/10.2337/diabetes.54.9.2755)

Kluth O, Mirhashemi F, Scherneck S, Kaiser D, Kluge R, Neschen S, Joost HG \& Schurmann A 2011 Dissociation of lipotoxicity and glucotoxicity in a mouse model of obesity associated diabetes: role of forkhead box O1 (FOXO1) in glucose-induced beta cell failure. Diabetologia 54 605-616. (https://doi.org/10.1007/s00125-010-1973-8)

Kooptiwut S, Zraika S, Thorburn AW, Dunlop ME, Darwiche R, Kay TW, Proietto J \& Andrikopoulos S 2002 Comparison of insulin secretory function in two mouse models with different susceptibility to betacell failure. Endocrinology 143 2085-2092. (https://doi.org/10.1210/ endo.143.6.8859)

Koyama M, Wada R, Sakuraba H, Mizukami H \& Yagihashi S 1998 Accelerated loss of islet beta cells in sucrose-fed Goto-Kakizaki rats, a genetic model of non-insulin-dependent diabetes mellitus. American Journal of Pathology 153 537-545. (https://doi.org/10.1016/S00029440(10)65596-4)

Lacraz G, Figeac F, Movassat J, Kassis N, Coulaud J, Galinier A, Leloup C, Bailbe D, Homo-Delarche F \& Portha B 2009 Diabetic beta-cells can achieve self-protection against oxidative stress through an adaptive up-regulation of their antioxidant defenses. PLOS ONE $\mathbf{4}$ e6500. (https://doi.org/10.1371/journal.pone.0006500)

Lacraz G, Figeac F, Movassat J, Kassis N \& Portha B 2010 Diabetic GK/ Par rat beta-cells are spontaneously protected against H2O2-triggered apoptosis. A cAMP-dependent adaptive response. American Journal of Physiology: Endocrinology and Metabolism 298 E17-E27. (https://doi. org/10.1152/ajpendo.90871.2008)

Ladiges WC, Knoblaugh SE, Morton JF, Korth MJ, Sopher BL, Baskin CR, MacAuley A, Goodman AG, LeBoeuf RC \& Katze MG 2005 Pancreatic beta-cell failure and diabetes in mice with a deletion mutation of the endoplasmic reticulum molecular chaperone gene P58IPK. Diabetes 54 1074-1081. (https://doi.org/10.2337/diabetes.54.4.1074) 
Lasorella A, Benezra R \& Iavarone A 2014 The ID proteins: master regulators of cancer stem cells and tumour aggressiveness. Nature Reviews Cancer 14 77-91. (https://doi.org/10.1038/nrc3638)

Latreille M, Hausser J, Stutzer I, Zhang Q, Hastoy B, Gargani S, KerrConte J, Pattou F, Zavolan M, Esguerra JL, et al. 2014 MicroRNA-7a regulates pancreatic beta cell function. Journal of Clinical Investigation 124 2722-2735. (https://doi.org/10.1172/JCI73066)

Lavine RL, Chick WL, Like AA \& Makdisi TW 1971 Glucose tolerance and insulin secretion in neonatal and adult mice. Diabetes 20 134-139. (https://doi.org/10.2337/diab.20.3.134)

Laybutt DR, Kaneto H, Hasenkamp W, Grey S, Jonas JC, Sgroi DC, Groff A, Ferran C, Bonner-Weir S, Sharma A, et al. 2002a Increased expression of antioxidant and antiapoptotic genes in islets that may contribute to beta-cell survival during chronic hyperglycemia. Diabetes 51 413-423. (https://doi.org/10.2337/diabetes.51.2.413)

Laybutt DR, Sharma A, Sgroi DC, Gaudet J, Bonner-Weir S \& Weir GC $2002 b$ Genetic regulation of metabolic pathways in beta-cells disrupted by hyperglycemia. Journal of Biological Chemistry $\mathbf{2 7} 7$ 10912-10921. (https://doi.org/10.1074/jbc.M111751200)

Laybutt DR, Weir GC, Kaneto H, Lebet J, Palmiter RD, Sharma A \& Bonner-Weir S 2002c Overexpression of c-Myc in beta-cells of transgenic mice causes proliferation and apoptosis, downregulation of insulin gene expression, and diabetes. Diabetes 51 1793-1804. (https://doi.org/10.2337/diabetes.51.6.1793)

Laybutt DR, Glandt M, Xu G, Ahn YB, Trivedi N, Bonner-Weir S \& Weir GC 2003 Critical reduction in $\beta$-cell mass results in two distinct outcomes over time. Adaptation with impaired glucose tolerance or decompensated diabetes. Journal of Biological Chemistry $\mathbf{2 7 8}$ 2997-3005. (https://doi.org/10.1074/jbc.M210581200)

Laybutt DR, Hawkins YC, Lock J, Lebet J, Sharma A, Bonner-Weir S \& Weir GC 2007 Influence of diabetes on the loss of beta cell differentiation after islet transplantation in rats. Diabetologia 50 2117-2125. (https://doi.org/10.1007/s00125-007-0749-2)

Leahy JL, Bumbalo LM \& Chen C 1993 Beta-cell hypersensitivity for glucose precedes loss of glucose-induced insulin secretion in 90\% pancreatectomized rats. Diabetologia 36 1238-1244. (https://doi. org/10.1007/BF00400800)

Lee AH, Heidtman K, Hotamisligil GS \& Glimcher LH 2011 Dual and opposing roles of the unfolded protein response regulated by IRE1alpha and XBP1 in proinsulin processing and insulin secretion. PNAS 108 8885-8890. (https://doi.org/10.1073/pnas.1105564108)

Leibowitz G, Ferber S, Apelqvist A, Edlund H, Gross DJ, Cerasi E, Melloul D \& Kaiser N 2001 IPF1/PDX1 deficiency and $\beta$-cell dysfunction in Psammomys obesus, an animal with type 2 diabetes. Diabetes 50 1799-1806. (https://doi.org/10.2337/diabetes.50.8.1799)

Leloup C, Tourrel-Cuzin C, Magnan C, Karaca M, Castel J, Carneiro L, Colombani AL, Ktorza A, Casteilla L \& Penicaud L 2009 Mitochondrial reactive oxygen species are obligatory signals for glucose-induced insulin secretion. Diabetes 58 673-681. (https://doi. org/10.2337/db07-1056)

Lemaire K, Thorrez L \& Schuit F 2016 Disallowed and allowed gene expression: two faces of mature islet beta cells. Annual Review of Nutrition 36 45-71. (https://doi.org/10.1146/annurevnutr-071715-050808)

Lemaire K, Granvik M, Schraenen A, Goyvaerts L, Van Lommel L, GomezRuiz A, in 't Veld P, Gilon P \& Schuit F 2017 How stable is repression of disallowed genes in pancreatic islets in response to metabolic stress? PLOS ONE 12 e0181651. (https://doi.org/10.1371/journal. pone.0181651)

Lenzen S, Drinkgern J \& Tiedge M 1996 Low antioxidant enzyme gene expression in pancreatic islets compared with various other mouse tissues. Free Radical Biology and Medicine 20 463-466. (https://doi. org/10.1016/0891-5849(96)02051-5)

Li X, Chen H \& Epstein PN 2006a Metallothionein and catalase sensitize to diabetes in nonobese diabetic mice: reactive oxygen species may have a protective role in pancreatic beta-cells. Diabetes 55 1592-1604. (https://doi.org/10.2337/db05-1357)

Li X, Zhang L, Meshinchi S, Dias-Leme C, Raffin D, Johnson JD, Treutelaar MK \& Burant CF $2006 b$ Islet microvasculature in islet hyperplasia and failure in a model of type 2 diabetes. Diabetes $\mathbf{5 5}$ 2965-2973. (https://doi.org/10.2337/db06-0733)

Li F, Zhou K, Gao L, Zhang B, Li W, Yan W, Song X, Yu H, Wang S, Yu N, et al. 2016 Radiation induces the generation of cancer stem cells: a novel mechanism for cancer radioresistance. Oncology Letters 12 3059-3065.

Liew CW, Bochenski J, Kawamori D, Hu J, Leech CA, Wanic K, Malecki M, Warram JH, Qi L, Krolewski AS, et al. 2010 The pseudokinase tribbles homolog 3 interacts with ATF4 to negatively regulate insulin exocytosis in human and mouse beta cells. Journal of Clinical Investigation 120 2876-2888. (https://doi.org/10.1172/JCI36849)

Ling Z \& Pipeleers DG 1996 Prolonged exposure of human beta cells to elevated glucose levels results in sustained cellular activation leading to a loss of glucose regulation. Journal of Clinical Investigation $\mathbf{9 8}$ 2805-2812. (https://doi.org/10.1172/JCI119108)

Ling Z, Hannaert JC \& Pipeleers D 1994 Effect of nutrients, hormones and serum on survival of rat islet beta cells in culture. Diabetologia $\mathbf{3 7}$ 15-21. (https://doi.org/10.1007/BF00428772)

Ling Z, Kiekens R, Mahler T, Schuit FC, Pipeleers-Marichal M, Sener A, Kloppel G, Malaisse WJ \& Pipeleers DG 1996 Effects of chronically elevated glucose levels on the functional properties of rat pancreatic beta-cells. Diabetes 45 1774-1782. (https://doi.org/10.2337/ diab.45.12.1774)

Ling ZC, Hong-Lie C, Ostenson CG, Efendic S \& Khan A 2001 Hyperglycemia contributes to impaired insulin response in GK rat islets. Diabetes 50 (Supplement 1) S108-S112. (https://doi. org/10.2337/diabetes.50.2007.S108)

Lipson KL, Ghosh R \& Urano F 2008 The role of IRE1alpha in the degradation of insulin mRNA in pancreatic beta-cells. PLOS ONE $\mathbf{3}$ e1648. (https://doi.org/10.1371/journal.pone.0001648)

Locke JM, da Silva X, Dawe HR, Rutter GA \& Harries LW 2014 Increased expression of miR-187 in human islets from individuals with type 2 diabetes is associated with reduced glucose-stimulated insulin secretion. Diabetologia 57 122-128. (https://doi.org/10.1007/s00125013-3089-4)

Lombardi A, Ulianich L, Treglia AS, Nigro C, Parrillo L, Lofrumento DD, Nicolardi G, Garbi C, Beguinot F, Miele C, et al. 2012 Increased hexosamine biosynthetic pathway flux dedifferentiates INS-1E cells and murine islets by an extracellular signal-regulated kinase (ERK)1/2mediated signal transmission pathway. Diabetologia 55 141-153. (https://doi.org/10.1007/s00125-011-2315-1)

Lovis P, Gattesco S \& Regazzi R 2008 Regulation of the expression of components of the exocytotic machinery of insulin-secreting cells by microRNAs. Biological Chemistry 389 305-312.

Lu M, Seufert J \& Habener JF 1997 Pancreatic beta-cell-specific repression of insulin gene transcription by CCAAT/enhancer-binding protein beta. Inhibitory interactions with basic helix-loop-helix transcription factor E47. Journal of Biological Chemistry 272 28349-28359. (https://doi.org/10.1074/jbc.272.45.28349)

Lu H, Yang Y, Allister EM, Wijesekara N \& Wheeler MB 2008 The identification of potential factors associated with the development of type 2 diabetes: a quantitative proteomics approach. Molecular and Cellular Proteomics 7 1434-1451. (https://doi.org/10.1074/mcp. M700478-MCP200)

Ma Z, Portwood N, Brodin D, Grill V \& Bjorklund A 2007 Effects of diazoxide on gene expression in rat pancreatic islets are largely linked to elevated glucose and potentially serve to enhance $\beta$-cell sensitivity. Diabetes 56 1095-1106. (https://doi.org/10.2337/db06-0322)

MacDonald MJ 1981 High content of mitochondrial glycerol-3-phosphate dehydrogenase in pancreatic islets and its inhibition by diazoxide. Journal of Biological Chemistry 256 8287-8290. 
MacDonald MJ 1982 Evidence for the malate aspartate shuttle in pancreatic islets. Archives of Biochemistry and Biophysics 213 643-649. (https://doi.org/10.1016/0003-9861(82)90594-X)

MacDonald MJ 1993 Glucose enters mitochondrial metabolism via both carboxylation and decarboxylation of pyruvate in pancreatic islets. Metabolism 42 1229-1231. (https://doi.org/10.1016/00260495(93)90118-8)

MacDonald MJ, Tang J \& Polonsky KS 1996 Low mitochondrial glycerol phosphate dehydrogenase and pyruvate carboxylase in pancreatic islets of Zucker diabetic fatty rats. Diabetes 45 1626-1630. (https://doi. org/10.2337/diab.45.11.1626)

MacDonald MJ, Longacre MJ, Langberg EC, Tibell A, Kendrick MA, Fukao T \& Ostenson CG 2009 Decreased levels of metabolic enzymes in pancreatic islets of patients with type 2 diabetes. Diabetologia $\mathbf{5 2}$ 1087-1091. (https://doi.org/10.1007/s00125-009-1319-6)

Mahadevan J, Parazzoli S, Oseid E, Hertzel AV, Bernlohr DA, Vallerie SN, Liu CQ, Lopez M, Harmon JS \& Robertson RP 2013 Ebselen treatment prevents islet apoptosis, maintains intranuclear Pdx-1 and MafA levels, and preserves beta-cell mass and function in ZDF rats. Diabetes 62 3582-3588. (https://doi.org/10.2337/db13-0357)

Malaisse WJ, Sener A, Herchuelz A \& Hutton JC 1979 Insulin release: the fuel hypothesis. Metabolism 28 373-386. (https://doi. org/10.1016/0026-0495(79)90111-2)

Marchetti P, Del GS, Marselli L, Lupi R, Masini M, Pollera M, Bugliani M, Boggi U, Vistoli F, Mosca F, et al. 2004 Pancreatic islets from type 2 diabetic patients have functional defects and increased apoptosis that are ameliorated by metformin. Journal of Clinical Endocrinology and Metabolism 89 5535-5541. (https://doi.org/10.1210/jc.2004-0150)

Marselli L, Thorne J, Dahiya S, Sgroi DC, Sharma A, Bonner-Weir S, Marchetti P \& Weir GC 2010 Gene expression profiles of beta-cell enriched tissue obtained by laser capture microdissection from subjects with type 2 diabetes. PLOS ONE 5 e11499. (https://doi. org/10.1371/journal.pone.0011499)

Marselli L, Suleiman M, Masini M, Campani D, Bugliani M, Syed F, Martino L, Focosi D, Scatena F, Olimpico F, et al. 2014 Are we overestimating the loss of beta cells in type 2 diabetes? Diabetologia 57 362-365. (https://doi.org/10.1007/s00125-013-3098-3)

Marshak S, Leibowitz G, Bertuzzi F, Socci C, Kaiser N, Gross DJ, Cerasi E \& Melloul D 1999 Impaired beta-cell functions induced by chronic exposure of cultured human pancreatic islets to high glucose. Diabetes 48 1230-1236. (https://doi.org/10.2337/diabetes.48.6.1230)

Martens GA \& Pipeleers D 2009 Glucose, regulator of survival and phenotype of pancreatic beta cells. Vitamins and Hormones $\mathbf{8 0}$ 507-539.

Martens GA, Cai Y, Hinke S, Stange G, Van de Casteele M \& Pipeleers D 2005 Glucose suppresses superoxide generation in metabolically responsive pancreatic beta cells. Journal of Biological Chemistry $\mathbf{2 8 0}$ 20389-20396. (https://doi.org/10.1074/jbc.M411869200)

Martens GA, Motte E, Kramer G, Stange G, Gaarn LW, Hellemans K, Nielsen JH, Aerts JM, Ling Z \& Pipeleers D 2014 Functional characteristics of neonatal rat beta cells with distinct markers. Journal of Molecular Endocrinology 52 11-28. (https://doi.org/10.1530/JME-130106)

Martinez-Sanchez A, Nguyen-Tu MS \& Rutter GA 2015 DICER inactivation identifies pancreatic beta-cell "disallowed" genes targeted by microRNAs. Molecular Endocrinology 29 1067-1079. (https://doi. org/10.1210/me.2015-1059)

Martinez-Sanchez A, Pullen TJ, Chabosseau P, Zhang Q, Haythorne E, Cane MC, Nguyen-Tu MS, Sayers SR \& Rutter GA 2016 Disallowance of Acot7 in beta-cells is required for normal glucose tolerance and insulin secretion. Diabetes 65 1268-1282. (https://doi.org/10.2337/ db15-1240)

Martinez SC, Cras-Meneur C, Bernal-Mizrachi E \& Permutt MA 2006 Glucose regulates Foxo1 through insulin receptor signaling in the pancreatic islet beta-cell. Diabetes 55 1581-1591. (https://doi. org/10.2337/db05-0678)
Martinez SC, Tanabe K, Cras-Meneur C, Abumrad NA, Bernal-Mizrachi E \& Permutt MA 2008 Inhibition of Foxo1 protects pancreatic islet beta-cells against fatty acid and endoplasmic reticulum stress-induced apoptosis. Diabetes 57 846-859. (https://doi.org/10.2337/db07-0595)

Masini M, Marselli L, Bugliani M, Martino L, Masiello P, Marchetti P \& De Tata V 2012 Ultrastructural morphometric analysis of insulin secretory granules in human type 2 diabetes. Acta Diabetologica 49 (Supplement 1) S247-S252. (https://doi.org/10.1007/s00592-0120446-6)

Matschinsky FM 2009 Assessing the potential of glucokinase activators in diabetes therapy. Nature Reviews Drug Discovery 8 399-416. (https://doi.org/10.1038/nrd2850)

Matsuoka TA, Kaneto H, Miyatsuka T, Yamamoto T, Yamamoto K, Kato K, Shimomura I, Stein R \& Matsuhisa M 2010 Regulation of MafA expression in pancreatic beta-cells in $\mathrm{db} / \mathrm{db}$ mice with diabetes. Diabetes 59 1709-1720. (https://doi.org/10.2337/db08-0693)

Melkman-Zehavi T, Oren R, Kredo-Russo S, Shapira T, Mandelbaum AD, Rivkin N, Nir T, Lennox KA, Behlke MA, Dor Y, et al. 2011 miRNAs control insulin content in pancreatic beta-cells via downregulation of transcriptional repressors. EMBO Journal 30 835-845. (https://doi. org/10.1038/emboj.2010.361)

Mitchell RK, Nguyen-Tu MS, Chabosseau P, Callingham RM, Pullen TJ, Cheung R, Leclerc I, Hodson DJ \& Rutter GA 2017 The transcription factor Pax6 is required for pancreatic beta cell identity, glucoseregulated ATP synthesis, and $\mathrm{Ca} 2+$ dynamics in adult mice. Journal of Biological Chemistry 292 8892-8906. (https://doi.org/10.1074/jbc. M117.784629)

Moates JM, Nanda S, Cissell MA, Tsai MJ \& Stein R 2003 BETA2 activates transcription from the upstream glucokinase gene promoter in islet beta-cells and gut endocrine cells. Diabetes 52 403-408. (https://doi. org/10.2337/diabetes.52.2.403)

Molina J, Rodriguez-Diaz R, Fachado A, Jacques-Silva MC, Berggren PO \& Caicedo A 2014 Control of insulin secretion by cholinergic signaling in the human pancreatic islet. Diabetes 63 2714-2726. (https://doi. org/10.2337/db13-1371)

Moore CE, Omikorede O, Gomez E, Willars GB \& Herbert TP 2011 PERK activation at low glucose concentration is mediated by SERCA pump inhibition and confers preemptive cytoprotection to pancreatic betacells. Molecular Endocrinology 25 315-326. (https://doi.org/10.1210/ me.2010-0309)

Moran A, Zhang HJ, Olson LK, Harmon JS, Poitout V \& Robertson RP 1997 Differentiation of glucose toxicity from beta cell exhaustion during the evolution of defective insulin gene expression in the pancreatic islet cell line, HIT-T15. Journal of Clinical Investigation 99 534-539. (https://doi.org/10.1172/JCI119190)

Movassat J, Saulnier C, Serradas P \& Portha B 1997 Impaired development of pancreatic beta-cell mass is a primary event during the progression to diabetes in the GK rat. Diabetologia 40 916-925. (https://doi. org/10.1007/s001250050768)

Nagamatsu S, Nakamichi Y, Yamamura C, Matsushima S, Watanabe T, Ozawa S, Furukawa H \& Ishida H 1999 Decreased expression of t-SNARE, syntaxin 1, and SNAP-25 in pancreatic beta-cells is involved in impaired insulin secretion from diabetic GK rat islets: restoration of decreased t-SNARE proteins improves impaired insulin secretion. Diabetes 48 2367-2373. (https://doi.org/10.2337/diabetes.48.12.2367)

Nair R, Teo WS, Mittal V \& Swarbrick A 2014 ID proteins regulate diverse aspects of cancer progression and provide novel therapeutic opportunities. Molecular Therapy 22 1407-1415. (https://doi. org/10.1038/mt.2014.83)

Nesca V, Guay C, Jacovetti C, Menoud V, Peyot ML, Laybutt DR, Prentki M \& Regazzi R 2013 Identification of particular groups of microRNAs that positively or negatively impact on beta cell function in obese models of type 2 diabetes. Diabetologia 56 2203-2212. (https://doi.org/10.1007/s00125-013-2993-y)

Nesher R, Gross DJ, Donath MY, Cerasi E \& Kaiser N 1999 Interaction between genetic and dietary factors determines $\beta$-cell function in 
Psammomys obesus, an animal model of type 2 diabetes. Diabetes 48 731-737. (https://doi.org/10.2337/diabetes.48.4.731)

Newgard CB 1996 Regulatory role of glucose transport and phosphorylation in pancreatic islet $\beta$-cells. Diabetes Reviews 4 191-206.

Newgard CB \& McGarry JD 1995 Metabolic coupling factors in pancreatic $\beta$-cell signal transduction. Annual Review of Biochemistry 64 689-719. (https://doi.org/10.1146/annurev.bi.64.070195.003353)

Nielsen K, Karlsen AE, Deckert M, Madsen OD, Serup P, MandrupPoulsen T \& Nerup J 1999 Beta-cell maturation leads to in vitro sensitivity to cytotoxins. Diabetes 48 2324-2332. (https://doi. org/10.2337/diabetes.48.12.2324)

Nielsen K, Kruhoffer M, Orntoft T, Sparre T, Wang H, Wollheim C, Jorgensen MC, Nerup J \& Karlsen AE 2004 Gene expression profiles during beta cell maturation and after IL-1beta exposure reveal important roles of Pdx-1 and Nkx6.1 for IL-1beta sensitivity. Diabetologia 47 2185-2199. (https://doi.org/10.1007/s00125-0041578-1)

Nordmann TM, Dror E, Schulze F, Traub S, Berishvili E, Barbieux C, Boni-Schnetzler M \& Donath MY 2017 The role of inflammation in beta-cell dedifferentiation. Scientific Reports 7 6285. (https://doi. org/10.1038/s41598-017-06731-w)

Oberkofler H, Hafner M, Felder T, Krempler F \& Patsch W 2009 Transcriptional co-activator peroxisome proliferator-activated receptor (PPAR)gamma co-activator-1beta is involved in the regulation of glucose-stimulated insulin secretion in INS-1E cells. Journal of Molecular Medicine 87 299-306. (https://doi.org/10.1007/s00109-0080425-0)

Ofori JK, Salunkhe VA, Bagge A, Vishnu N, Nagao M, Mulder H, Wollheim CB, Eliasson L \& Esguerra JL 2017 Elevated miR-130a/ miR130b/miR-152 expression reduces intracellular ATP levels in the pancreatic beta cell. Scientific Reports 7 44986. (https://doi. org/10.1038/srep44986)

Okamoto H, Hribal ML, Lin HV, Bennett WR, Ward A \& Accili D 2006 Role of the forkhead protein FoxO1 in beta cell compensation to insulin resistance. Journal of Clinical Investigation 116 775-782. (https://doi.org/10.1172/JCI24967)

Okauchi S, Shimoda M, Obata A, Kimura T, Hirukawa H, Kohara K, Mune T, Kaku K \& Kaneto H 2016 Protective effects of SGLT2 inhibitor luseogliflozin on pancreatic beta-cells in obese type 2 diabetic $\mathrm{db} / \mathrm{db}$ mice. Biochemical and Biophysical Research Communications 470 772-782. (https://doi.org/10.1016/j. bbrc.2015.10.109)

Olson LK, Sharma A, Peshavaria M, Wright CV, Towle HC, Rodertson RP \& Stein R 1995 Reduction of insulin gene transcription in HITT15 beta cells chronically exposed to a supraphysiologic glucose concentration is associated with loss of STF-1 transcription factor expression. PNAS 92 9127-9131. (https://doi.org/10.1073/ pnas.92.20.9127)

Olson LK, Qian J \& Poitout V 1998 Glucose rapidly and reversibly decreases INS-1 cell insulin gene transcription via decrements in STF-1 and C1 activator transcription factor activity. Molecular Endocrinology 12 207-219. (https://doi.org/10.1210/mend.12.2.0066)

Omikorede O, Qi C, Gorman T, Chapman P, Yu A, Smith DM \& Herbert TP 2013 ER stress in rodent islets of Langerhans is concomitant with obesity and beta-cell compensation but not with beta-cell dysfunction and diabetes. Nutrition and Diabetes 3 e93. (https://doi.org/10.1038/nutd.2013.35)

Ostenson CG, Gaisano H, Sheu L, Tibell A \& Bartfai T 2006 Impaired gene and protein expression of exocytotic soluble N-ethylmaleimide attachment protein receptor complex proteins in pancreatic islets of type 2 diabetic patients. Diabetes 55 435-440. (https://doi. org/10.2337/diabetes.55.02.06.db04-1575)

Otonkoski T, Jiao H, Kaminen-Ahola N, Tapia-Paez I, Ullah MS, Parton LE, Schuit F, Quintens R, Sipila I, Mayatepek E, et al. 2007 Physical exercise-induced hypoglycemia caused by failed silencing of monocarboxylate transporter 1 in pancreatic beta cells. American Journal of Human Genetics 81 467-474. (https://doi. org/10.1086/520960)

Oyadomari S, Koizumi A, Takeda K, Gotoh T, Akira S, Araki E \& Mori M 2002 Targeted disruption of the Chop gene delays endoplasmic reticulum stress-mediated diabetes. Journal of Clinical Investigation 109 525-532. (https://doi.org/10.1172/JCI0214550)

Parton LE, McMillen PJ, Shen Y, Docherty E, Sharpe E, Diraison F, Briscoe CP \& Rutter GA 2006 Limited role for SREBP-1c in defective glucose-induced insulin secretion from Zucker diabetic fatty rat islets: a functional and gene profiling analysis. American Journal of Physiology: Endocrinology and Metabolism 291 E982-E994. (https://doi. org/10.1152/ajpendo.00067.2006)

Pascal SM, Guiot Y, Pelengaris S, Khan M \& Jonas JC 2008 Effects of c-MYC activation on glucose stimulus-secretion coupling events in mouse pancreatic islets. American Journal of Physiology: Endocrinology and Metabolism 295 E92-E102. (https://doi.org/10.1152/ ajpendo.90235.2008)

Pascal SM, Veiga-da-Cunha M, Gilon P, Van Schaftingen E \& Jonas JC 2010 Effects of fructosamine-3-kinase deficiency on function and survival of mouse pancreatic islets after prolonged culture in high glucose or ribose concentrations. American Journal of Physiology: Endocrinology and Metabolism 298 E586-E596. (https://doi. org/10.1152/ajpendo.00503.2009)

Pedersen JK, Nelson SB, Jorgensen MC, Henseleit KD, Fujitani Y, Wright CV, Sander M, Serup P \& Beta Cell Biology Consortium 2005 Endodermal expression of Nkx6 genes depends differentially on Pdx1. Developmental Biology 288 487-501. (https://doi.org/10.1016/j. ydbio.2005.10.001)

Pertusa JA, Nesher R, Kaiser N, Cerasi E, Henquin JC \& Jonas JC 2002 Increased glucose sensitivity of stimulus-secretion coupling in islets from Psammomys obesus after diet induction of diabetes. Diabetes $\mathbf{5 1}$ 2552-2560. (https://doi.org/10.2337/diabetes.51.8.2552)

Pi J, Bai Y, Zhang Q, Wong V, Floering LM, Daniel K, Reece JM, Deeney JT, Andersen ME, Corkey BE, et al. 2007 Reactive oxygen species as a signal in glucose-stimulated insulin secretion. Diabetes 56 1783-1791. (https://doi.org/10.2337/db06-1601)

Piccand J, Strasser P, Hodson DJ, Meunier A, Ye T, Keime C, Birling MC, Rutter GA \& Gradwohl G 2014 Rfx6 maintains the functional identity of adult pancreatic beta cells. Cell Reports 9 2219-2232. (https://doi. org/10.1016/j.celrep.2014.11.033)

Pick A, Clark J, Kubstrup C, Levisetti M, Pugh W, Bonner-Weir S \& Polonsky KS 1998 Role of apoptosis in failure of beta-cell mass compensation for insulin resistance and beta-cell defects in the male Zucker diabetic fatty rat. Diabetes 47 358-364. (https://doi. org/10.2337/diabetes.47.3.358)

Pildes RS, Hart RJ, Warrner R \& Cornblath M 1969 Plasma insulin response during oral glucose tolerance tests in newborns of normal and gestational diabetic mothers. Pediatrics 44 76-83.

Pino MF, Ye DZ, Linning KD, Green CD, Wicksteed B, Poitout V \& Olson LK 2005 Elevated glucose attenuates human insulin gene promoter activity in INS-1 pancreatic beta-cells via reduced nuclear factor binding to the A5/core and Z element. Molecular Endocrinology 19 1343-1360. (https://doi.org/10.1210/me.2003-0493)

Piro S, Anello M, Di Pietro C, Lizzio MN, Patane G, Rabuazzo AM, Vigneri R, Purrello M \& Purrello F 2002 Chronic exposure to free fatty acids or high glucose induces apoptosis in rat pancreatic islets: possible role of oxidative stress. Metabolism 51 1340-1347. (https://doi.org/10.1053/meta.2002.35200)

Pirot P, Naamane N, Libert F, Magnusson NE, Orntoft TF, Cardozo AK \& Eizirik DL 2007 Global profiling of genes modified by endoplasmic reticulum stress in pancreatic beta cells reveals the early degradation of insulin mRNAs. Diabetologia 50 1006-1014. (https://doi. org/10.1007/s00125-007-0609-0)

Poitout V, Olson LK \& Robertson RP 1996 Chronic exposure of betaTC-6 cells to supraphysiologic concentrations of glucose decreases binding http://joe.endocrinology-journals.org

https://doi.org/10.1530/JOE-17-0516 (c) 2018 Society for Endocrinology Published by Bioscientifica Ltd. Printed in Great Britain 
of the RIPE3b1 insulin gene transcription activator. Journal of Clinical Investigation 97 1041-1046. (https://doi.org/10.1172/JCI118496)

Poy MN, Eliasson L, Krutzfeldt J, Kuwajima S, Ma X, Macdonald PE, Pfeffer S, Tuschl T, Rajewsky N, Rorsman P, et al. 2004 A pancreatic islet-specific microRNA regulates insulin secretion. Nature $\mathbf{4 3 2}$ 226-230. (https://doi.org/10.1038/nature03076)

Pullen TJ, Khan AM, Barton G, Butcher SA, Sun G \& Rutter GA 2010 Identification of genes selectively disallowed in the pancreatic islet. Islets 2 89-95. (https://doi.org/10.4161/isl.2.2.11025)

Pullen TJ, da Silva Xavier G, Kelsey G \& Rutter GA 2011 miR-29a and miR-29b contribute to pancreatic beta-cell-specific silencing of monocarboxylate transporter 1 (Mct1). Molecular and Cellular Biology 31 3182-3194. (https://doi.org/10.1128/MCB.01433-10)

Pullen TJ, Sylow L, Sun G, Halestrap AP, Richter EA \& Rutter GA 2012 Overexpression of monocarboxylate transporter-1 (SLC16A1) in mouse pancreatic beta-cells leads to relative hyperinsulinism during exercise. Diabetes 61 1719-1725. (https://doi.org/10.2337/db11-1531)

Pullen TJ, Huising MO \& Rutter GA 2017 Analysis of purified pancreatic islet beta and alpha cell transcriptomes reveals 11 beta-hydroxysteroid dehydrogenase (Hsd11b1) as a novel disallowed gene. Frontiers in Genetics 841.

Puri S \& Hebrok M 2010 Cellular plasticity within the pancreas - lessons learned from development. Developmental Cell 18 342-356. (https://doi.org/10.1016/j.devcel.2010.02.005)

Puri S, Akiyama H \& Hebrok M 2013 VHL-mediated disruption of Sox9 activity compromises beta-cell identity and results in diabetes mellitus. Genes and Development 27 2563-2575. (https://doi. org/10.1101/gad.227785.113)

Qian B, Wang H, Men X, Zhang W, Cai H, Xu S, Xu Y, Ye L, Wollheim CB \& Lou J 2008 TRIB3 is implicated in glucotoxicity- and ER-stressinduced beta-cell apoptosis. Journal of Endocrinology 199 407-416. (https://doi.org/10.1677/JOE-08-0331)

Rahier J, Guiot Y, Goebbels RM, Sempoux C \& Henquin JC 2008 Pancreatic $\beta$-cell mass in European subjects with type 2 diabetes. Diabetes, Obesity and Metabolism 10 (Supplement 4) 32-42. (https://doi.org/10.1111/j.1463-1326.2008.00969.x)

Robertson RP \& Harmon JS 2006 Diabetes, glucose toxicity, and oxidative stress: a case of double jeopardy for the pancreatic islet beta cell. Free Radical Biology and Medicine 41 177-184. (https://doi.org/10.1016/j. freeradbiomed.2005.04.030)

Robertson RP, Zhang HJ, Pyzdrowski KL \& Walseth TF 1992 Preservation of insulin mRNA levels and insulin secretion in HIT cells by avoidance of chronic exposure to high glucose concentrations. Journal of Clinical Investigation 90 320-325. (https://doi.org/10.1172/ JCI115865)

Robson SC, Ward L, Brown H, Turner H, Hunter E, Pelengaris S \& Khan M 2011 Deciphering c-MYC-regulated genes in two distinct tissues. BMC Genomics 12 476. (https://doi.org/10.1186/1471-2164-12-476)

Roche E, Assimacopoulos-Jeannet F, Witters LA, Perruchoud B, Yaney G, Corkey B, Asfari M \& Prentki M 1997 Induction by glucose of genes coding for glycolytic enzymes in a pancreatic beta-cell line (INS-1). Journal of Biological Chemistry 272 3091-3098. (https://doi. org/10.1074/jbc.272.5.3091)

Roduit R, Morin J, Masse F, Segall L, Roche E, Newgard CB, Assimacopoulos-Jeannet F \& Prentki M 2000 Glucose down-regulates the expression of the peroxisome proliferator-activated receptor-alpha gene in the pancreatic beta -cell. Journal of Biological Chemistry $\mathbf{2 7 5}$ 35799-35806. (https://doi.org/10.1074/jbc.M006001200)

Roesch A, Paschen A, Landsberg J, Helfrich I, Becker JC \& Schadendorf D 2016 Phenotypic tumour cell plasticity as a resistance mechanism and therapeutic target in melanoma. European Journal of Cancer 59 109-112. (https://doi.org/10.1016/j.ejca.2016.02.023)

Roma LP, Duprez J, Takahashi HK, Gilon P, Wiederkehr A \& Jonas JC 2012 Dynamic measurements of mitochondrial hydrogen peroxide concentration and glutathione redox state in rat pancreatic beta-cells using ratiometric fluorescent proteins: confounding effects of $\mathrm{pH}$ with
HyPer but not roGFP1. Biochemical Journal 441 971-978. (https://doi. org/10.1042/BJ20111770)

Rorsman P, Arkhammar P, Bokvist K, Hellerstrom C, Nilsson T, Welsh M, Welsh N \& Berggren PO 1989 Failure of glucose to elicit a normal secretory response in fetal pancreatic beta cells results from glucose insensitivity of the ATP-regulated K+ channels. PNAS 86 4505-4509. (https://doi.org/10.1073/pnas.86.12.4505)

Rutter GA, Pullen TJ, Hodson DJ \& Martinez-Sanchez A 2015 Pancreatic beta-cell identity, glucose sensing and the control of insulin secretion. Biochemical Journal 466 203-218. (https://doi.org/10.1042/ BJ20141384)

Sakuraba H, Mizukami H, Yagihashi N, Wada R, Hanyu C \& Yagihashi S 2002 Reduced beta-cell mass and expression of oxidative stressrelated DNA damage in the islet of Japanese Type II diabetic patients. Diabetologia 45 85-96. (https://doi.org/10.1007/s125-0028248-z)

Samaras SE, Cissell MA, Gerrish K, Wright CV, Gannon M \& Stein R 2002 Conserved sequences in a tissue-specific regulatory region of the pdx-1 gene mediate transcription in Pancreatic beta cells: role for hepatocyte nuclear factor 3 beta and Pax6. Molecular and Cellular Biology 22 4702-4713. (https://doi.org/10.1128/МСB.22.13.47024713.2002)

Samaras SE, Zhao L, Means A, Henderson E, Matsuoka TA \& Stein R 2003 The islet beta cell-enriched RIPE3b1/Maf transcription factor regulates pdx-1 expression. Journal of Biological Chemistry 278 12263-12270. (https://doi.org/10.1074/jbc.M210801200)

Sarre A, Gabrielli J, Vial G, Leverve XM \& Assimacopoulos-Jeannet F 2012 Reactive oxygen species are produced at low glucose and contribute to the activation of AMPK in insulin-secreting cells. Free Radical Biology and Medicine 52 142-150. (https://doi.org/10.1016/j. freeradbiomed.2011.10.437)

Sasaki M, Fujimoto S, Sato Y, Nishi Y, Mukai E, Yamano G, Sato H, Tahara Y, Ogura K, Nagashima K, et al. 2013 Reduction of reactive oxygen species ameliorates metabolism-secretion coupling in islets of diabetic GK rats by suppressing lactate overproduction. Diabetes $\mathbf{6 2}$ 1996-2003. (https://doi.org/10.2337/db12-0903)

Sato Y, Endo H, Okuyama H, Takeda T, Iwahashi H, Imagawa A, Yamagata K, Shimomura I \& Inoue M 2011 Cellular hypoxia of pancreatic $\beta$-cells due to high levels of oxygen consumption for insulin secretion in vitro. Journal of Biological Chemistry 28612524 12532. (https://doi.org/10.1074/jbc.M110.194738)

Sato Y, Inoue M, Yoshizawa T \& Yamagata K 2014 Moderate hypoxia induces beta-cell dysfunction with HIF-1-independent gene expression changes. PLOS ONE 9 e114868. (https://doi.org/10.1371/ journal.pone.0114868)

Sato Y, Tsuyama T, Sato C, Karim MF, Yoshizawa T, Inoue M \& Yamagata K 2017 Hypoxia reduces HNF4alpha/MODY1 protein expression in pancreatic beta-cells by activating AMP-activated protein kinase. Journal of Biological Chemistry 292 8716-8728. (https://doi. org/10.1074/jbc.M116.767574)

Saxena G, Chen J \& Shalev A 2010 Intracellular shuttling and mitochondrial function of thioredoxin-interacting protein. Journal of Biological Chemistry 285 3997-4005. (https://doi.org/10.1074/jbc. M109.034421)

Schaffer AE, Taylor BL, Benthuysen JR, Liu J, Thorel F, Yuan W, Jiao Y, Kaestner KH, Herrera PL, Magnuson MA, et al. 2013 Nkx6.1 controls a gene regulatory network required for establishing and maintaining pancreatic Beta cell identity. PLoS Genetics 9 e1003274. (https://doi. org/10.1371/journal.pgen.1003274)

Schroder M \& Kaufman RJ 2005 ER stress and the unfolded protein response. Mutation Research 569 29-63. (https://doi.org/10.1016/j. mrfmmm.2004.06.056)

Schuit FC, In't Veld PA \& Pipeleers DG 1988 Glucose stimulates proinsulin biosynthesis by a dose-dependent recruitment of pancreatic beta cells. PNAS 85 3865-3869. (https://doi.org/10.1073/ pnas.85.11.3865)
๑) 2018 Society for Endocrinology Published by Bioscientifica Ltd. Printed in Great Britain 
Schuit F, De Vos A, Farfari S, Moens K, Pipeleers D, Brun T \& Prentki M 1997 Metabolic fate of glucose in purified islet cells. Glucose-regulated anaplerosis in beta cells. Journal of Biological Chemistry $\mathbf{2 7 2}$ 18572-18579. (https://doi.org/10.1074/jbc.272.30.18572)

Schuit F, Moens K, Heimberg H \& Pipeleers D 1999 Cellular origin of hexokinase in pancreatic islets. Journal of Biological Chemistry 274 32803-32809. (https://doi.org/10.1074/jbc.274.46.32803)

Schuit F, Flamez D, De Vos A \& Pipeleers D 2002 Glucose-regulated gene expression maintaining the glucose-responsive state of beta-cells. Diabetes 51 (Supplement 3) S326-S332. (https://doi.org/10.2337/ diabetes.51.2007.S326)

Schuit F, Van Lommel L, Granvik M, Goyvaerts L, de Faudeur G, Schraenen A \& Lemaire K 2012 beta-cell-specific gene repression: a mechanism to protect against inappropriate or maladjusted insulin secretion? Diabetes 61 969-975. (https://doi.org/10.2337/db11-1564)

Sebastiani G, Po A, Miele E, Ventriglia G, Ceccarelli E, Bugliani M, Marselli L, Marchetti P, Gulino A, Ferretti E, et al. 2015 MicroRNA$124 \mathrm{a}$ is hyperexpressed in type 2 diabetic human pancreatic islets and negatively regulates insulin secretion. Acta Diabetologica 52 523-530. (https://doi.org/10.1007/s00592-014-0675-y)

Sekine N, Cirulli V, Regazzi R, Brown LJ, Gine E, Tamarit-Rodriguez J, Girotti M, Marie S, MacDonald MJ \& Wollheim CB 1994 Low lactate dehydrogenase and high mitochondrial glycerol phosphate dehydrogenase in pancreatic $\beta$-cells. Potential role in nutrient sensing. Journal of Biological Chemistry 269 4895-4902.

Seo HY, Kim YD, Lee KM, Min AK, Kim MK, Kim HS, Won KC, Park JY, Lee KU, Choi HS, et al. 2008 Endoplasmic reticulum stress-induced activation of activating transcription factor 6 decreases insulin gene expression via up-regulation of orphan nuclear receptor small heterodimer partner. Endocrinology 149 3832-3841. (https://doi. org/10.1210/en.2008-0015)

Seufert J, Weir GC \& Habener JF 1998 Differential expression of the insulin gene transcriptional repressor CCAAT/enhancer-binding protein beta and transactivator islet duodenum homeobox-1 in rat pancreatic beta cells during the development of diabetes mellitus. Journal of Clinical Investigation $1012528-2539$. (https://doi. org/10.1172/JCI2401)

Seymour PA \& Sander M 2011 Historical perspective: beginnings of the beta-cell: current perspectives in beta-cell development. Diabetes 60 364-376. (https://doi.org/10.2337/db10-1068)

Shalev A, Pise-Masison CA, Radonovich M, Hoffmann SC, Hirshberg B, Brady JN \& Harlan DM 2002 Oligonucleotide microarray analysis of intact human pancreatic islets: identification of glucoseresponsive genes and a highly regulated TGFbeta signaling pathway. Endocrinology 143 3695-3698. (https://doi.org/10.1210/en.2002220564)

Sharma A, Olson LK, Robertson RP \& Stein R 1995 The reduction of insulin gene transcription in HIT-T15 beta cells chronically exposed to high glucose concentration is associated with the loss of RIPE3b1 and STF-1 transcription factor expression. Molecular Endocrinology 9 1127-1134.

Sheng C, Li F, Lin Z, Zhang M, Yang P, Bu L, Sheng H, Li H \& Qu S 2016 Reversibility of beta-cell-specific transcript factors expression by longterm caloric restriction in $\mathrm{db} / \mathrm{db}$ mouse. Journal of Diabetes Research 20166035046

Shih DQ, Screenan S, Munoz KN, Philipson L, Pontoglio M, Yaniv M, Polonsky KS \& Stoffel M 2001 Loss of HNF-1alpha function in mice leads to abnormal expression of genes involved in pancreatic islet development and metabolism. Diabetes 50 2472-2480. (https://doi. org/10.2337/diabetes.50.11.2472)

Shih DQ, Heimesaat M, Kuwajima S, Stein R, Wright CV \& Stoffel M 2002 Profound defects in pancreatic beta-cell function in mice with combined heterozygous mutations in Pdx-1, Hnf-1alpha, and Hnf3beta. PNAS 99 3818-3823. (https://doi.org/10.1073/pnas.062605899)

Shojima N, Hara K, Fujita H, Horikoshi M, Takahashi N, Takamoto I, Ohsugi M, Aburatani H, Noda M, Kubota N, et al. 2012 Depletion of homeodomain-interacting protein kinase 3 impairs insulin secretion and glucose tolerance in mice. Diabetologia 55 3318-3330. (https:// doi.org/10.1007/s00125-012-2711-1)

Shu L, Matveyenko AV, Kerr-Conte J, Cho JH, McIntosh CH \& Maedler K 2009 Decreased TCF7L2 protein levels in type 2 diabetes mellitus correlate with downregulation of GIP- and GLP-1 receptors and impaired beta-cell function. Human Molecular Genetics 18 2388-2399. (https://doi.org/10.1093/hmg/ddp178)

Song B, Scheuner D, Ron D, Pennathur S \& Kaufman RJ 2008 Chop deletion reduces oxidative stress, improves beta cell function, and promotes cell survival in multiple mouse models of diabetes. Journal of Clinical Investigation 118 3378-3389. (https://doi.org/10.1172/ JCI34587)

Spijker HS, Ravelli RB, Mommaas-Kienhuis AM, van Apeldoorn AA, Engelse MA, Zaldumbide A, Bonner-Weir S, Rabelink TJ, Hoeben RC, Clevers H, et al. 2013 Conversion of mature human beta-cells into glucagon-producing alpha-cells. Diabetes 62 2471-2480. (https://doi. org/10.2337/db12-1001)

Spijker HS, Song H, Ellenbroek JH, Roefs MM, Engelse MA, Bos E, Koster AJ, Rabelink TJ, Hansen BC, Clark A, et al. 2015 Loss of betacell identity occurs in type 2 diabetes and is associated with islet amyloid deposits. Diabetes 64 2928-2938. (https://doi.org/10.2337/ db14-1752)

Stancill JS, Cartailler JP, Clayton HW, O'Connor JT, Dickerson MT, Dadi PK, Osipovich AB, Jacobson DA \& Magnuson MA 2017 Chronic beta-cell depolarization impairs beta-cell identity by disrupting a network of Ca2+-regulated genes. Diabetes 66 2175-2187. (https://doi. org/10.2337/db16-1355)

Stanger BZ \& Hebrok M 2013 Control of cell identity in pancreas development and regeneration. Gastroenterology 144 1170-1179. (https://doi.org/10.1053/j.gastro.2013.01.074)

Sun LL, Jiang BG, Li WT, Zou JJ, Shi YQ \& Liu ZM 2011 MicroRNA-15a positively regulates insulin synthesis by inhibiting uncoupling protein-2 expression. Diabetes Research and Clinical Practice 91 94-100. (https://doi.org/10.1016/j.diabres.2010.11.006)

Sund NJ, Vatamaniuk MZ, Casey M, Ang SL, Magnuson MA, Stoffers DA, Matschinsky FM \& Kaestner KH 2001 Tissue-specific deletion of Foxa2 in pancreatic beta cells results in hyperinsulinemic hypoglycemia. Genes and Development 15 1706-1715. (https://doi.org/10.1101/ gad.901601)

Swisa A, Avrahami D, Eden N, Zhang J, Feleke E, Dahan T, Cohen-Tayar Y, Stolovich-Rain M, Kaestner KH, Glaser B, et al. 2017 PAX6 maintains beta cell identity by repressing genes of alternative islet cell types. Journal of Clinical Investigation 127 230-243. (https://doi.org/10.1172/ JCI88015)

Synofzik M, Haack TB, Kopajtich R, Gorza M, Rapaport D, Greiner M, Schonfeld C, Freiberg C, Schorr S, Holl RW, et al. 2014 Absence of BiP co-chaperone DNAJC3 causes diabetes mellitus and multisystemic neurodegeneration. American Journal of Human Genetics 95 689-697. (https://doi.org/10.1016/j.ajhg.2014.10.013)

Szabat M, Kalynyak TB, Lim GE, Chu KY, Yang YH, Asadi A, Gage BK, Ao Z, Warnock GL, Piret JM, et al. 2011 Musashi expression in beta-cells coordinates insulin expression, apoptosis and proliferation in response to endoplasmic reticulum stress in diabetes. Cell Death and Disease 2 e232. (https://doi.org/10.1038/ cddis.2011.119)

Talchai C, Xuan S, Lin HV, Sussel L \& Accili D 2012 Pancreatic beta cell dedifferentiation as a mechanism of diabetic beta cell failure. Cell $\mathbf{1 5 0}$ 1223-1234. (https://doi.org/10.1016/j.cell.2012.07.029)

Tan C, Tuch BE, Tu J \& Brown SA 2002 Role of NADH shuttles in glucoseinduced insulin secretion from fetal beta-cells. Diabetes $\mathbf{5 1}$ 2989-2996. (https://doi.org/10.2337/diabetes.51.10.2989)

Tanaka Y, Gleason CE, Tran PO, Harmon JS \& Robertson RP 1999 Prevention of glucose toxicity in HIT-T15 cells and Zucker diabetic fatty rats by antioxidants. PNAS 96 10857-10862. (https://doi. org/10.1073/pnas.96.19.10857)
(C) 2018 Society for Endocrinology Published by Bioscientifica Ltd. Printed in Great Britain 
Taneera J, Lang S, Sharma A, Fadista J, Zhou Y, Ahlqvist E, Jonsson A, Lyssenko V, Vikman P, Hansson O, et al. 2012 A systems genetics approach identifies genes and pathways for type 2 diabetes in human islets. Cell Metabolism 16 122-134. (https://doi.org/10.1016/j. cmet.2012.06.006)

Tang X, Muniappan L, Tang G \& Ozcan S 2009 Identification of glucoseregulated miRNAs from pancreatic \{beta\} cells reveals a role for miR-30d in insulin transcription. RNA 15 287-293. (https://doi. org/10.1261/rna.1211209)

Tang C, Koulajian K, Schuiki I, Zhang L, Desai T, Ivovic A, Wang P, Robson-Doucette C, Wheeler MB, Minassian B, et al. 2012 Glucoseinduced beta cell dysfunction in vivo in rats: link between oxidative stress and endoplasmic reticulum stress. Diabetologia.

Taylor BL, Liu FF \& Sander M 2013 Nkx6.1 is essential for maintaining the functional state of pancreatic beta cells. Cell Reports 4 1262-1275. (https://doi.org/10.1016/j.celrep.2013.08.010)

Thorens B 2015 GLUT2, glucose sensing and glucose homeostasis. Diabetologia 58 221-232. (https://doi.org/10.1007/s00125-014-3451-1)

Thorens B, Wu YJ, Leahy JL \& Weir GC 1992 The loss of GLUT2 expression by glucose-unresponsive beta cells of $\mathrm{db} / \mathrm{db}$ mice is reversible and is induced by the diabetic environment. Journal of Clinical Investigation 90 77-85. (https://doi.org/10.1172/JCI115858)

Thorrez L, Laudadio I, Van Deun K, Quintens R, Hendrickx N, Granvik M, Lemaire K, Schraenen A, Van Lommel L, Lehnert S, et al. 2011 Tissuespecific disallowance of housekeeping genes: the other face of cell differentiation. Genome Research 21 95-105. (https://doi.org/10.1101/ gr.109173.110)

Tiedge M, Lortz S, Drinkgern J \& Lenzen S 1997 Relation between antioxidant enzyme gene expression and antioxidative defense status of insulin-producing cells. Diabetes 46 1733-1742. (https://doi. org/10.2337/diab.46.11.1733)

Tokuyama Y, Sturis J, DePaoli AM, Takeda J, Stoffel M, Tang J, Sun X, Polonsky KS \& Bell GI 1995 Evolution of $\beta$-cell dysfunction in the male Zucker diabetic fatty rat. Diabetes 44 1447-1457. (https://doi. org/10.2337/diab.44.12.1447)

Tonooka N, Oseid E, Zhou H, Harmon JS \& Robertson RP 2007 Glutathione peroxidase protein expression and activity in human islets isolated for transplantation. Clinical Transplantation 21 767-772.

Torrejon-Escribano B, Escoriza J, Montanya E \& Blasi J 2011 Glucosedependent changes in SNARE protein levels in pancreatic beta-cells. Endocrinology 152 1290-1299. (https://doi.org/10.1210/en.2010-0898)

Trinh K, Minassian C, Lange AJ, O’Doherty RM \& Newgard CB 1997 Adenovirus-mediated expression of the catalytic subunit of glucose-6phosphatase in INS-1 cells. Effects on glucose cycling, glucose usage, and insulin secretion. Journal of Biological Chemistry 272 24837-24842. (https://doi.org/10.1074/jbc.272.40.24837)

Van de Casteele M, Kefas BA, Cai Y, Heimberg H, Scott DK, Henquin JC, Pipeleers D \& Jonas JC 2003 Prolonged culture in low glucose induces apoptosis of rat pancreatic $\beta$-cells through induction of c-myc. Biochemical and Biophysical Research Communications 312 937-944. (https://doi.org/10.1016/j.bbrc.2003.11.013)

Van Lommel L, Janssens K, Quintens R, Tsukamoto K, Vander Mierde D, Lemaire K, Denef C, Jonas JC, Martens G, Pipeleers D, et al. 2006 Probe-independent and direct quantification of insulin mRNA and growth hormone mRNA in enriched cell preparations. Diabetes $\mathbf{5 5}$ 3214-3220. (https://doi.org/10.2337/db06-0774)

Vander Mierde D, Scheuner D, Quintens R, Patel R, Song B, Tsukamoto K Beullens M, Kaufman RJ, Bollen M \& Schuit FC 2007 Glucose activates a protein phosphatase-1-mediated signaling pathway to enhance overall translation in pancreatic $\beta$-cells. Endocrinology 148 609-617. (https://doi.org/10.1210/en.2006-1012)

Waeber G, Thompson N, Nicod P \& Bonny C 1996 Transcriptional activation of the GLUT2 gene by the IPF-1/STF-1/IDX-1 homeobox factor. Molecular Endocrinology 10 1327-1334.

Walters SN, Luzuriaga J, Chan JY, Grey ST \& Laybutt DR 2013 Influence of chronic hyperglycemia on the loss of the unfolded protein response in transplanted islets. Journal of Molecular Endocrinology 51 225-232. (https://doi.org/10.1530/JME-13-0016)

Wang MY, Koyama K, Shimabukuro M, Mangelsdorf D, Newgard CB \& Unger RH 1998 Overexpression of leptin receptors in pancreatic islets of Zucker diabetic fatty rats restores GLUT-2, glucokinase, and glucose-stimulated insulin secretion. PNAS 95 11921-11926. (https://doi.org/10.1073/pnas.95.20.11921)

Wang H, Kouri G \& Wollheim CB 2005 ER stress and SREBP-1 activation are implicated in beta-cell glucolipotoxicity. Journal of Cell Science 118 3905-3915. (https://doi.org/10.1242/jcs.02513)

Wang H, Brun T, Kataoka K, Sharma AJ \& Wollheim CB 2007 MAFA controls genes implicated in insulin biosynthesis and secretion. Diabetologia 50 348-358. (https://doi.org/10.1007/s00125-006-0490-2)

Wang Z, York NW, Nichols CG \& Remedi MS 2014 Pancreatic beta cell dedifferentiation in diabetes and redifferentiation following insulin therapy. Cell Metabolism 19 872-882. (https://doi.org/10.1016/j. cmet.2014.03.010)

Weir GC, Aguayo-Mazzucato C \& Bonner-Weir S 2013 beta-cell dedifferentiation in diabetes is important, but what is it? Islets $\mathbf{5}$ 233-237. (https://doi.org/10.4161/isl.27494)

Wice BM, Bernal-Mizrachi E \& Permutt MA 2001 Glucose and other insulin secretagogues induce, rather than inhibit, expression of Id-1 and Id-3 in pancreatic islet beta cells. Diabetologia 44 453-463. (https://doi.org/10.1007/s001250051643)

Xu G, Kaneto H, Laybutt DR, Duvivier-Kali VF, Trivedi N, Suzuma K, King GL, Weir GC \& Bonner-Weir S 2007 Downregulation of GLP-1 and GIP receptor expression by hyperglycemia: possible contribution to impaired incretin effects in diabetes. Diabetes 56 1551-1558 (https://doi.org/10.2337/db06-1033)

Xu G, Chen J, Jing G \& Shalev A 2013 Thioredoxin-interacting protein regulates insulin transcription through microRNA-204. Nature Medicine 19 1141-1146. (https://doi.org/10.1038/nm.3287)

Xu T, Yang L, Yan C, Wang X, Huang P, Zhao F, Zhao L, Zhang M, Jia W, Wang X, et al. 2014 The IRE1alpha-XBP1 pathway regulates metabolic stress-induced compensatory proliferation of pancreatic beta-cells. Cell Research 24 1137-1140. (https://doi.org/10.1038/cr.2014.55)

Yang BT, Dayeh TA, Volkov PA, Kirkpatrick CL, Malmgren S, Jing X, Renstrom E, Wollheim CB, Nitert MD \& Ling C 2012 Increased DNA methylation and decreased expression of PDX-1 in pancreatic islets from patients with type 2 diabetes. Molecular Endocrinology 26 1203-1212. (https://doi.org/10.1210/me.2012-1004)

Yoon KH, Ko SH, Cho JH, Lee JM, Ahn YB, Song KH, Yoo SJ, Kang MI, Cha BY, Lee KW, et al. 2003 Selective $\beta$-cell loss and $\alpha$-cell expansion in patients with type 2 diabetes mellitus in Korea. Journal of Clinical Endocrinology and Metabolism 88 2300-2308. (https://doi.org/10.1210/ jc.2002-020735)

Yoshikawa H, Tajiri Y, Sako Y, Hashimato T, Umeda F \& Nawata H 2002 Glucosamine-induced beta-cell dysfunction: a possible involvement of glucokinase or glucose-transporter type 2. Pancreas 24 228-234. (https://doi.org/10.1097/00006676-200204000-00004)

Yuan Q, Tang W, Zhang X, Hinson JA, Liu C, Osei K \& Wang J 2012 Proinsulin atypical maturation and disposal induces extensive defects in mouse Ins2+/Akita beta-cells. PLoS ONE 7 e35098. (https://doi. org/10.1371/journal.pone.0035098)

Zangen DH, Bonner-Weir S, Lee CH, Latimer JB, Miller CP, Habener JF \& Weir GC 1997 Reduced insulin, GLUT2, and IDX-1 in beta-cells after partial pancreatectomy. Diabetes 46 258-264. (https://doi. org/10.2337/diab.46.2.258)

Zhang CY, Baffy G, Perret P, Krauss S, Peroni O, Grujic D, Hagen T, VidalPuig AJ, Boss O, Kim YB, et al. 2001 Uncoupling protein-2 negatively regulates insulin secretion and is a major link between obesity, beta cell dysfunction, and type 2 diabetes. Cell 105 745-755. (https://doi. org/10.1016/S0092-8674(01)00378-6)

Zhang P, McGrath B, Li S, Frank A, Zambito F, Reinert J, Gannon M, Ma K, McNaughton K \& Cavener DR 2002a The PERK eukaryotic initiation factor 2 alpha kinase is required for the development of the http://joe.endocrinology-journals.org

https://doi.org/10.1530/JOE-17-0516 (c) 2018 Society for Endocrinology Published by Bioscientifica Ltd. Printed in Great Britain 
skeletal system, postnatal growth, and the function and viability of the pancreas. Molecular and Cellular Biology 22 3864-3874. (https:// doi.org/10.1128/MCB.22.11.3864-3874.2002)

Zhang W, Khan A, Ostenson CG, Berggren PO, Efendic S \& Meister B 2002b Down-regulated expression of exocytotic proteins in pancreatic islets of diabetic GK rats. Biochemical and Biophysical Research Communications 291 1038-1044. (https://doi.org/10.1006/bbrc.2002.6555)

Zhang C, Moriguchi T, Kajihara M, Esaki R, Harada A, Shimohata H, Oishi H, Hamada M, Morito N, Hasegawa K, et al. 2005 MafA is a key regulator of glucose-stimulated insulin secretion. Molecular and Cellular Biology 25 4969-4976. (https://doi.org/10.1128/MCB.25.12.4969-4976.2005)

Zhang T, Kim DH, Xiao X, Lee S, Gong Z, Muzumdar R, CalabuigNavarro V, Yamauchi J, Harashima H, Wang R, et al. 2016 FoxO1 plays an important role in regulating beta-cell compensation for insulin resistance in male mice. Endocrinology 157 1055-1070. (https://doi. org/10.1210/en.2015-1852)
Zhao C, Wilson MC, Schuit F, Halestrap AP \& Rutter GA 2001 Expression and distribution of lactate/monocarboxylate transporter isoforms in pancreatic islets and the exocrine pancreas. Diabetes 50 361-366. (https://doi.org/10.2337/ diabetes.50.2.361)

Zhao X, Mohan R, Ozcan S \& Tang X 2012 MicroRNA-30d induces insulin transcription factor MafA and insulin production by targeting mitogen-activated protein 4 kinase 4 (MAP4K4) in pancreatic betacells. Journal of Biological Chemistry 287 31155-31164. (https://doi. org/10.1074/jbc.M112.362632)

Zhou YP, Marlen K, Palma JF, Schweitzer A, Reilly L, Gregoire FM, Xu GG, Blume JE \& Johnson JD 2003 Overexpression of repressive cAMP response element modulators in high glucose and fatty acid-treated rat islets A common mechanism for glucose toxicity and lipotoxicity? Journal of Biological Chemistry 278 51316-51323. (https://doi. org/10.1074/jbc.M307972200)

Received in final form 13 November 2017

Accepted 4 December 2017

Accepted Preprint published online 4 December 2017 